\title{
Kernos
}

Revue internationale et pluridisciplinaire de religion grecque antique

$28 \mid 2015$

Varia

\section{Epigraphic Bulletin for Greek Religion 2012 (EBGR 2012)}

Angelos Chaniotis

\section{(2) OpenEdition \\ Journals}

Electronic version

URL: http://journals.openedition.org/kernos/2337

DOI: 10.4000/kernos.2337

ISSN: 2034-7871

\section{Publisher}

Centre international d'étude de la religion grecque antique

Printed version

Date of publication: 1 October 2015

Number of pages: 175-254

ISBN: 978-2-87562-055-2

ISSN: 0776-3824

Electronic reference

Angelos Chaniotis, « Epigraphic Bulletin for Greek Religion 2012 (EBGR 2012) », Kernos [Online], $28 \mid$ 2015, Online since 01 October 2017, connection on 15 September 2020. URL : http:// journals.openedition.org/kernos/2337

This text was automatically generated on 15 September 2020

Kernos 


\title{
Epigraphic Bulletin for Greek Religion 2012 (EBGR 2012)
}

\author{
Angelos Chaniotis
}

125 years ago I took the initiative to create the Epigraphic Bulletin for Greek Religion. Together with Eftychia Stavrianopoulou (EBGR 1990-1991 and 1993/94-1996) and Ioannis Mylonopoulos (EBGR 1996-2005), we have summarized ca. 5,650 epigraphic publications, corpora, and editions of inscriptions, as well as books and articles on Greek religion that heavily rely on the epigraphic evidence. In the most recent issues, I have been placing more emphasis on the presentation of new finds and new readings, restorations, and interpretations rather than on a comprehensive presentation of publications that are dedicated to religious phenomena and adduce inscriptions. I will continue this practice in the future issues, in order to make the timely presentation of new finds possible.

2 The 25th issue of the EBGR presents a selection of epigraphic publications of 2012, with numerous additions to earlier issues (publications of 2006-2011). Publications that could not be considered here, for reasons of space, will be presented in EBGR 2013; they include inter alia two corpora from Asia Minor (S. MITCHELL, D. FRENCH, The Greek and Latin Inscriptions of Ankara [Ancyra]. Volume I. From Augustus to the End of the Third Century AD, Munich, 2012; E. LAFLI, E. CHRISTOF, M. METCALFE, Hadrianopolis I: Inschriften aus Paphlagonia, Oxford, 2012) and an updated edition of the monumental collection of

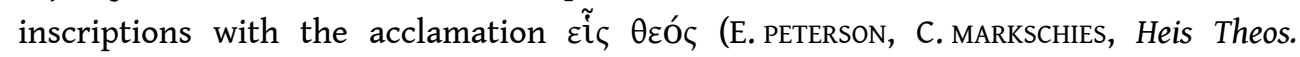
Epigraphische, formgeschichtliche und religionsgeschichtliche Untersuchungen zur antiken "Ein Gott"-Akklamation, Würzburg, 2012). Thanks to the efforts of Professor Klaus Hallof (Berlin), who is co-ordinating the publication of the Inscriptiones Graecae, the oldest project in ancient studies that celebrated its 200th jubilee in August, three new volumes of the IG were published in 2012 and are presented here (Athens: 18 and 105; Kos: 25). This issue also summarizes the content of corpora for Stobi (14) and the Museum of Yozgat (209), a useful collection of Delphic inscriptions (80), and large groups of inscriptions from the Metroion in Dionysopolis (106) and Balboura (127). 
One of the most important texts in this issue is a lead tablet, possibly from Selinous (83), with hexametrical incantations which include an early version of the Ephesia grammata. Among the new inscriptions, I single out a new regulation concerning the sale of the priesthood of Meter Phrygie in Priene (211), an agonistic inscription from Messene (186), a senatus consultum dealing with the limits of sacred land belonging to a sanctuary of Zeus in Melitaia ( $\chi \omega ́ \rho \alpha \Delta$ iò $\varsigma$ OOpuíov, 177), a second copy of a cult regulation from Chios that prohibits the use of groves for pasture (114), a Cretan inscription that attests commemorative anniversaries in Lyttos (98), and a dedication made by Alexander to Ammon, 'his own father' in the Bahariya Oasis (23 bis). New evidence for the cult of Praxidika and Hermes Tychon comes from Dion (147); there is also important evidence for Egyptian cults from Rhodes (65) and Marathon (52).

New inscriptions often add something new to Greek religious vocabulary, such as the

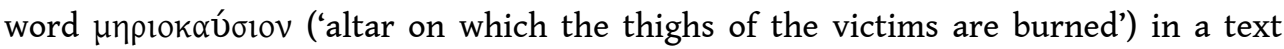
from Asia Minor (55). I also note the expression $\theta \varepsilon o \varphi$ í $\lambda$ ior (3), unusual in a pagan

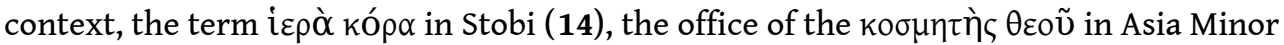
(63; cf. 183), the expression $\Theta \varepsilon \tilde{\omega} \tilde{\eta} \rho \omega \imath$ in an epitaph from the area of Oinoanda (157, also with an unusual representation of the Thracian Rider), and an imaginative funerary imprecation that wishes the individual who opens a grave to incur leprosy or

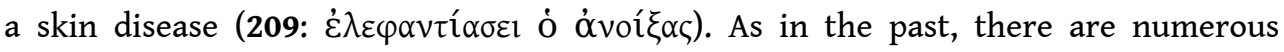
publications concerning magical practices, including an interesting defixio from Messene (187): the defigens invokes chthonic deities and heroes, using a laudatory attribute for Hippolytos ( $\kappa \lambda \varepsilon ı$ ó $)$ ). With regard to rituals, an inscription from Thouria

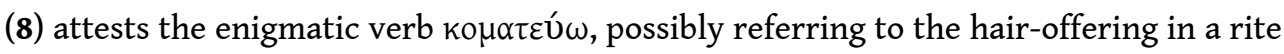
of passage; two inscriptions from Dionysopolis refer to the ritual of $\dot{\alpha} v \theta 0 \lambda$ oүعĩv in honor of Meter Pontie (106). I also note three texts that provide information concerning the funeral of benefactors $(27,67$, and 153$)$.

5 The principles explained in Kernos 4 (1991), p. 287-288, and Kernos 7 (1994), p. 287, also apply to this issue. Abbreviations that are not included in the list are those of L'Année Philologique and J.H.M. STRUBBE (ed.), Supplementum Epigraphicum Graecum. Consolidated Index for Volumes XXXVI-XLV (1986-1995), Amsterdam, 1999, as well as of later volumes of the SEG. If not otherwise specified, dates are BCE. Henry Heitmann-Gordon (University of Munich) has improved the English text.

\section{Abbreviations}

\begin{tabular}{|c|c|}
\hline AEThStE 3 & 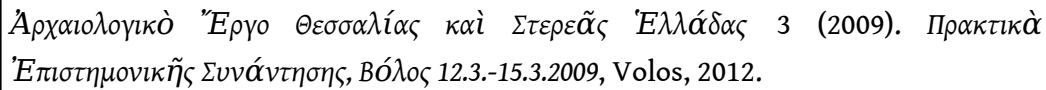 \\
\hline $\begin{array}{l}\text { Ancient Sacral } \\
\text { Monuments }\end{array}$ & $\begin{array}{l}\text { E.K. PETROPOULOS, A.A. MASLENIKOV (eds.), Ancient Sacral Monuments in the Black Sea, } \\
\text { Thessaloniki, } 2010 .\end{array}$ \\
\hline $\begin{array}{l}\text { Bibliotheca Isiaca } \\
\text { II }\end{array}$ & L. BRICAULT, R. VEYMIERS, Bibliotheca Isiaca II, Bordeaux, 2011. \\
\hline $\begin{array}{l}\text { Current } \\
\text { Approaches to } \\
\text { Religion }\end{array}$ & $\begin{array}{l}\text { M. HAYSOM, J. WALLENSTEN (eds.), Current Approaches to Religion in Ancient Greece. } \\
\text { Papers Presented at a Symposium at the Swedish Institute at Athens, 17-19 April 2008, } \\
\text { Stockholm, } 2011 .\end{array}$ \\
\hline
\end{tabular}




\begin{tabular}{|c|c|}
\hline $\begin{array}{l}\text { Des rois au } \\
\text { Prince }\end{array}$ & $\begin{array}{l}\text { I. SAVALLI-LESTRADE, I. COGITORE (eds.), Des rois au Prince. Pratiques du pouvoir } \\
\text { monarchique dans l'Orient hellénistique et romain (IV siècle avant J.-C. - II siècle après J.- } \\
\text { C.), Grenoble, } 2010 .\end{array}$ \\
\hline $\begin{array}{l}\text { Dineessa - } \\
\text { Romiopoulou }\end{array}$ & 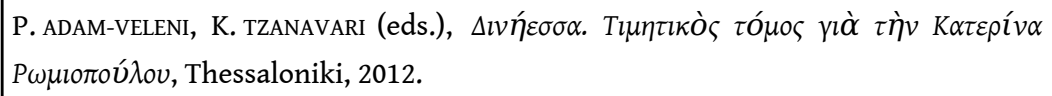 \\
\hline $\begin{array}{l}\text { Early Roman } \\
\text { Thrace }\end{array}$ & $\begin{array}{l}\text { I.P. HAYNES (ed.), Early Roman Thrace: New Evidence from Bulgaria (JRA Suppl. 82), } \\
\text { Portsmouth, RI, 2011. }\end{array}$ \\
\hline $\begin{array}{l}\text { "E } \pi \alpha \text { lvos Luigi } \\
\text { Beschi }\end{array}$ & 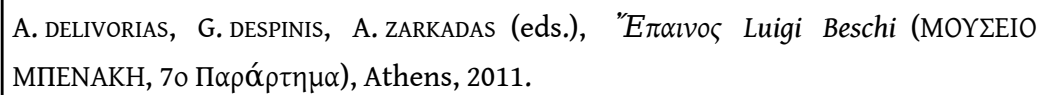 \\
\hline $\begin{array}{l}\text { Individus, } \\
\text { groupes et } \\
\text { politique }\end{array}$ & $\begin{array}{l}\text { J.-C. COUVENHES, S. MILANEZI (eds.), Individus, groupes et politique à Athènes de Solon à } \\
\text { Mithridate. Actes du colloque international. Tour } 7 \text { et } 8 \text { mars 2005, Tours, } 2007 .\end{array}$ \\
\hline $\begin{array}{l}\text { Labraunda and } \\
\text { Karia }\end{array}$ & $\begin{array}{l}\text { L. KARLSSON, S. CARLSSON (eds.), Labraunda and Karia. Proceedings of the International } \\
\text { Symposium Commemorating Sixty Years of Swedish Archaeological Work in Labraunda. } \\
\text { The Royal Swedish Academy of Letters, History and Antiquities, Stockholm November 20- } \\
\text { 21, 2008. Acta Universitatis Upsaliensis (Boreas 32), Uppsala, 2011. }\end{array}$ \\
\hline $\begin{array}{l}\text { More than Men, } \\
\text { Less than Gods }\end{array}$ & $\begin{array}{l}\text { P.P. IOSSIF, A.S. CHANKOWSKI, C.C. LORBER (eds.), More than Men, Less than Gods. Studies } \\
\text { in Royal Cult and Imperial Worship. Proceedings of the International Colloquium } \\
\text { Organized by the Belgian School at Athens (1-2 November 2007), Leuven, } 2011 .\end{array}$ \\
\hline $\begin{array}{l}\text { Namata } \\
\text { Pandermalis }\end{array}$ & 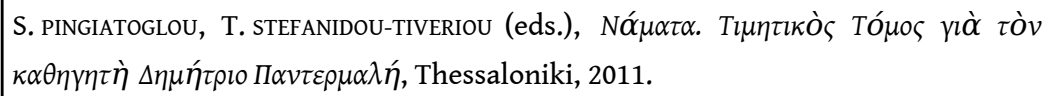 \\
\hline $\begin{array}{l}\text { Omaggio } \\
\text { Lombardi }\end{array}$ & 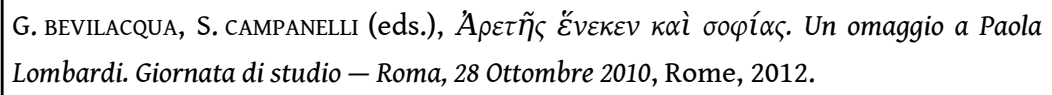 \\
\hline One God & $\begin{array}{l}\text { S. MITCHELL, P. VAN NUFFELEN (eds.), One God: Pagan Monotheism in the Roman Empire, } \\
\text { Cambridge, } 2010 .\end{array}$ \\
\hline Onomatologos & $\begin{array}{l}\text { R.W.V. CATLING, F. MARCHAND (eds.), Onomatologos: Studies in Greek Personal Names } \\
\text { Presented to Elaine Matthews, Oxford, } 2010 .\end{array}$ \\
\hline Spazio ionico & $\begin{array}{l}\text { C. ANTONETTI (ed.), Lo spazio ionico e le comunità della Grecia nord-occidentale. } \\
\text { Territorio, società, istituzioni, Pisa, } 2010 \text {. }\end{array}$ \\
\hline Studies - Tracy & $\begin{array}{l}\text { G. REGER, F.X. RYAN, T.F. WINTERS (eds.), Studies in Greek Epigraphy and History in } \\
\text { Honor of Stephen V. Tracy, Bordeaux, } 2010 \text {. }\end{array}$ \\
\hline Symposion 2009 & $\begin{array}{l}\text { G. THÜR (ed.), Symposion 2009. Vorträge zur griechischen und hellenistischen } \\
\text { Rechtsgeschichte (Seggau, 25-30. August 2009), Vienna, 2010. }\end{array}$ \\
\hline $\begin{array}{l}\text { Unveiling } \\
\text { Emotions }\end{array}$ & $\begin{array}{l}\text { A. CHANIOTIS (ed.), Unveiling Emotions: Sources and Methods for the Study of Emotions in } \\
\text { the Greek World, Stuttgart, } 2012 \text {. }\end{array}$ \\
\hline
\end{tabular}




\section{Selected Topics}

\section{Geographical areas (in the sequence adopted by $S E G$ )}

Attica: Athens: 11. 18. 27. 50. 89. 90. 94. 105. 107. 112. 113. 122. 141. 145. 168. 172. 180. 195. 196. 205. 212; Brauron: 141; Eleusis: 145. 168. 175; Marathon: 52; Piraeus: 116. Peloponnese: Aigina: 175. Argolis: Agos: 180. 201; Lerna: 175. Epidauria: Epidauros: 42. 117. 174. Lakonia: Sparta: 191. Messenia: 7; Andania: 70; Messene: 67. 170. 184-187; Thouria: 6. 8. Arkadia: Lousoi: 22; Lykosoura: 84; Mantineia: 144; Megalopolis: 180. Elis: Olympia: 73. Boiotia: 97; Chaironeia: 110; Hyettos: 88; Koroneia: 23. 97; Lebadeia: 23; Onchestos: 97; Orchomenos: 23. 110; Oropos: 145; Tanagra: 174; Thebes: 110; Thespiai: 174. Delphi: 80. 90. 109. Doris: 158. Phokis: Boulis: 158; Hyampolis: 73; Tithorea: 159. Eastern Lokris: Daphnous: 143. Akarnania: 5. 15. 16; Astakos: 180; Palairos: 180; Thyrrheion: 15. Ionian Islands: 5. Korkyra: 15. 125. Thessaly: 51. 97. 123. 169; Azoros: 193; Demetrias: 32. 189; Doliche: 56. 194; Lamia: 18; Melitaia: 177; Pharsalos: 207; Pherai: 58. 142; Trikke: 27. Epeiros: 5. 15. 16; Ambrakia: 15. Illyria: 5. Dalmatia: Rhizon: 103. Macedonia: 13. 43. 137; Aigai: 161; Amphipolis: 93. 164; Dion: 45. 147; Edessa: 206; Kalindoia: 150; Philippi: 32. 135; Pydna: 190; Stobi: 14. Thrace: 46. 146. 171; Byzantion: 73; Dionysopolis: 106; Odessos: 126. Moesia: 119. 121. 146; Durostorum: 62; Histria: 26; Nikopolis ad Istrum: 140; Tomis: 17. 120. North Shore of the Black Sea: 21. 95. 138. 146; Olbia: 95. 96. 160; Pantikapaion: 166. 192; Tanais: 78. Delos: 68. 124. 162. Rhodes: 65. Lesbos: Mytilene: 44. Peparethos: 59. Kos: 24. 35. 36. Chios: 114. Samos: 108. Lemnos: 155. Euboia: 10; Chalkis: 174. Crete: Chersonesos: 98; Lyttos: 98; Olous: 98. Sicily: Selinous: 83; Syracuse: 142; Tauromenion: 132. Italy: 151; Bologna: 165; Centuriapae: 115; Kyme: 86; Lanuvium: 115; Lokroi Epizephyrioi: 53. 54; Rome: 151. 175. Spain: Celti: 178; Tarraco: 99. Asia Minor: Karia: 69; Amyzon: 167; Aphrodisias: 41; Attouda: 41; Euromos: 167; Halikarnassos: 77; Iasos: 210; Knidos: 40. 162; Labraunda: 76; Mylasa: 57. 167. 203; Stratonikeia: 197. Ionia: Didyma: 71. 72; Ephesos: 34. 89. 152. 181; Magnesia on the Maeander: 110; Miletos: 72; Priene: 85. 176. 211; Teos: 80. 210; Smyrna: 1. 80. Lydia: 152; Iulia Gordos: 153; Sardeis: 148. 210. Troas: Alexandria Troas: 162; Assos: 108; Ilion: 92. Mysia: 18. 182; Hadrianoi: 4. 55. 82; Kyzikos: 49. 80; Pergamon: 80. 89. 131. 179. Bithynia: Kalchedon: 80; Nikaia: 46. Pontos: 209; Amisos: 138. Paphlagonia: Phazimon: 108. Galatia: Tavium: 209. Phrygia: 3; Aizanoi: 82; Akmonia: 188; Hierapolis: 154; Apameia/Kelainai: 29; Kole: 60. Pisidia: 2. 101; Anaboura: 100; Apollonia Mordiaon: 102; Konane: 79; Sagalassos: 129. Lykia: Balboura: 127; Kaunos: 157; Kibyra: 48; Patara: 63; Termessos Minor: 157; Tlos: 157; Xanthos: 157. 167. 183. Kappadokia: 209. Cyprus: 108; Amathous: 19. 66; Kafizin: 81. Bactria: 61. 198. Syria: Apameia: 64; Byblos: 31; Daphne: 18; Zeugma: 64. Egypt: 23 bis. 74; Alexandria: 162. Kyrene: 32.156

acclamation: 3. 20. 39. 40. 129. 181. 202; see also Greek words

accounts: 195

9 aesthetic aspects in cult: 105

10 afterlife: 29. 91. 213; see also s.v. underworld

11 agermos: 211

12 agonistic festival: 105; of Chrysaoreis: 69; Agrippeia 24 (Kos); Aktia 24. 99; Aleiaia 186 (Tegea); Apollonia 174 (Epidauros). 24 (Myndos); Apollonia Pythia 154; Archegesia 24 (Halikarnassos); Asklepieia 174 (Epidauros). 24 (Kos); Aspis 24 (Argos); Attaleia 80 
(Delphi); Basileia 186 (Lebadeia); Chrysanthinos Agon 148 (Sardis); Delia 186 (Tanagra); Demetrieia 174 (Chalkis); Dionysia 18. 105 (Athens). 174 (Chalkis). 24 (Kos, Teos); Doreia 24 (Knidos); Eleusinia 18. 24; Eleutheria 186 (Larisa). 18. 80. 186 (Plataia); Eleutheria Kaisareia 24; Eumeneia 80 (Delphi, Sardis); Hadrianeia 173; Halieia 186 (Rhodes); Hekatesia 24 (Stratonikeia); Hephaisteia 195 (Athens); Heraia 186; Herakleia 24 (Iasos); Isthmia 24. 186; Kaisareia 102 (Apollonia Mordiaon). 24 (Halikarnassos, Kos, Metropolis, Patrai, Sardes); Kapitolia 24; Klaria 24; Klaudeia 24 (Rhodes); Koinos Asias 24. 148; Koinos Ionon 24; Koinos Makedonon 24; Koinos Thessalon 24; Kornouteia 102; Leukophryena 18; Lykaia 18. 24. 186; Mouseia 174 (Thespiai); Nemea 24. 99. 105. 186; Nemesia 18; Nikephoria 80 (Pergamon); Olympia 24. 52 (Alexandria). 181 (Ephesos). 186; Panathenaia 92 (Ilion). 8. 24. 105. 145. 172. 173. 186 (Athens); Panhellenia 173; Ptolemaia 18. 80; Pythia 80. 186 (Delphi). 186 (Megara); Rhomaia 24 (Kos, Pergamon). 186 (Aigion, Chalkis, Messene); Sarapieia 174 (Tanagra); Sebasta 24 (Neapolis); Soteria 80 (Delphi); Theogamia 24 (Nysa); Traianeia Diiphilia 131

agonistic festival: musicians in: 174; hieronikai: 106; prizes: 149

Alexander the Great: 23 bis

altar: 4. 24. 46. 55. 82. 102. 106. 121 ; funerary: 157 ; funerary altar jointly dedicated to god and deceased individual: 4

amphiktyony: Chrysaoreis: 69; Delphi: 80. 110; Ilion: 92

amulet: 62. 202; see also s.v. phylactery

anatomical votive: 65

ancestral cult: 63

angel: 39. 82. 128

aniconic worship: 128

animal: dog: 1; eagle: 128

ant: 140

apotropaic text: 54

aretalogy: 40.68. 118

association, cult: 5. 12.14. 24. 81. 101. 106. 135

asylia: 22.42 .80

banquet: 15. 24. 81. 105. 106. 127. 144; banquet hall: 143

bench: 106.126

benefactor: 24 . 63. 88. 127.144; cult of: 67

birthday: 24

cake, sacrificial: 211

calendar: 167.194

cave, cult: 81.158 .207

childhood: 142

chorus: 98

confession inscription: 40

Christians: 29. 129; destruction of inscription by C.: 41 
chthonic cult: 147

commemorative anniversary: 98

competition: 20 ; between demes for a cult: 24

consolation: 102

cry, ritual: 94

crypt: 185

cult, of gentilician group: 24; of mortal: 67 (benefactor). 76 (Olympichos); 80 (Memmius Nikandros). 102. 157. 172 (tyrannicides); see also s.vv. cave cult, chthonic cult, deme cult, hero cult, imperial cult, ruler cult

cult, expenses: 63. 105. 125; foundation of cult: 35; funded through taxation: 50; introduction of: 68. 105. 110. 126. 142. 167; participation in: 80; reform: 70

cult personnel: agonothetes 24. 92. 102. 149. 181. 184; aozos 15. 16; archeuon: 24; archiereia 188; of imperial cult in a city: 206; of Asia: 179; archiereus of Asia: 179; of Lykia: 63; archiereus of civic cult: 14. 24. 126. 184; archiereus of Seleucid ruler cult: 167; architheoros: 105; auletes 15; Bithyniarches: 55; chrysophoros 55; diakonos 15; epimeletes pompes 18; hestia 15; hestiarchos 15; hierapolos 15. 180; hiereia 1. 18. 24. 48. 80. 106. 127. 129. 144. 152. 206. 211; hiereus 18. 24. 32. 56. 60. 63. 93. 102. 105. 106. 127. 156. 180; hierodoulos 24. 106; hierokeryx 24; hieromnemon 18. 69; hieronomos 106; hierophoros 15. 16. 24; hierophylax 24; hieropoioi 24. 105; hieros 192; hierothytes 6. 15; hydrophoros 72; hyperetes 15; kanephoros 18; kosmetes 63. 183; Lykiarches 63; mageiros 15; mantis 15; neokoros 24. 52. 56; neopoios 24. 152; oinochoos 15; panegyriarchos/es 24. 152; prophetis 72; spondophoros: 18; synestai 15; theophoros 106; thoinarmostria: 187; see also s.v. priest, priesthood

cult personnel: hereditary: 24. 102; selected by god: 72

cult regulation: 18. 24. 38. 40. 42.51. 53. 55. 70. 80. 84. 105. 114. 151. 168. 211

curse: 40.113. 147; see also s.vv. defixio, funerary imprecation, prayer for justice

curse tablet: see s.v. defixio

dance: 142

death: 102.176 ; caused by god: 11 ; caused by fate: 176 ; consolation: 27 ; metaphor for d.: 102. 153; see also s.v. afterlife

decoration: 105

dedication, motives for: after healing: 24 ; after trade trip: 45; after victory in war: 109; divine command: 3 . 24. 55. 79; gratitude: 24, 49. 182; piety: 52; protection of agricultural production: 3; protection of the household: 3; protection of a village: 3; summa honoraria: 137; well-being of emperors: 24; well-being of family members: 3 . 24. 58. 142. 182; well-being of a king/queen: 47. 78; well-being of a master: 46. 101; well-being of a statesman: 24; see also s.v. vow; see also Greek words

dedication, agent of: magistrate: 24.137 ; priest/priestess: 1. 102. 106. 127. 129. 156. 180; priest after exit from service: 24. 56; slave: 14; soldier: 24. 34. 103. 120; winner in contest: 24

dedication, object of: dekate: 71 ; loomweight: 94 ; statue of a relative: 8 . 71. 141; war booty: 73; see also s.v. anatomical votive, ears, footprint, tithe, trophy

dedication: joint d. to Apollo and Artemis: 208; joint d. to god and a deceased individual: 3; label on d: 158; melting down of: 18; re-used as grave offering: 196 

145. Aphrodite: 14. 23. 24. 48. 96. 98. 105. 180. 189; Epiteleia: 80; Limenarchis: 170; Olbie: 96; Pontia: 24; Stratonikis 80. Apollo: 10. 18. 24. 63. 72. 78. 80. 83. 100. 123. 126. 146. 156. 157. 160. 208; Aiginaios: 160; Dalios: 24; Delphinios: 126; Didymeus: 24. 71; Kalymnas medeon: 24; Karneios: 24; Klarios: 14; Lykeios: 18. 50; Phoibos: 100; Prostaterios: 18; Pythios: 24. 80. 98. 122. 193; Soter: 24. 102. Ares: 18. 23. 30. 98. 105. 127. Artemis: 14. 22. 24. 36. 98. 152.157. 160. 177. 180. 181. 184. 208; Akraia: 43; Blaganitis: 43; Bloireitis: 43; Boulaia: 18; Brauronia: 105; Digaia: 43; Ephesie: 160; Gazoria: 43; Gourasia: 43; Mounychia: 105. 141; Pergaia: 24; Pheraia: 142; Phosphoros: 18; Pythie: 72; Sibonnike: 43; Soteira: 186; Toxitis: 24. Asklepios: 6. 8. 14. 18. 24. 42. 59. 105. 117. 137. 143. 177. 179. Aspalis: 177. Athena: 18. 24. 98. 105. 106. 112. 126. 145. 180. 189; Alalkomenia: 97; Alseia: 24; Archegetis: 18; Athenon medeousa: 24; Ergane: 80; Hephastia: 105; Ilias: 92; Itonia: 80. 97. 105; Nike: 105; Nikephoros: 18. 80; Phatria: 24; Polias: 24; Skiras 94; Soteira: 105; Zosteria: 80. Boras: 177. Britomartis: 98 (Britomarpis). Charites: 18. 24. Demeter: 1. 18. 24. 83. 105. 153. 160. 175. 177. 187; Homaria: 10; Karpophoros: 24; Lemnia: 10; Soteira: 24; Thesmophoros: 153. Demokratia: 18. Demos: 18. Despoina: 84. 170. Diktynna: 167. Dionysos: 14. 24. 58. 98. 105. 106. 110. 116. 127. 160. 175. 184. 206; Kadmeios: 110; Phleos: 211; Sphaleotas: 80. Dioskouroi: 2. 160. 191. Dodeka Theoi: 24. 105. Eirene: 24. Eileithyia: 80. 184. 186. Ennodia: 142. 177. Epione: 24. Eros: 191. Euteria: 24. Ge: 105. Hekate: 2. 21. 83. 171. 175. 186; Soteira: 24; Stratia: 24. Helios: 2. 18. 24. 105. 106. Hephaistos: 105. 195. Hera: 86. 98. 180; Argeia: 24; Basileia: 24; Dirphia: 10; Olympia: 24; Ourania: 24. Herakles: 14. 24. 35. 106. 124. 126. 127. 132. 175. 186; Kynagidas: 56; Patroios: 161. Hermes: 18. 24. 98. 124. 132. 147. 157. 160. 171. 189. 211; Kyllanios: 24; Tychon: 147. Hestia: 98; Phamia: 24. Homonoia: 24. Horai: 18. Hygieia: 8. 14. 24. 80. 137. Ino: 177. Kephisos: 205. Keres: 186. Kore: 24. 105. 160. 185. 187; Soteira: 80. Kouretes: 98. Kybele: 85. 175. 211. Leto: 24. 98. 157. 183. 208. Merops: 24. Meter: 160; Adrastou: 41; Phrygie: 211. Meter Theon: 1. 64. 85. 189; Lykochoritike 4; Pontia: 106. Moirai: 24. Muses: 24. Nemesis: 14. Nike: 23. 24. Nymph: 81. Nymphs: 14. 17. 24. 98. 126. 158. 176. 207. Pan: 24. 158. 211. Parthenos: 13. Persephone: 83. 119 ? Plouton: 119? Poseidon: 24. 97. 98. 105. 126. 160. 177; Asphaleios: 24. 170; Asphaleus: 106; Geraistios: 24; Helikonios: 211; Nauklarios: 124; Pelagios: 105. Praxidika: 147. Priapos: 147. Rhea: 24. Selene: 2. 190. Telesphoros: 14. Thea Rhome: 126. 131. 150. 157. Theai: Hagnai: 129; Semnai: 18. Themis: 194. Theoi: Patrioi: 36. 120; Patroioi: 24. Theos: Hypsistos: 128. Tyche Agathe: 24. Tychon: 147. Zeus: 53. 80. 102. 128. 140. 150. 157. 177. 189. 211; Alseios: 24; Anabatenos: 82; Bronton: 3; Chrysaoreus: 69; Epidotas: 186; Epopsios: 24; Heliopolites: 101; Hikesios: 24. 36; Hypsistos: 24. Idaios: 98; Ithomatas: 184; Kasios: 47; Kretagenes: 98. 167; Ktesios: 18; Machaneus: 24; Monnitios: 98; Nikator: 101; Olbios: 49; Olympios: 24. 77. 82. 105; Othryios: 177; Ourios: 124; Patroios: 24; Philios: 127. 131; Polieus: 24; Soter: 105. 160; Soterios: 177; Tallaios: 98

61 deities, Anatolian: Angdistis 129; Attis 106; Basileus of Kaunos 24; Hosios Dikaios 4; Hosios kai Dikaios 4. 82; Kakasbos 157; Tadenos 46; Thea Peismatene 182; Theoi Pisidikoi 2; Zeus Anabatenos 4; Galaktenos 79. 101; Kersoullos: 82; Kraouandaseon 28; Limnenos 3; Okonenos 4 deities, Dalmatian: Medauros: 103 deities, Egyptian: 16. 24. 30. 31. 32. 34. 45. 52. 65. 68. 124. 151. 164. 175. 201. 202; Ammon: 105; Anoubis: 164; Hermanoubis: 30. 45; Isis 14. 118. 185; Osiris 65; Sarapis: 12. 159. 164. 201. 202 
deities, Iranian deities: Mes: 79

deities, Oriental deities: Belos: 24; Mithras: 126. 175; Oxos: 61. 198; Parthenos 13; Sabazios: 23. 41

deities, Roman: Concordia 126; Iuppiter Capitolinus 186; Iuppiter Optimus Maximus 14. 135; Liber Pater 14; Mars 126; Minerva 24; Silvanus 126; Sol Invictus 126; Ultrix Augusta 14

deities, Thracian: Daimones Antanoi 14; Darzalas 126; Heros Karabasmos 126; Heros Manibazos 120; Heros Phylax 106; Thracian Rider: 25. 106. 158

deity, concept of: 20. 39. 117; council of gods: 39; dedicates statue of other deity: 82; emotions towards d.: 40; epithets: 40; epithets denoting separate hypostases: 82; hierarchy: 39; mediator between mortals and d.: 25; mortals compared with gods: 29; named after cult founder: 41; naming fortifications: 24 ; patron of birth: 80 ; patron of child: 205; patron of city: 39; patron of fertility: 45. 147; patron of justice: 147; patron of trade: 45 ; patron of travelers: 100; presence: 39 ; purity: 106; serving as priest: 106; superiority: 20; see also s.v. river god, snake god

deme cult: 24

disease, perceived as punishment: 42. 209

divination: 18.80 .86

Dionysiac technitai: 80. 93?. 107. 149

Dodekais: 80

donations, collection of: 211

dream: 151

dress: see s.v. garments

eagle: 128

ears: 13.45 .189

earthquake: 24

elite: 80

emotion: 29. 40.117.118. 162

encomium: 24

endowment, for cult: 36; for festival: 106; funerary: 63.135

enthronization: 18

ephebes: 18.24 .27

Ephesia grammata: 54.83

epithet, construction of: 39

eschatology: 213

evil eye: 24

fear of gods: 40

festival: 5. 18. 24. 80. 106. 107; endowment for: 106. 125; exemption from taxes: 131; expenses: 174; finances: 174; invitation of allied city: 98; performance (acrobatic) by a pig: 206; periodicity: 92; re-organization: 80 ; see also s.v. commemorative anniversary; see also Greek words (celebration, festival) 

emperor identified with god 24 (Agrippina-Demeter, Augustus-Apollo, Augustus-Zeus, Caligula-Asklepios, Claudius-Apollo, Claudius-Zeus, Drusilla-Aphrodite, DrusillaHomonoia, Iulia-Leto, Nero-Asklepios, Tiberius-Zeus). 77 (Hadrian-Zeus olympios, Sabina-Hera). 89 (Augustus-Apollo); era connected with emperor: 24; funded through fines: 41
inauguration: 211

incantation: 54.83 106; Oschophoria 94; Proerosia 18; Pythais 80. 90; Thargel 24; Thiodaisia 98

finances of cult: 24.70 .105 .125 .131 .145 .174

flower, collection: 106

flutist: 106

food offering: 211

footprints: 14.45

founder, city: 115

funeral: 27.67.102.153

funerary cult: 3.4 .14 .18 .25 .57 .63 .67 .127 .135 .209 ; see also s.v. grave monument

funerary imprecation: 2. 29. 63. 127. 153. 157. 209

garments: 55.70 .84

gem: 202

god-fearers: 128

grave monument: 63; intra muros: 67

grove: 63.114

gymnasion: 24.132

hair offering: 7

healing god: 151

healing miracle: 117

hero, descent from: 24

hero cult: 21?. 24. 90. 157; Achilles: 138. 160; Aias: 18; Amphiaraos: 11; Hippolytos: 186; Iatros: 18; tyrannicides: 172; heroization: 24

historiola: 83

Homer: 26

hope in religion: 40.117

humans, origin of: 100

hymn: 39.80

identity: 90.97

image, divine, carried: 16

imperial cult: 14. 19. 24. 41. 44. 60. 63. 66. 77. 80. 89.111. 126.127. 131. 150. 179. 184. 204; emperor identified with god 24 (Agrippina-Demeter, Augustus-Apollo, Augustus-Zeus, 
inventory: 112

Jews: 14.29

lamp: 1.52

loomweight: 94

maenad: 110

'new' god: 77

pelanos: 80

phallagogia: 206

incubation: 143.151

incense burner: 18 (libanotis). 24

initiation, initiate: 110.118 .175 .211

invocation: 3. 81. 159. 202

kinship, mythological: 115

land, sacred: 24. 145. 105. 177

lex sacra: see s.v. cult regulation

libation: 21.84 .172

magic: 33. 54. 83. 84; magical figure: 165; magical signs: 165; magical words: 165; see also s.vv. amulet, apotropaic text, Ephesia grammata, gem, incantation, phylactery

manumission, sacred: 5.80.155. 159

migration and religion: 126

miracle: 24 . 185; healing m.: 117; narrative of m.: 40.117

monotheism: 20.39 .128

morality in religion: 42

music in cult: 174

mystery cult: 18.24 .70 .84 .168 ; morality and initiation: 42 ; multiple initiation: 175

myth: 26; 80 (Agamemnon). 97. 115. 140. 169. 186. 191

name, deriving from festival: 136; inspired by myth: 169; theophoric: 139

Neoplatonists: 175

nympholepsy: 81

oath: 40; of loyalty: 108; treaty: 98.105

olive, sacred: 145

oracle: 14.18 .23 .39 .40 .72 .80 .110 ; belief in: 11 ; theosophical: 39

Orphics: 91. 190. 192; Dionysiac-Orphic tablets: 83

paganism in Late Antiquity: 175

Panhellenion: 27. 77

personification: Demokratia: 18; Eueteria: 24; Homonoia: 24

phylactery: 33; see also s.v. amulet

piety: 39. 40.52. 81; see also Greek words 
politics and religion: 12.80

pollution, development of concept: 42

prayer: 24. 29.58. 80; addressed to heroized mortal: 80; prayer for justisce: 42. 162. 200

priesthood, accumulation of offices: 14.24 .127 ; board of priests: 93.180 ; couple serving as priests: 14.127 ; god serving as p.: 106; honorific statue of: 80 ; iteration: 60 ; list of p.: 106; purity of: 14; sale of priesthood: 211; serving for 60 years: 14; serving for life: 24.72.

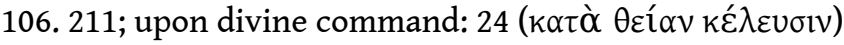

priest: see s.v. cult personnel (hiereia, hiereus)

procession: 18. 70. 105. 106. 206; propompeia: 18

promanteia: 80

propitiation: 106

protective text: 83

punishment, divine: 24.40 .162

purification: 85

purity: 38.42 .84 .106 .127 .151

Pythais: 80. 90.105

rite of passage: 8.142

ritual, efficacy of: 42; joint ritual activity: 5; transformation of r.: 42; see also s.vv. agermos, banquet, Dodekais, enthronization, flower (collection), funeral, hair offering, inauguration, incubation, initiation, libation, oath, prayer, procession, purification, Pythais, rite of passage, rosalia, sacrifice, staging, wedding; see also Greek words

river god: 61.205

Roman influence: 135.136

rosalia: 135

ruler cult: 18.23 bis. 24.34 .66 .76 .74 .101 .167 .210 ; Arsinoe II: 66; Laodike IV: 210; association of ruler cult with cult of gods: 34.101

sacred money, used for dedication: 82

sacrifice: 16 . 18. 24 . 38 . 80. 81. 84. 98. 105. 211; bloodless: 211 ; commemorative: 80 ; offered by magistrates: 18; perquisites of priest: 211

sacrilege: 160

sanctuary: 24. 105. 203; behavior in: 86; building works in: 80; control of: 177; domestic: 95; exploitation of: 116; fine paid to s.: 159; sacred money used for constructions: 80; order in: 55; ownership of land: 80; ownership of livestock: 80; philosophical text in s.: 100; prohibited objects in s.: 84; protection of: 114; recipient of fine: 41 ; see also s.vv. account, inventory, land (sacred), temple

simplicity: 84

slave, assigned to funerary cult: 63 ; sacred: 24.63 .106 .127 .203

snake-god: 25

society: 90

soul: 91 ; immortality: 29

staging in cult: 118 
statue, cult: 134. 195; of emperor: 87. 131; of god: 14. 24. 102.106. 127. 170; carried in procession: 106. 110; dedicated to god: 24.73 .88 .161 . 183. 187; discovery of: 24.110 ; placed near grave: 4; restoration: 105

Stoics: 100

superstition: 84

table, cult: 24.106 .159

temple: 134; bars for statues: 134; opening of: 134; wooden: 157

theater: 110

theorodokos: 18.80

theosebeis: 128

tithe: 81

treasure: 6.24

tree, cutting of: 24

Trophonios: 23

trophy: 23

youth: 8

underworld: 91

victory, attributed to god: 11

vow: 1. 3. 4. 13. 24. 28. 46. 61. 64. 79. 157. 182

wedding: 35

wine, prohibition against: 80

women: 5. 14. 24. 110. 142. 211; unmarried: 72

\section{Greek words (a selection)}

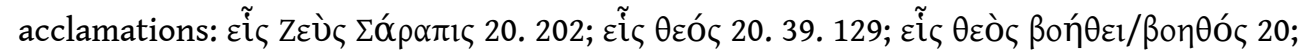

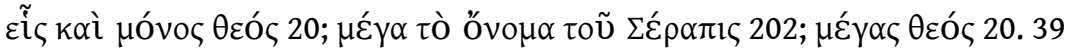

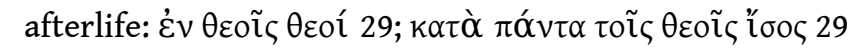

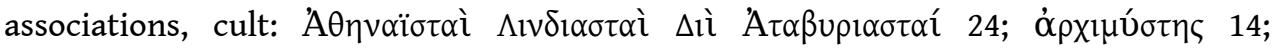

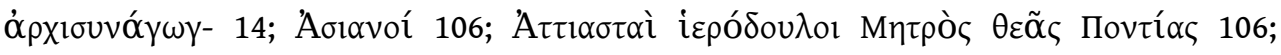

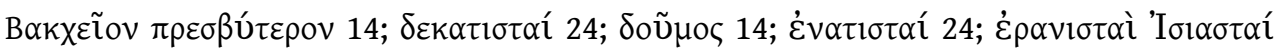

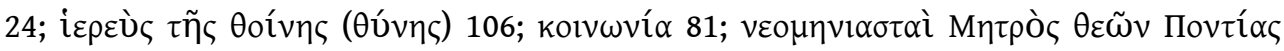

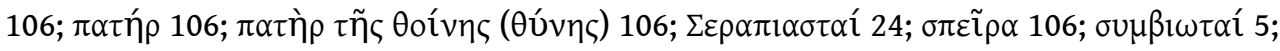

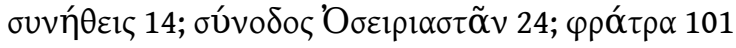

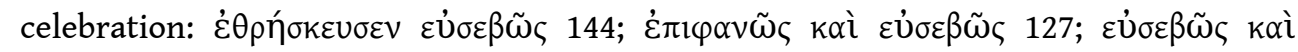

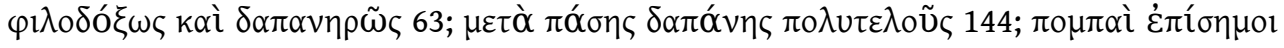
106; $\dot{\omega} \varsigma \kappa \alpha \lambda \lambda i ́ \sigma \tau \eta 105$

cult cry: $\dot{\varepsilon} \lambda \eta \lambda \varepsilon u ́$, ioú, ioú 94

cult foundation: $\sigma u v \kappa \alpha \theta_{1 \varepsilon \rho o ́ \omega} 24$

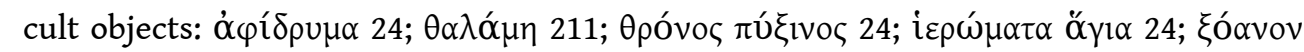

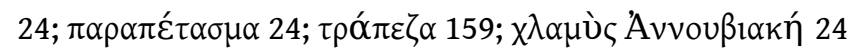




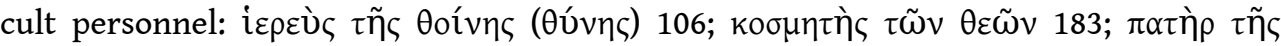

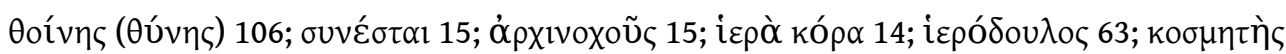

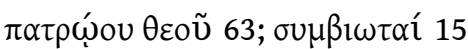

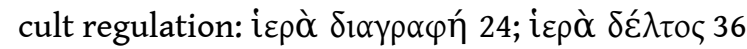

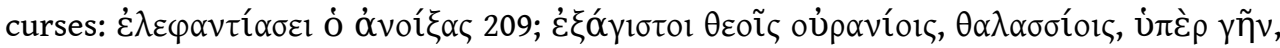

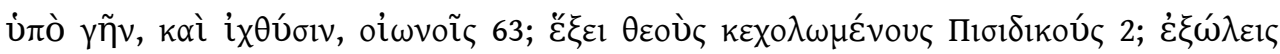

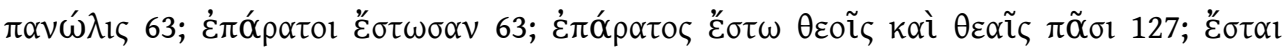

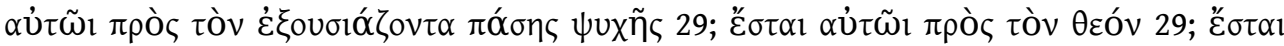

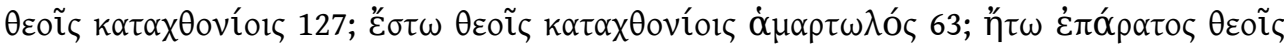

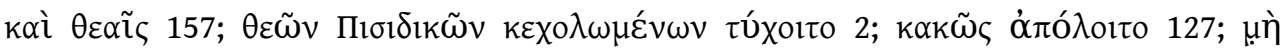

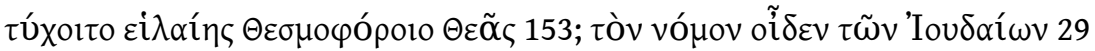

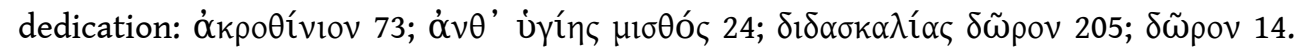

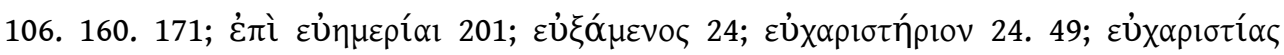

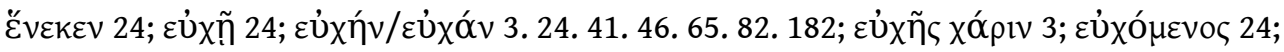

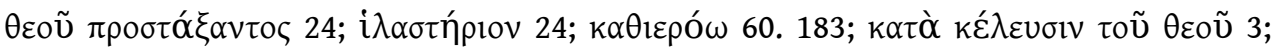

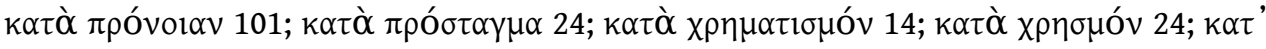

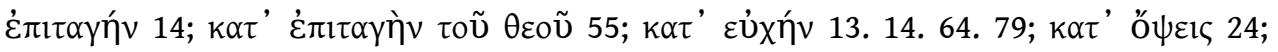

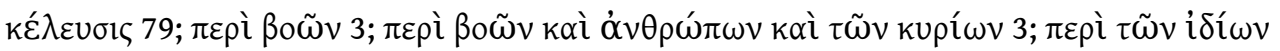

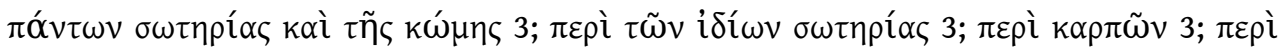

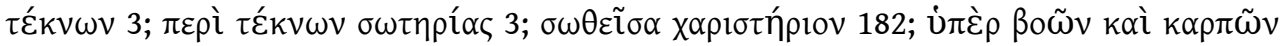

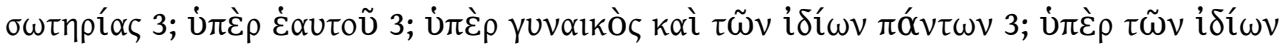

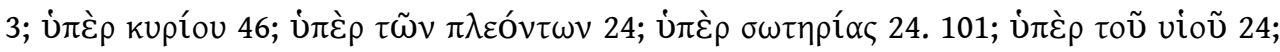

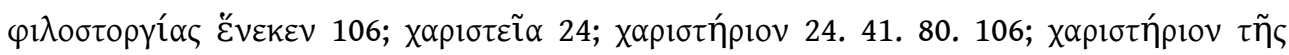

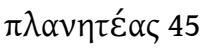

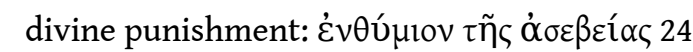

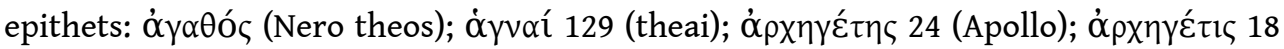

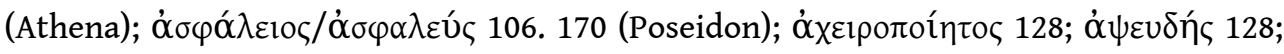

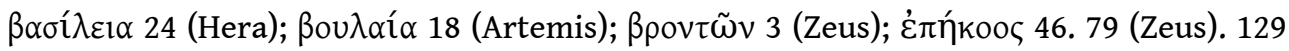

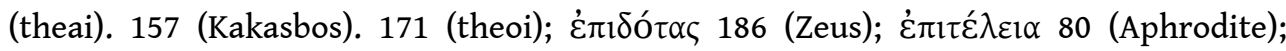
غ̇лó

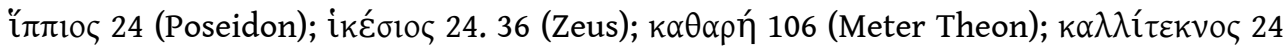

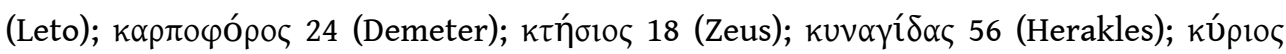

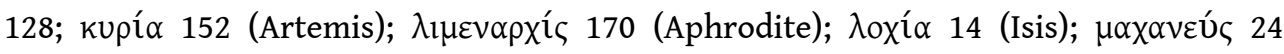
(Zeus); $\mu \varepsilon ́ \gamma \alpha \varsigma 24$ (theoi). 126 (Darzalas); $\mu \varepsilon \delta \varepsilon ́ o v \sigma \alpha 24$ (Athena); $\mu \varepsilon \delta \varepsilon ́ \omega v 24$ (Apollo);

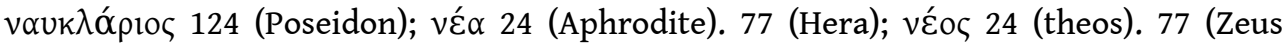

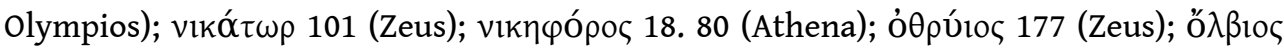

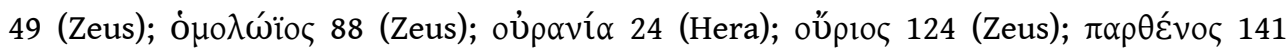

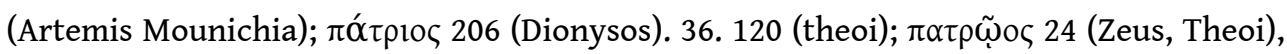

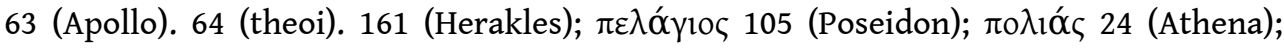

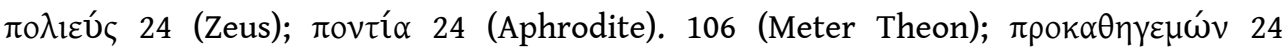

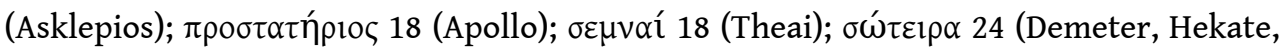
Isis). 24. 80 (Kore). (Athena). 186 (Artemis); $\sigma \omega \tau \eta ́ p ~ 24$ (Asklepios). 24. 102 (Apollo). 24

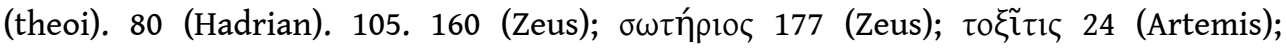

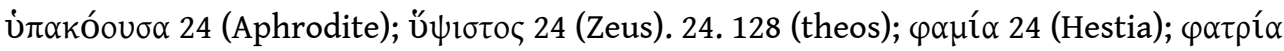




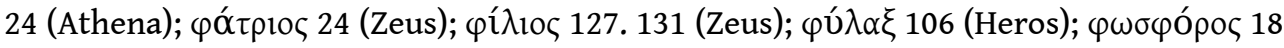
(Artemis)

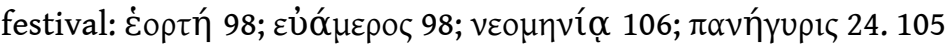

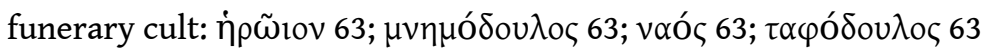

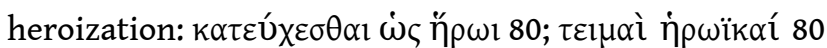

initiation: $\tau \varepsilon \lambda \varepsilon ́ \omega 211$

magic: $A \beta \rho \alpha \sigma \alpha \xi 62.202 ;$ ' $\mathrm{\top} \alpha \omega 62$

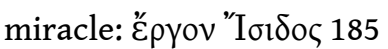

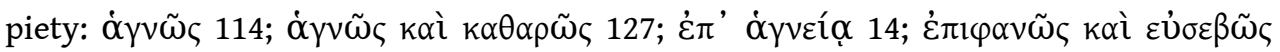

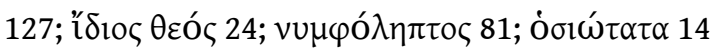

purification: $\kappa \alpha \theta \alpha \rho \mu$ òv $\kappa \alpha \theta \alpha i ́ \rho \omega 85$

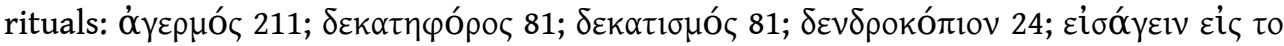

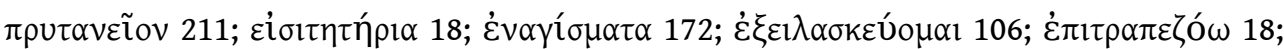

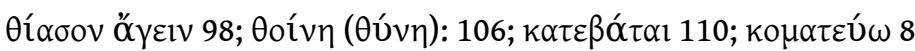

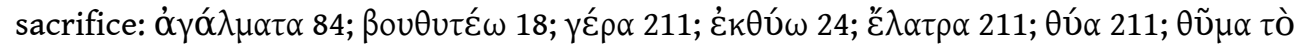

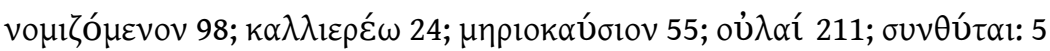

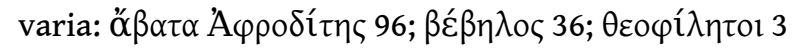

1) D. AKAR TANRIVER, "Two Bronze Objects with Dedicatory Inscriptions in the Izmir Museum", EA 45 (2012), p. 101-102 [BE 2013, 53]: Ed. pr. of two dedications of unknown provenance in the Izmir Museum (probably from Smyrna or its vicinity). 1) A bronze cast lamp; the filling hole has a lid in the form of a scallop shell with a flame guard in the form of an ivy leaf; a dedicatory inscription was incised on the leaf. The lamp was dedicated by Demetria, a priestess of Demeter (1st/2nd cent.). 2) A cast statuette of a standing dog. According to an inscription incised on the right side of the dog the object was dedicated by Louki(o)s to the Meter Theon in fulfillment of a vow (2nd cent. CE).

2) E. AKINCI ÖZTÜRK, H. MALAY, "Four Funerary Curses Recording the Pisidian Gods of the Acipayam Plain", EA 45 (2012), p. 89-92 [BE 2013, 408]: Ed. pr. of four epitaphs from Dodurgala in the Acipayam Plain (near the ancient cities of Eriza and Themisonion, Imperial period). The graves are protected with funerary imprecations that invoke the

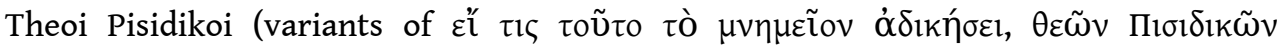

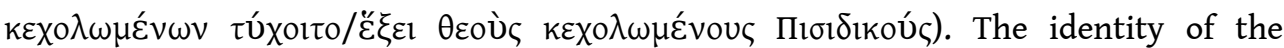
Pisidian gods is unknown (Selene/Hekate, Helios, possibly the Dioskouroi).

3) N.E. AKYÜREK §̧AHIN, "Phrygia'dan yeni Zeus Bronton Adaklari”, Arkeoloji ve Sanat 122 (2006), p. 89-124: Ed. pr. of 60 new inscribed dedications to Zeus Bronton, an important weather and fertility god (north Phrygia, Imperial period). Some of the dedications (stelai and altars) had relief decoration (crown, eagle, bust, bucranium, etc.). Many monuments come from a major sanctuary near Yazidere ( $\left.n^{\text {os }} 34-57\right)$, where Zeus is known to have been worshipped with the epithet Limnenos. A peculiar feature of a significant number of monuments is that they were jointly dedicated to Zeus Bronton and a deceased individual. They, therefore, served as funerary monuments, placed under the god's protection ( $\left.\mathrm{n}^{\text {os }} 2-5,8-9,12-13,17,23,27-29,32\right) . \mathrm{n}^{\circ} 2$ is a good example for this practice: three brothers dedicated a stele both to their parents for memory's

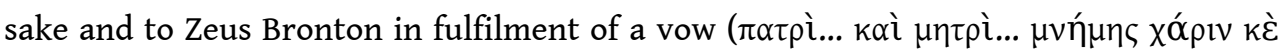

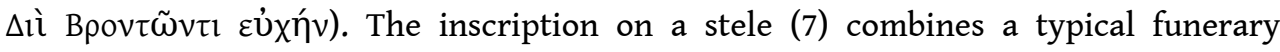




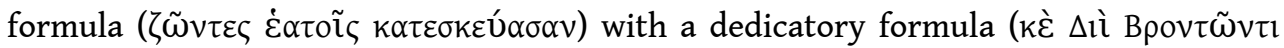

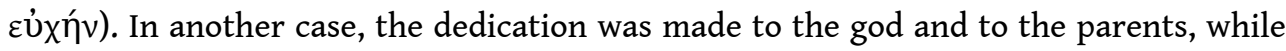

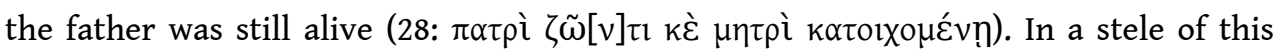
type, the names of the god and the deceased individual are in the dative (12: $\Delta i \mathrm{i}$

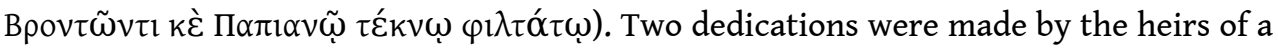

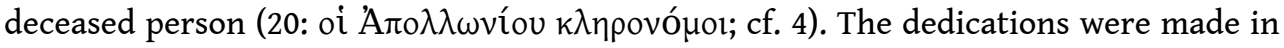

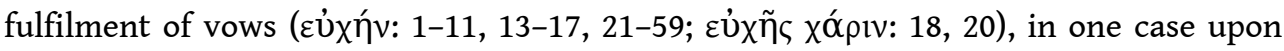

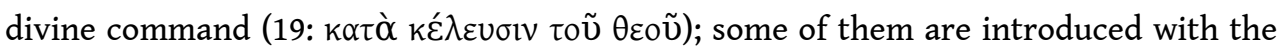

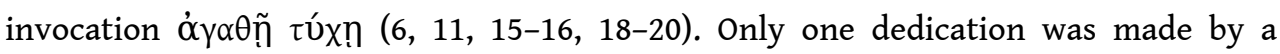
community, a village (19); usually, the dedicants were private individuals, alone or together with family members. The purpose of the vows is often mentioned: the protection of household, property, animals, and agricultural produce ( $\dot{v} \pi \dot{\varepsilon} \rho \tau \tilde{\omega} v i \delta i ́ \omega v$

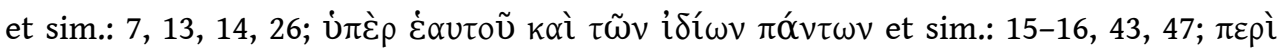

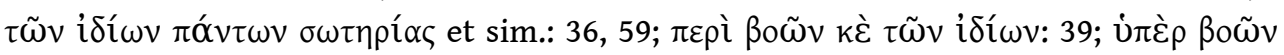

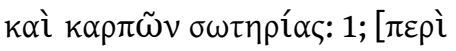

$\kappa \alpha \rho] \pi \tilde{\omega} v: 41$ ). Sometimes the god is expected to protect family members (35: $\dot{v} \pi \dot{\varepsilon} \rho$

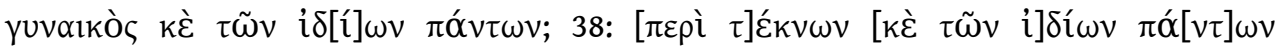

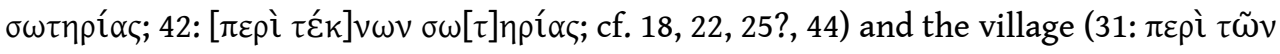

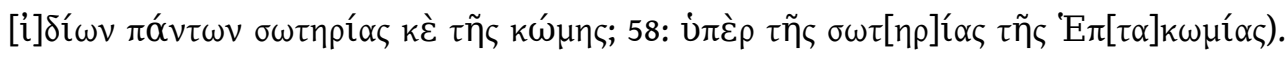
[In two cases the dedication was made for the well-being of large estates, i.e., the

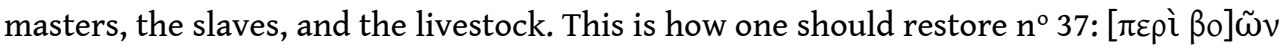

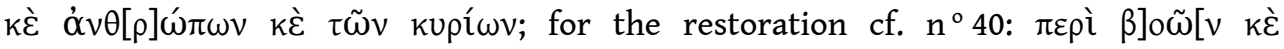

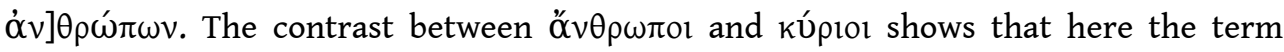
ó $v \theta \rho \omega \pi \circ \varsigma$ designates the slave (cf. e.g. SEG LVII 536 [11])]. We note an epitaph dedicated to Zeus Bronton, in which the deceased individuals are designated as

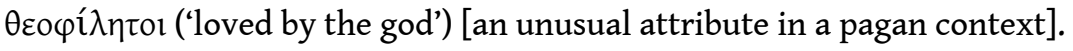

4) N.E. AKYÜREK şAHIN, “Zwei neue Inschriften für Hosios kai Dikaios”, Olba 18 (2010), p. 267-280 [BE 2011, 496; SEG LIX 1418, 1419; XL 1366]: Ed. pr. of two inscribed altars from Derecik (territory of Hadrianoi, 3rd cent. CE) [see also M.E. FUCHS, S. DELBARREBÄRTSCHI, AK 52 (2009), p. 164-179 and infra n 82]. The first text reads: 'Oбí

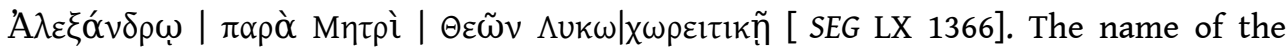

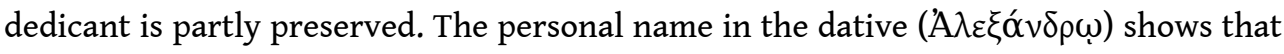
this is a funerary altar, dedicated both to Hosios Dikaios and to a deceased man. There are other examples of epitaphs jointly dedicated to gods, especially Zeus Bronton, and deceased persons [see supra $\mathrm{n}^{\circ} 3$ ]. The epithet of the Mother of the Gods derives from a place name, Lykos being a local river. [The ed. does not offer any explanation for the

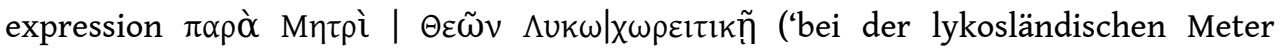

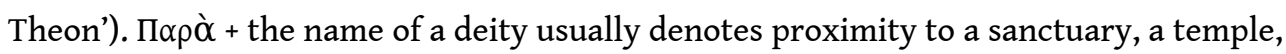
or a divine image (for the latter, cf. SGO II 09/06/19, which mentions a statue of

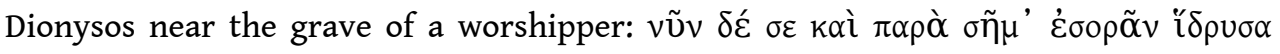

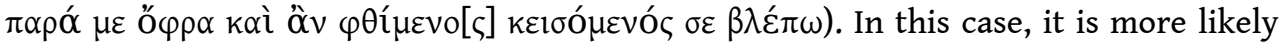
that the cemetery, where Alexandros was buried, was near the sanctuary of Meter. Hosios Dikaios (or Hosios [and] Dikaios) is often regarded as an intermediary between

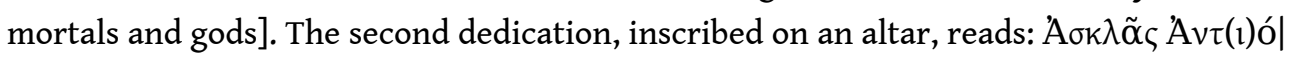

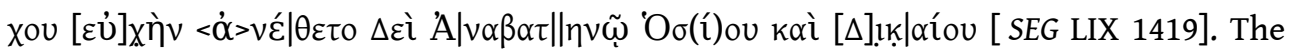
cult of Zeus Anabatenos was already attested in this area (I.Hadrianoi 9). The dedication was made in response to a command given by Hosios kai Dikaios in a dream; this is why 
the theonym is in the genitive [for a more convincing interpretation see infra $\mathrm{n}^{\circ}$ 82]. In an appendix, A.ş. publishes, without comments, a dedication to Zeus Kersoullos [SEG LIX 1418; for text and comments, see infra $\mathrm{n}^{\circ} 82$ ].

5) C. ANTONETTI, "I diversi aspetti di una koine socio-culturale nella Grecia nordoccidentale di epoca ellenistica", in Spazio ionico, p. 301-326 [SEG LX 2026]: In a study of a socio-cultural koine in northwestern Greece (Ionian Islands, Akarnania, Epeiros, south Illyria), Antonetti gives a panorama of cults, festivals, and cult associations, also discussing manumissions in the form of dedications to gods (p.305-307) and the

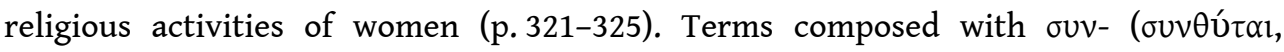
$\left.\sigma \cup v \varepsilon \lambda \varepsilon{ }^{\prime} \omega, \sigma \cup \mu \beta 1 \omega \tau \alpha i\right)$ are used as evidence for the importance of joint ritual activities (p. 315f.).

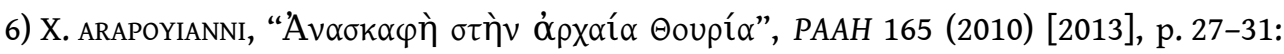
Ed. pr. of an octagonal receptacle for offerings ( $\theta$ $\sigma \alpha u \rho o ́ \varsigma)$ from a temple [of Asklepios; see infra $\mathrm{n}^{\circ}$ 8] in Thouria (late 4th/early 3rd cent., SEG LVIII 397; LX 447). The inscription names the 2 hierothytai and 3 damiourgoi, who were in office, when the thesauros was made, and the architect Theodoros.

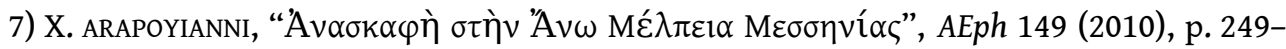
258 [SEG LXI 429]: Ed. pr. of a graffito in the interior of a phiale (ca. 500 BCE) found near a temple at Melpeia (near the border of Messenia and Arkadia). The vase was dedicated ( $\dot{\alpha} v \varepsilon \dot{\varepsilon} \theta \kappa \varepsilon[v ?])$ to a deity, of whom only the end of the name is preserved.

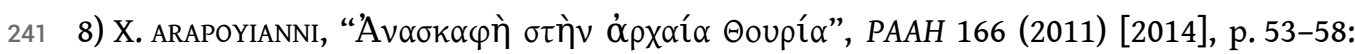
Ed. pr. of an inscribed statue base from Thouria (Hellenistic period; SEG LXI 309). A couple dedicated the statue of their son to Asklepios and Hygieia, after he had

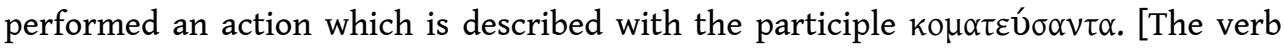

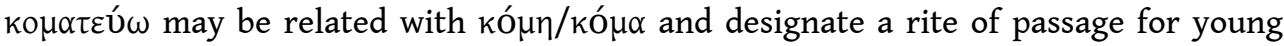
men involving a hair-offering; for hair-offerings cf. EBGR 2003, 57; 2008, 138; 2010, 14].

9) M. ARBABZADAH, "The Disappearing Man: $\Lambda \alpha \kappa i v \varepsilon l / \Lambda \alpha k i ́ v \varepsilon l<v>$ in a Greek Curse Tablet", ZPE 180 (2012), p. 253-255: A. discusses a curse tablet directed against charioteers of the faction of the Blues (EBGR 2002, 68). A problem of the earlier reading is that two charioteers or owners of horses (Hilarinus and Flaccinus) are mentioned twice, whereas

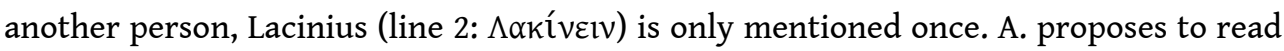
$\lambda \alpha \kappa i v \varepsilon l$, from the unattested verb $\lambda \alpha \kappa i v \varepsilon ́ \omega$ (cf. $\lambda \alpha \kappa \alpha$ ó $\omega$, 'to break'). In this reading, the names of the cursed individuals are mentioned twice, first as objects of $\lambda \alpha \kappa i v \varepsilon ́ \omega$, then as objects of $\kappa \alpha \tau \alpha \delta \varepsilon i ́ v \omega$.

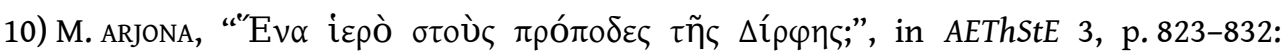
Archaeological remains at Kato Steni near Psachna, on the foot of Mt. Dirphe (Euboia),

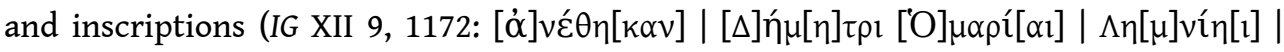

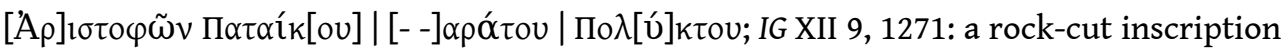
with the letters $\mathrm{A} \Pi \Lambda \Lambda[--][--] \mathrm{O}[--]$, interpreted by Papavasileiou as a reference to Apollo) have been interpreted as evidence for the existence of a sanctuary. A. summarizes earlier research on this site and critically examines the possibility that

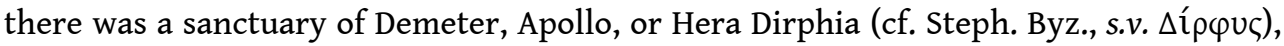
without reaching a firm conclusion.

11) N.T. ARRInGton, "The Form(s) and Date(s) of a Classical War Monument: Reevaluating IG I 1163 and the Case for Delion", ZPE 181 (2012), p. 61-75: A. studies the fragments associated with a monument for Athenian war dead ( $I G I^{2}$ 1163). The 
fragmentary epigram attributes the death of these Athenians to the intervention of a demi-god ('it was one of the demi-gods who stood against you in godly strife and did

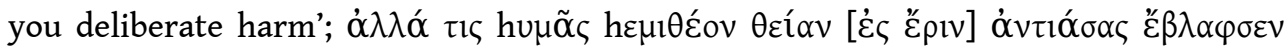
$\pi \rho o ́ \varphi p o v)$ and advises mortals to believe in oracles ('[- - ] together with your misfortune he brought to completion, and for all mortals for the future made the fulfillment of oracles credible to observe'; [h]

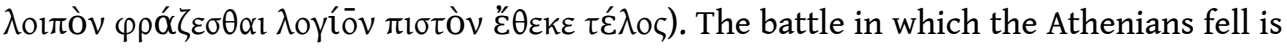
usually identified with that of Koroneia in 447/6, although identifications with the battle of Delion in 424/3 and the Sicilian expedition have been proposed. Raising doubts on whether the fragments of the stele (fr. a-c) belong together with the fragments of the base (fr. $d-f)$, A. recognizes four phases in the history of the monument. First five stelai were erected over the base; then a second base with a stele was added to the right of the monument; the monument was repaired after it was damaged in the late 3rd cent.; finally, the blocks of the base were re-used in the Valerian wall. The form of the monument and the addition of a stele can best be reconciled with a date in 424/3. The first base was erected for the dead of the battle of Delion - in that case the demi-god is Amphiaraos -, the second for the casualties at the battle in Lekythos, later in that year; Brasidas attributed his victory at Lekythos to divine intervention (Thuc. IV, 116, 2).

12) I. ARNAOUTOGLOU, "Group and Individuals in I.Rhamnous 59 (SEG 49.161)", in Individus, groupes et politique, p. 315-337: A. studies in detail the honorific decree of an association of Sarapiasts for a benefactor, who donated a piece of land. He tentatively attributes the foundation of this association to the close relations between Athens and Ptolemy III in 224 BCE.

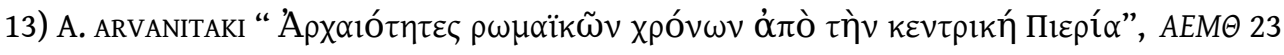
(2009) [2012], p. 173-182 [BE 2013, 263; SEG LX 637, 644]: Ed.pr of two dedications from the site Palekklisi, near Elatochori. For the dedication to Askepios and Hygieia see infra $\mathrm{n}^{\mathrm{o}}$ 137. The second dedication (p.178-180) is inscribed on a votive plaque with a representation of two pairs of ears in relief (2nd cent. CE). Sambatis made a dedication to Parthenos (i.e. the Syrian Goddess) for herself and for her daughter in fulfilment of a vow ( $\kappa<\alpha>\tau$ ' हن่Xńv).

14) S. BABAMova, Inscriptiones Stoborum (Studies in the Antiquities of Stobi I), Stobi, 2012: The epigraphic corpus of Stobi includes 308 Greek and Latin inscriptions. New texts are marked with an asterisk. All the inscriptions date to the 1st-3rd cent. Dedications [in the section 'Dedications', B. does not distinguish between dedications to gods and the setting up of images of gods]: Dedications are addressed to Artemis (3-5; 3, an altar; 4,

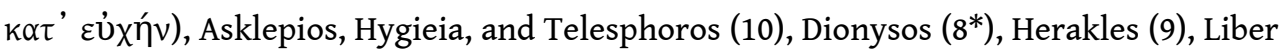

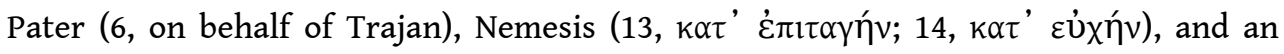

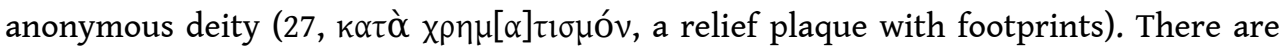
several references to statues of gods and reliefs with no indication as to the addressee of the dedication. A statue of Aphrodite was dedicated as $\delta \tilde{\omega} \rho \circ$ ov (1); the label Venus is written on the base of a statuette $\left(2^{*}\right)$. A group of public slaves dedicated statues of the Nymphs (11). A relief with a crude representation of Dionysos and his thiasos (?) bears

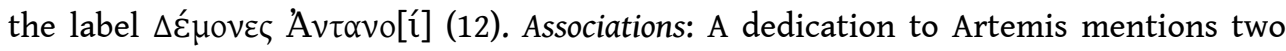

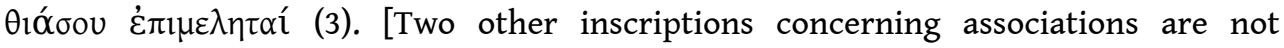
recognized as such. A text interpreted as a dedication to Dionysos (7: Bakxzĩov

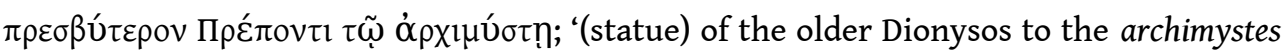

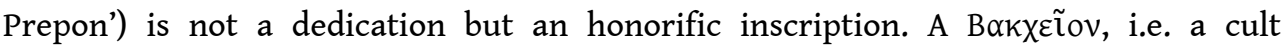


association of worshippers of Dionysos (cf. IG X 21,480 ) honors its president; the attribute $\pi \rho \varepsilon \sigma \beta \hat{\tau} \tau \varepsilon \rho \circ v$ implies that there were at least two Dionysiac associations. Also $\mathrm{n}^{\circ} 120^{*}$, included among the epitaphs, is certainly an inscription concerning an

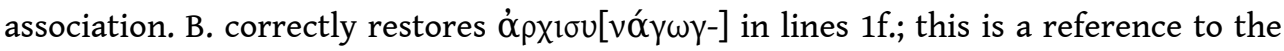
head of an association, possibly a woman, to judge from the ending of the name ([-

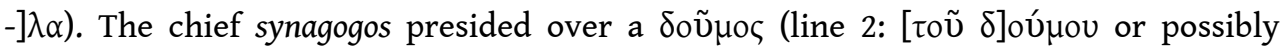

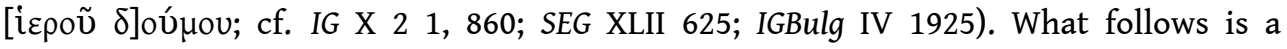

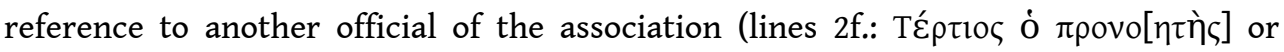

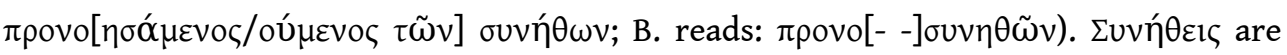

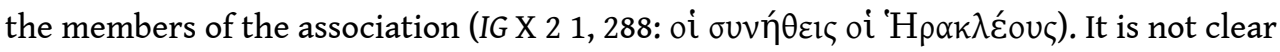
if this text is an epitaph, a dedication, or an honorific inscription]. Imperial cult: Individual augustales and groups of augustales made dedications to Deus Augustus (15, a statue of Ultrix Augusta; 16, a shrine of Isis; 17, a statue or shrine of Jupiter Liberator) and to Augustus and Iuppiter Optimus Maximus (18*). There is also a dedication to Hadrian (29). Honorific inscriptions and an invitatio ad munera attest the activities of high priests and high priestesses $\left(34,35^{*}, 38^{*}\right)$, some of whom belonged to the same prominent family of the Sentii $\left(34,35^{*}\right)$. A priestess of Isis also served as priestess of the Augusti (37). Cult personnel: A priestess of Isis Lochia and the emperors was honored for

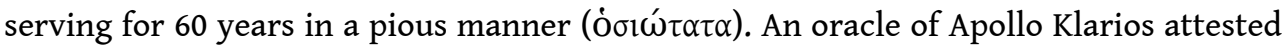

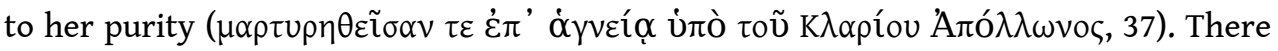

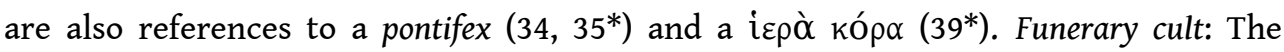
epitaph of Lykios (62) describes the actions to be taken after the burial of Lykios and his wife: the inner door of the heroon should be closed with a bar. The last clause of the

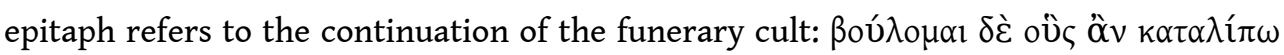

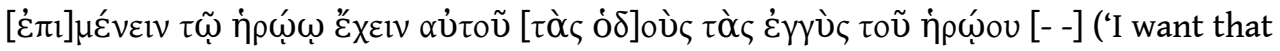
those to whom I leave this heroon to have fast ways to it'). [B.'s translation is wrong,

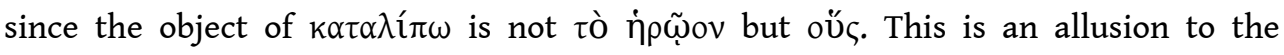
testamentary manumission of slaves, under the condition that they take care of the

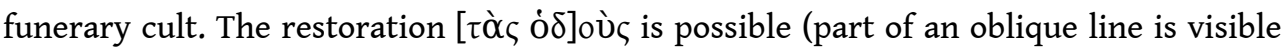

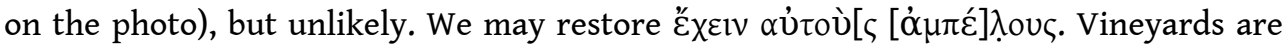
often associated with burial grounds (e.g. P. HERRMANN, K.Z. POLATKAN, Das Testament des

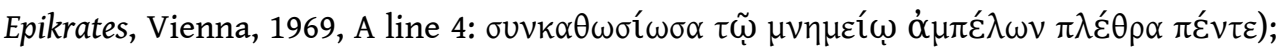
for the donation of vineyards to individuals with the obligation to take care of the

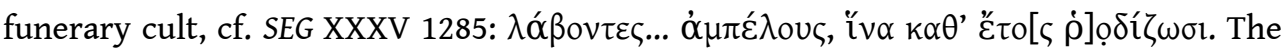
meaning is: 'I wish that those, whom I leave in charge of taking care of the heroon, own the [vineyards] that are close to it [- -]'. I also note that the edition of $n^{\circ} 66^{*}$ requires

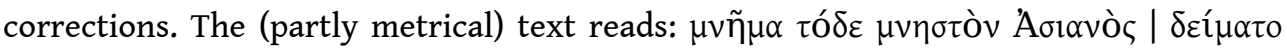

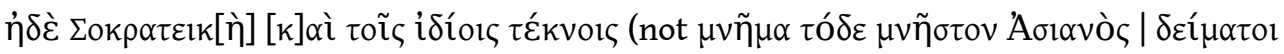

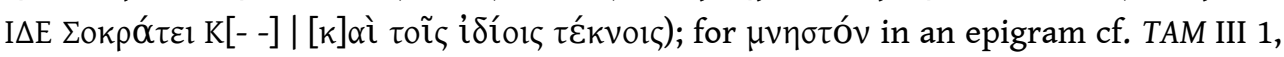
590 lines 4f.: $\sigma \tilde{\eta} \mu \alpha . . . \mu \nu \eta \sigma \tau o ́ v]$. Jews: There is a large number of Jewish inscriptions (1926).

15) D. BALDASSARA, "Le liste cultuali della Grecia nord-occidentale", in Spazio ionico, p. 341-371 [BE 2011, 365; SEG LX 545, 567, 567 bis, 572, 608-610]: B. collects, (re)publishes, and discusses dedications from Akarnania, Korkyra, and Epeiros that list the magistrates and other functionaries who participated in religious ceremonies [see also infra $\left.\mathrm{n}^{\circ} 180\right]$. Her list includes two inedita from Ambrakia: two dedications to Hestia, Zeus, and Aphrodite (T1-T2, early 2nd cent.). These lists mention various 


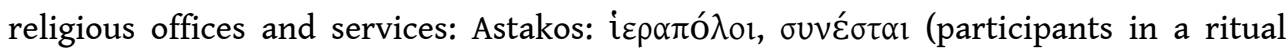

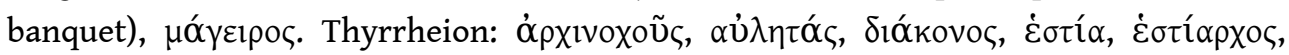

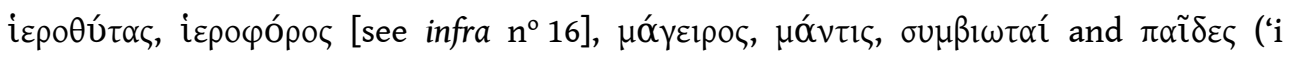

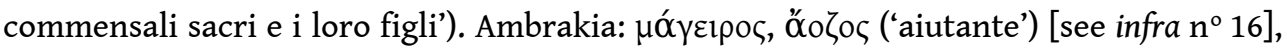

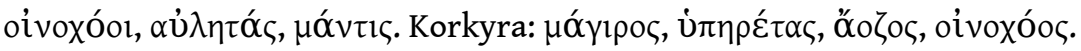

16) D. BALDASSARA, D. RUGGIERI, "Intorno al sacrificio: aozos e hierophoros", in Spazio ionico, p. 373-384 [SEG LX 545]: The authors discuss the meaning of the terms óo oc and

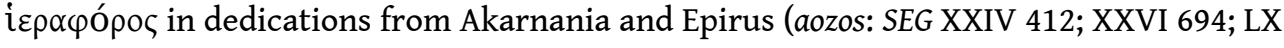
608-609; CABANES, L'Épire $\mathrm{n}^{\circ}$ 19; Lhôte, Lamelles oraculaires $\mathrm{n}^{\circ}$ 123; hierophoros: IG IX ${ }^{2} 1$,

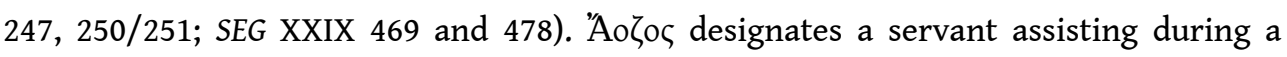
sacrifice (cf. Aeschylus, Agamemnon 228-231; Kallimachos, fr. 563 ed. Pfeiffer; Athenaios

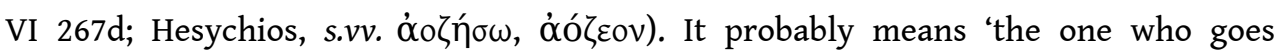
together'. 'Iврофópoৎ designates an individual who carries sacred objects or the image of a deity, often in connection with the cult of Egyptian gods (cf. IG II ${ }^{2} 4771$; VII 2681, 3426; X 2 1, 16, 58; XII 5, 291; XII 6, 600; SEG LV 1659; I.Reggio Calabria 7).

17) M. BăRBULESCU, L. BozoIANU, "Inscriptions inédites et révisées de la collection du Musée d'Histoire Nationale et d'Archéologie de Constanza. II", Pontica 43 (2010), p. 347376 [BE 2011, 450; SEG LX 790]: Ed. pr. of a dedication found at Valea Seacă (area of Tomis), probably addressed to the Nymphs (p. 361-367, 2nd cent. CE).

18) V.N. BARDANI, S.V. TRACY, Inscriptiones Graecae. Voluminis II et III editio tertia. Inscriptiones Atticae Euclidis anno posteriores. Pars I. Leges et decreta. Fasciculus V. Leges et decreta annorum 229/8-168/7, Berlin, 2012: This volume (IG $\mathrm{II}^{3}$ ) assembles the Athenian laws and decrees of the period from the liberation of Athens from the Antigonid garrison to the end of the Third Macedonian War (229-167 BCE). Most of these texts have been repeatedly published. New texts are marked with an asterisk. Cult regulations et sim.: A fragmentary decree $(1220$, ca. $210 \mathrm{BCE})$ concerns the offering of a sacrifice to

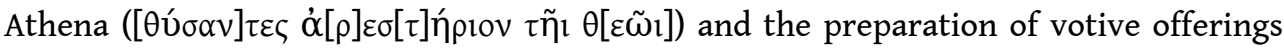
under the supervision of a committee, the general, the priest, and the architect. Festivals: Festivals are usually mentioned in the context of the announcement of honors: Dionysia $(1147,1150,1176,1178,1185,1215,1218,1256,1258,1278,1281,1283,1290$, 1292, 1348, 1362, 1390, 1392, 1448), Eleusinia (1150, 1176, 1178, 1185, 1218, 1256, 1258, $1278,1281,1290,1292,1348,1362,1448)$, Panathenaia $(1147,1150,1176,1178,1185$, $1218,1256,1258,1278,1281,1290,1292,1348,1362,1448)$, and Ptolemaia $(1150,1178$, $1258,1278,1281,1290,1292,1362)$. The Prienians were honored for the participation in the Panathenaia (1239), the Milesians for the attendance of the Megala Mysteria (1372). A decree honors the father of a kanephoros and the epimeletai of the procession of the Dionysia for their conduct during the procession (1284). A fragmentary honorific decree for a cavalry officer refers to the service he rendered during the celebration of the Nemesia, probably by providing security (1281). Three decrees concern the acceptance by the Athenians of the agonistic festivals Leukophryena (1170), Lykaia (1184), and an undetermined contest (1183). A decree of Gonnoi concerns the appointment of a theorodokos (1145); an Athenian decree, inscribed on the same stele, provides for honors for the theorodokoi of the Eleusinia, the Panathenaia, and the Mysteries; their names should be reported by the spondophoroi (for spondophoroi, cf. 1331). An Athenian theorodokos for an Ephesian festival is mentioned in a fragmentary decree (1150). Foreign theoroi are honored with two decrees $(1215,1261)$. Rituals: A small fragment (1417, early 2nd cent.) mentions the festival Eleutheria of Plataia and 
the competition between Athens and Sparta for the privilege to lead the procession ( prytaneis for the performance of sacrifices on behalf of the Athenian people, mostly sacrifices offered to Apollo Prostaterios and Artemis Boulaia (1139, 1144, 1149, 1153, $1155,1162 *$, 1165, 1168, 1177, 1197, 1198, 1231, 1233, 1246, 1248, 1259, 1263, 1268, 1274, $1275,1289,1293,1295,1296,1299,1301,1304,1305,1307,1310,1311,1316,1318,1320$, 1321, 1324, 1328, 1333, 1344, 1377, 1396, 1397, 1400, 1415, 1416); several decrees also mention Artemis Phosphoros (1295-1296, 1316, 1318, 1324, 1328, 1333, 1415, 1416), Athena Archegetis (1296), and Zeus Ktesios (1304). Honorific inscriptions also honor the ephebes for their conduct and the performance of religious activities, inter alia, the attendance of the mysteries, the Epitaphia, the Proerosia, and the Dionysia, the offering of a sacrifice to Aias in Salamis, Asklepios, Hermes, the Semnai Theai (1332), and the gods and benefactors (1313), the participation in a procession for the Demokratia, and the payment of a visit to the polyandreion in Marathon $(1166,1176,1256,1264,1285$, 1290, 1313, 1332; see esp. 1313). Other officials honored for offering sacrifices and performing religious duties include an archon (1298), magistrates who offered sacrifices at the Chalkeia (1388), the epimeletai of the Mysteries (1164, 1182, 1188, 1329),

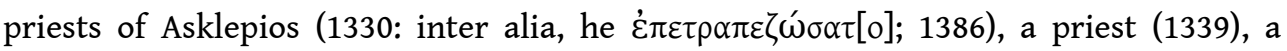
priestess (of Demeter?; she receives a myrtle crown: 1189; cf. 1209), a priestess of Aglauros who offered sacrifices to Aglauros, Ares, Helios, the Horai, Apollo, and other

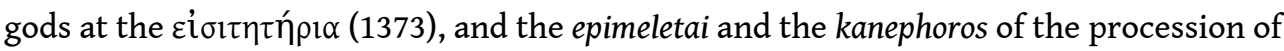
the Dionysia (1284). [A small but interesting detail: the decree that honors Eumenes II and his brothers for placing Antiochos IV on the Seleucid throne (1323, 175 BCE), alludes to ritual actions of enthronization (lines 17-22): "having adorned him with the

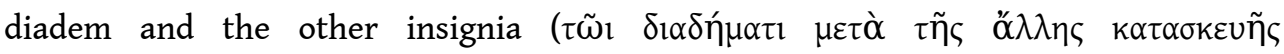

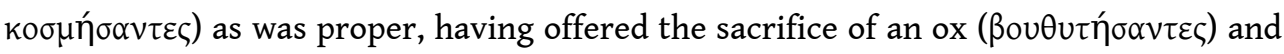
having exchanged promises of trust with all goodwill and affection, they jointly established King Antiochos to the ancestral rule in an illustrious manner ( $\dot{\alpha} \xi$ io $\left.\left.{ }^{\circ} \gamma \omega \varsigma\right) "\right]$. Sanctuaries and sacred buildings: Many texts refer to the publication of decrees in sacred places, inter alia, near the altar of Artemis Boulaia (1150), near the temple of Demeter (1189), in the Eleusinion $(1209,1215)$, near the Hermai $(1281)$, in the Lykeion $(1290,1362)$, and in the sanctuary of Dionysos (1284). Sanctuaries outside of Athens that are mentioned in Athenian decrees include the sanctuaries of Athena Nikephoros in Pergamon (1323), Apollo in Daphne (1323), and Dionysos in Lamia (1171). Several honorific decrees also include provisions for the erection of statues in sanctuaries, e.g. in that of the Demos and the Charites $(1137,1374,1375)$. A decree concerns the construction of a structure, and the purchase of a libanotis and a phiale (1151) for an undetermined cult. A decree concerns the melting down of old silver and gold dedications in the sanctuary of Heros Iatros and the use of the metal for the making of a dedication (1154); the names of the original dedicants were inscribed on the stele. A small fragment seems to be concerned with dedications (1418). Divination:

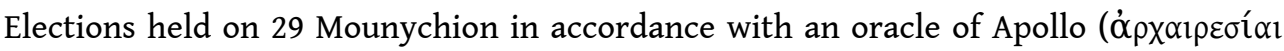

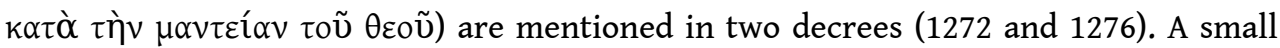

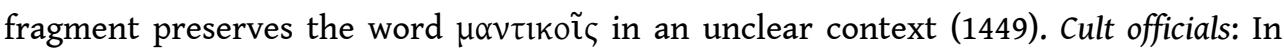
addition to priests and cult officials mentioned above, there are references to a hieromnemon (1288), priests of Ptolemy (1337) and Attalos (1337), and priests of tribal eponymous heroes $(1367,1396)$. 
252 19) J. BARTELS, “Augustus in Amathus (Zypern)”, ZPE 181 (2012), p. 91-94: B. presents an improved edition of a dedication to an emperor from Amathous (infra $\mathrm{n}^{\circ} 66$ ), recognizing the emperor as Augustus. Another dedication to Augustus from this city was already known: IGR III, 973. Inscriptions for the first princeps are rare in Cyprus.

20) N. BELAYCHE, “Deus deum... summorum maximus (Apuleius): Ritual Expressions of Distinction in the Divine World of the Imperial Period", in One God, p. 141-166 [SEG LX 2005]: Drawing on the literary and epigraphic evidence (gems, amulets, dedications), B. examines the religious and ritual functions of acclamations in which 'one god' is

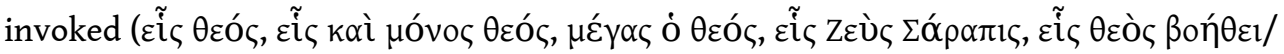
$\beta$ ¡† $\theta$ ó $)$. Such exaltations use 'possibly monotheist language but always in an ambiance of a plural divine world'; they were used in order to underline the superiority of a divinity. The context in which they should be seen is that of the competitive spirit that governed social relations in the Roman Empire. "The term heis theos, "alone/unique", signifies that the divinity was alone of his type, unmatched (praestans in Apuleius' words), capable of achieving the impossible, but not one god as such' (p. 166) [cf. infra $\left.\mathrm{n}^{\circ} 39\right]$.

21) S.S. BESSONOVA, "Finds of Greek Pottery with Graffiti in Skythian Tombs of the North Shore of the Black Sea", Bosporskie issledovanija 10 (2005), p. 5-21 [Non vidimus; see A. AVRAM, BE 2009, 391]: The author assembles graffiti on vases found in Skythian tombs.

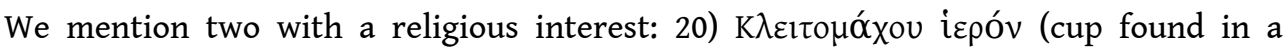
kurgan in Brannoe Pole, Crimea, 5th/4th cent.) [see SEG LVIII 744: dedication to an unknown hero or dedication by Kleitomachos]. 21) "Ekó $\tau \eta \varsigma$ (kantharos found in a kurgan at Aktašski mogilnik, undated) [used for libations to Hekate; cf. EBGR 2007, 6 and 2010, 115].

22) E. BOGIN, "Asylia sotto gli occhi di Artemide: Considerazioni a partire da un decreto di Calidone", in Spazio ionico, p. 395-407 [SEG LX 537]: A decree of the Aitolian koinon grants asylia to Lousoi (IG IX ${ }^{2}$ 1, 135; RIGSBY, Asylia, p. 91/92, Kalydon, ca. 225-200). B. argues that the asylia was not granted to the sanctuary of Artemis but to the citizens of Lousoi and associates this document with the Aitolian attack against Kleitor and Kynaitha in 220 BCE (Polybios IV, 18, 7-12 and IV, 19, 2-4).

23) M. BONANNO ARAVANTINOS, "Trofei di età romana della Beozia: una nase da Livadeia", in T. NOGALES, I. RODÀ (eds.), Roma y las provincias: modelo y difusión I, Rome, 2011, p. 419427: B.A. identifies a base from Lebadeia, decorated with Nikai crowning a trophy beneath which kneel two bound Eastern barbarians, as a monument commemorating Sulla's victory at Chaironeia in $86 \mathrm{BCE}$. According to Plutarch (Sulla 17) the oracle of Trophonios predicted Sulla's victories. Other monuments connected with this victory are a dedication from Chaironeia (SEG XLI 448) and a trophy erected by Sulla and found in 2004 east of Orchomenos. The unpublished inscription of this trophy reports that Sulla dedicated it to Ares, Nike, and Aphrodite (p. 423). B.A. attributes the base from Lebadeia to a local workshop. She argues that a votive relief from Koroneia, dedicated to Sabazios (SEG XL 410), is also the product of a local workshop and should be dated to the 1st cent. BCE (p. 425). [On the trophy of Sulla see now P. ASSENMAKER, "Les trophées sylaniens de Chéronée: une relecture de Plutarque, Vie de Sylla 19, 9-10 à la lumière des découvertes archéologiques", Latomus 72 (2013), p. 946-955].

23 bis) F. BOSCH-PUCHE, "L"autel' du temple d'Alexandre le Grand à Bahariya", BIFAO 108 (2008), p. 29-44 [SEG LIX 1764]: Ed. pr. of a very interesting bilingual hieroglyphic/ 
Greek inscription on an altar found in the Bahariya Oasis in Egypt. The text is a dedication of Alexander the Great to Ammon, his father (B $\alpha \sigma \imath \lambda \varepsilon \dot{\nu} \varsigma$ A $A \lambda^{\varepsilon} \xi<\alpha>v \delta \rho \circ \varsigma$ 'A $\left.\mu \mu \omega v \imath \tau[\tilde{\omega}]_{\imath} \pi \alpha \tau \rho i ́\right)$. The hieroglyphic inscription gives Alexander's complete Pharaohnic titulature. Altars dedicated by Alexander to 'Ammon, his father' are mentioned by Philostratos (Vita Apollonii II, 43).

24) D. BOSNAKIS, K. HALlOF, Inscriptiones Graecae. Volumen XII. Fasciculus IV. Pars II. Inscriptiones Coi Insulae. Catalogi, dedicationes, tituli honorarii, termini, Berlin, 2012 [BE 2013, 334]: The second fascicule of the Koan corpus contains catalogues of sponsors, victors, magistrates, citizens, and foreigners, dedications, honorific inscriptions, and boundary markers. Numerous texts are directly relevant to the religious life in Kos. New texts are marked with an asterisk. Sanctuaries and sacred buildings: Some of the lists of sponsors of public projects concern cult buildings and cult activities: a sanctuary of Demeter (430, ca. 200; all the contributors are women; cf. 431); a sanctuary of Aphrodite (434, ca. 200180 ); the funding of sacrifices to Asklepios and the celebration of a panegyris ( $\left.435^{*}\right)$; the construction of a silver image of Augustus (449). A man dedicated to the Moirai the statues ( ó$\left._{\alpha} \vee \alpha\right)$ of the gods, the sanctuary, and the adjacent buildings, that had been damaged during a war, during the priesthood of his daughter $(607,1$ st cent.). The services of an anonymous benefactor (1037) include the restoration of buildings, possibly after the earthquake of $47 \mathrm{CE}$; the earthquake had damaged the quadriga of Victory and Emperor Claudius and other statues near the sanctuary of Asklepios. Important information for the sacred property of sanctuaries is provided by boundary stones that mark the boundaries of property belonging to various gods or sanctuaries

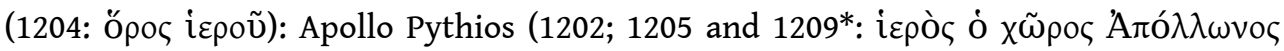

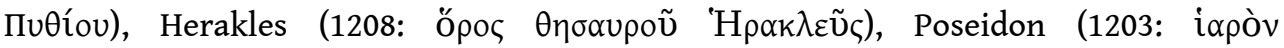

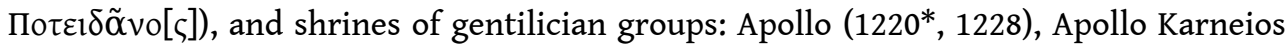
of the Pasthemiadai and the Nostidai (1223), Artemis of the [--]andridai (1222*), Athena Phatria of the Otobalidai (1212) and anonymous groups $\left(1218^{*}, 1226\right)$, the Moirai of the Astyklidai (1216) and the Laistrapidai (1232), Poseidon Geraistios of the Orphikidai (1224), the Maionidai (1227), and the Kentreidai (1231*), Zeus Hikesios of the Simonidai (1215), the Laistrapidai (1219), the Nestoridai (1225), the [--]adia, and anonymous groups $(1217,1230)$, Zeus Machaneus of an anonymous group (1233), Zeus Patroios of the Kalinai (1210), the Pothelidai (1234), and the Etymobysiadai (1236), Zeus of the [--]eidai (1211) and the Plaxidai (1214), Zeus Phatrios of the Nestoridai (1221*), Zeus Phatrios and Athena of the Euryanaktidai (1213). Kos possessed public and sacred land in Cyprus (866), probably given to the Koans by the Ptolemies; a Roman proconsul was honored for restoring it to Kos. Several boundary markers designate the property of Athena in Athens (A $\theta \varepsilon v \tilde{\alpha}$ A $A \theta \varepsilon v \tilde{\omega} v \mu \varepsilon \delta \varepsilon \varepsilon^{\circ} \sigma \alpha$ ) during the period of the Athenian hegemony $(1237,1238,1239$ ?). An interesting group of boundary markers define parts of the fortifications ( $\mu$ oi $\rho \alpha_{1}$ ) named after deities: Zeus Olympios (1189), Apollo Karneios (1190), Hermas Kyllanios (1191), Hera Argeia (1192*), and Artemis Toxitis (1193).

Rituals: An inscription of the deme of the Hippiotai $(1146,1$ st cent. CE) proudly reports that the deme was again granted by the city the right to organize the festival of the

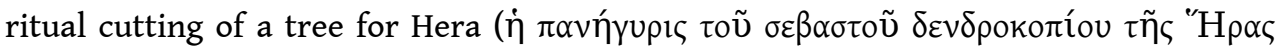

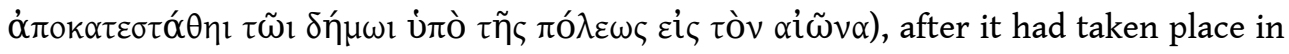

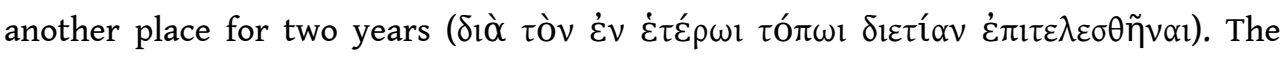

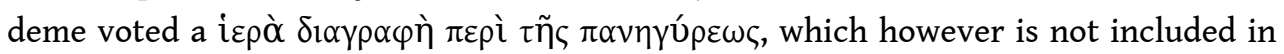
the inscription. In later times, the stone was used for the publication of an honorific 
inscription for a high priest, priest, and panegyriarches four times. Agonistic festivals: Numerous agonistic inscriptions list the names of victorious contestants at the Dionysia (451-452) and the Asklepieia (453-454) in Kos (late 3rd and early 2nd cent.) and provide information on athletes and artists who won victories at the following festivals: Aktia (938, 947, 1166*), Agrippeia (938) and Agrippeia Nea in Kos (938), Apollonia in Myndos (938), Archegesia in Halikarnassos (935), Asklepieia in Kos (938, 946*), Aspis in Argos (1166*), Kapitolia (950), Dionysia in Teos (938), Doreia in Knidos (938), Eleusinia (035), Hekatesia in Stratonikeia (935), Herakleia in Iasos (938), Isthmia (935, 939, 948*, 1166*), Klaudeia in Rhodes $\left(1166^{*}\right)$, Koinos Asias $\left(1166^{*}\right)$, Koinos Ionon $\left(1166^{*}\right)$, Koinos Makedonon $\left(1166^{*}\right)$, Koinos Thessalon $\left(1166^{*}\right)$, Lykaia $\left(1166^{*}\right)$, Nemea $\left(938,943,1166^{*}\right)$, Megala Kaisareia in Kos $(935,938)$, Kaisareia in honor of Caius Caesar in Kos (938), Eleutheria Kaisareia (935), Kaisareia in Halikarnassos (938), Metropolis (935), Patrai (938), and Sardeis (938), Klaria (935), Olympia (942), Panathenaia Megala (938), Rhomaia in Kos (935), Rhomaia Sebasta in Pergamon (938), Sebasta of Neapolis (?, 944*), and Theogamia in Nysa (935). We note several inscriptions referring to victories in

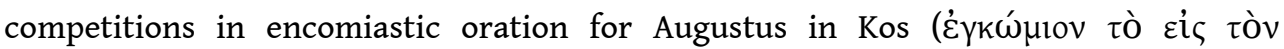

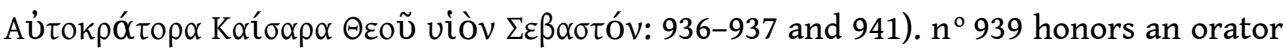
who won the prizes in encomiastic orations for emperors and local gods in many festivals in Asia and Kos. The statue of the poetess Delphis was rededicated to honor a

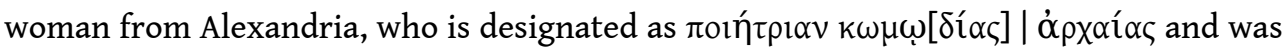
victorious at the Sebasta Olympia, the Koinos Asias in Pergamon and other sacred

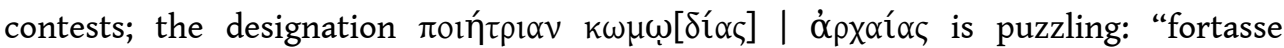
comoedias veteras adaptavit" (845). A victorious athlete was $\dot{\alpha} \rho x ı \varepsilon \rho \varepsilon \nu ̀ \varsigma \tau \tilde{\omega} v \Sigma \varepsilon \beta \alpha \sigma \tau \tilde{\omega} v$

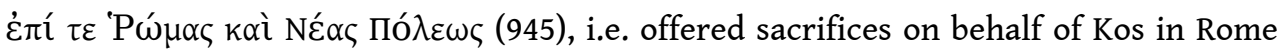
and Neapolis.

Dedications: A large group of dedications is connected with the gymnasion and its cults: the cults of Zeus Alseios and Athena Alseia $(588,590,595-597,599,600)$, Herakles and Hermes (589, 594; cf. 591), the Muses (592-593), and Apollo (593). The dedications in the gymnasion were made by paidonomoi $(588-589,595-596,598$; cf. 597: a dedication in honor of paidonomoi), gymnasiarchoi (591), the priest of the Muses (599), and the winners of athletic and musical contests $(590,592-594)$. The most interesting text in this group is an epigram commemorating the dedication of a statue of Herakles, 'the most trustworthy guardian of the children' to Zeus Alseios and Athena Alseia $(588,2 \mathrm{nd}$ cent.); the dedication was made for the health and good behavior of the boys; Herakles is designated as ancestor of the dedicant, a paidonomos ( $\dot{\alpha} \rho \chi \alpha \gamma o ̀ v ~ \gamma \varepsilon v \varepsilon \tilde{\alpha} \varsigma$, , $\varepsilon$ vov

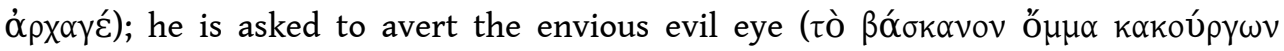
кoí $\mu 1 \sigma 0 v)$ from the boys and to protect the paidonomos, whose affection towards the boys is compared to that of a father. A second large group consists of dedications made by boards of magistrates. Dedications by the monarchos and the hieropoioi are addressed to Aphrodite and Homonoia (601), Asklepios and Hygieia (602), and the gods (606: dedication of a statue of Eueteria). The priest of Apollo and the hieropoioi in Halasarna made dedications to Hekate Stratia $\left(624-628,631 ; \mathrm{cf} .629,630^{*}, 631\right)$ and Hekate Stratia and Herakles $\left(632^{*}\right)$, as well as a dedication after offering a sacrifice (612,

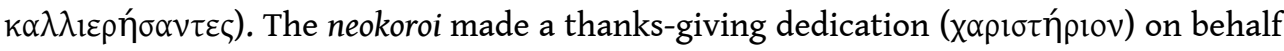
of the city to gods, whose name is not preserved, and to the Divi Augusti, who were

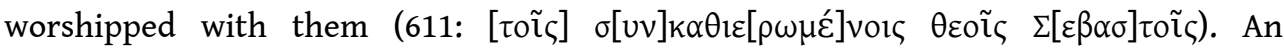

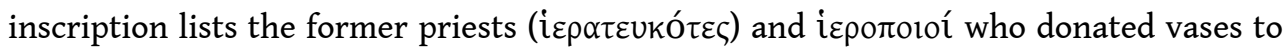


Apollo (Halasarna, 458, ca. 200). Other dedications made by cult personnel include

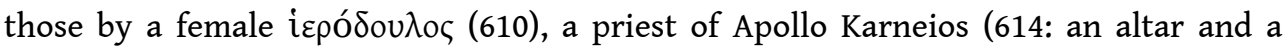
gate), and hierophylakes $\left(615^{*}, 617^{*}, 618^{*}-620^{*}\right)$. A third group consists of dedications

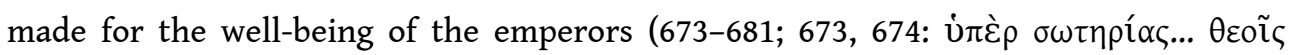

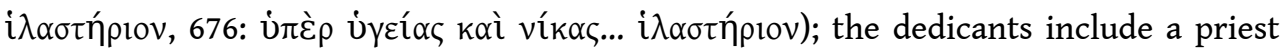
(675) and a high priestess of the Sebastoi and Apollo (678*). In one case the dedicated object was a statue of Dionysos (677). A group of four inscriptions records dedications made by individuals (541), the gerousia and the citizens (543), and a professional association (544) to several gods in expression of gratitude for saving Kos, possibly from

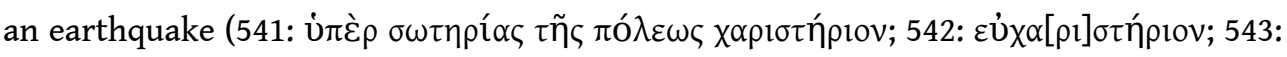

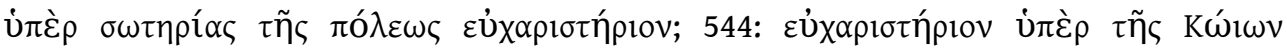
$\pi 0$ $\lambda \varepsilon \omega \varsigma)$. The dedications are addressed to Zeus Olympios, Serapis, Hera Ourania, and the other gods (541), Zeus Olympios, Hera Olympia, and the other gods who save the city (542), Zeus Hypsistos, Hera Ourania, Asklepios, Hygieia, and the other gods (543), and Zeus Hypsistos, Hera Ourania, Poseidon Asphaleios, Apollo, and all the other gods (544). A Koan specialty are the numerous altars that were dedicated to the Theoi Patroioi for the well-being of important Koan statesmen: Nikias, who ruled Kos as tyrant under Marc Antony $\left(682-711 ; 685^{*}, 686^{*}, 688^{*}, 691^{*}, 694^{*}, 704^{*}, 706^{*}, 707^{*}, 710^{*}\right.$, 711*); Emperor Claudius' doctor C. Stertinius Xenophon (712-779; 715*, 735*, 748*-751*, $\left.759^{*}, 760^{*}, 766^{*}, 769^{*}, 777^{*}-779^{*}\right)$; M. Aelius Sabinianus, an important political personality of the 2nd cent. CE $\left(783-809 ; 796^{*}, 800^{*}, 803^{*}, 809^{*}\right)$; the otherwise unknown M'. Spedius Rufinus Phaedrus (810-813). Altars were dedicated to Apollo for

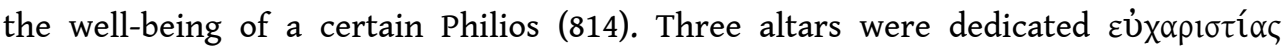

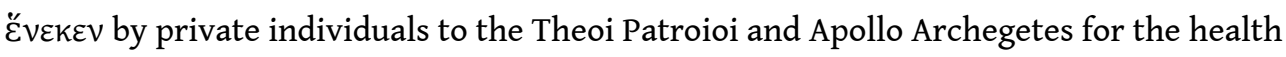
and well-being of M. Ulpus Traianus, the father of the future Emperor Trajan, governor of Asia in 79 CE (780-782). Finally, an altar was dedicated by Halasarna to Apollo as

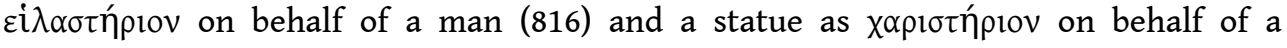
victorious kitharode (1166*).

There are dedications to the following deities: Aphrodite: 563 (by soldiers, A $\varphi \rho \circ \delta i ́ \tau \alpha 1$

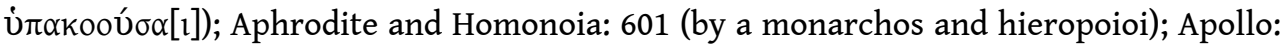

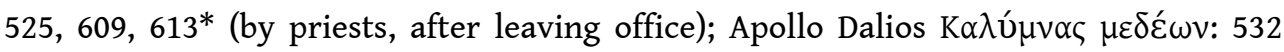

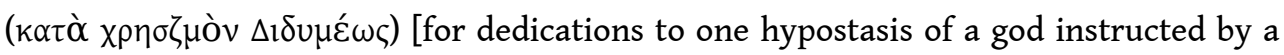
different hypostasis of the same god, see infra $\mathrm{n}^{\circ}$ 82]; Apollo Didymeus: 566-567 (by Milesian soldiers; in $\mathrm{n}^{\circ} 566$, Apollo is called Soter); Apollo Kalymnios and other $\theta \varepsilon o \mathrm{i}$

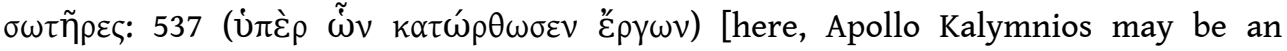
emperor; cf. the dedication of a statue of Sebastos Apollon Kalymnios, i.e. an emperor identified as Apollo (894*). Could this emperor be Caligula, whose statue was dedicated

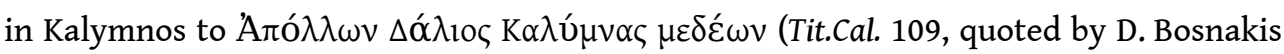
ad loc.)?]; Apollo Pythios: 529*; Apollo and Dionysos: 521 [n 503 from Halasarna, which is placed among the dedications to Asklepios, more likely is a dedication to Apollo; when the stone was first used for a dedication, the name of the addressee was not mentioned; but the dedicated object was a statue of Artemis or of a female member of

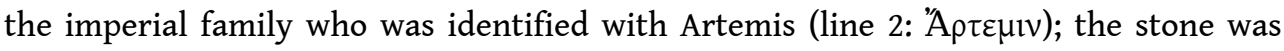
later re-used for a dedication to Apollo (line 5: A $\pi$ ó $\lambda \lambda \omega v \mathrm{l})$ ]; Artemis: 520; Artemis

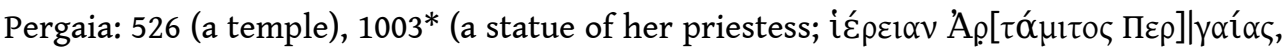

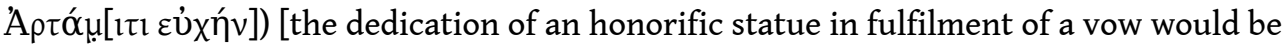

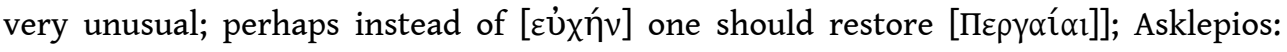




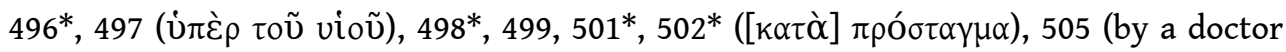
and his wife), 506, 507* (see below), 605 (a temple dedicated by a priest of Asklepios);

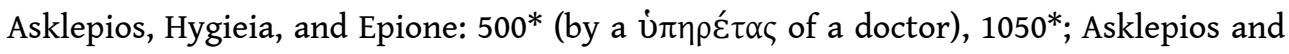
Hygieia: 504*; Athena: 517; Minerva: 531 (in Latin); Basileus of Kaunos: 547 (dedication

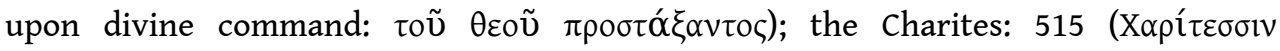

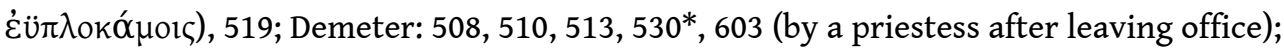
Demeter Karpophoros: 518*; Kore: 509, 511, 512 (by a priestess, ió $\rho \eta$ ); Demeter Soteira and Kore Soteira: 514 (see below); Eirene: 580 (by agoranomoi); Hekate Soteira: 564 (by an officer); Hera Ourania: 546; Herakles: $523^{*}, 539^{*}$ (by a former magistrate); Hermes: 522, 527, 528*; Hestia Phamia and the emperors: 540*; Hestia Phamia and the demos:

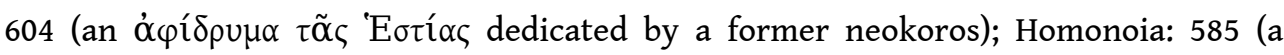
temple and a statue dedicated by a magistrate), 586 (by a former magistrate); Leto (653*); Poseidon Asphaleios: 622 (by a priest for life); Poseidon Hippios: 565 (by soldiers); Theos Hypsistos: 556, 559; Tyche Agathe and Agathos Daimon: 533; Zeus: 665*. Dedications to the gods were made by magistrates after their term in office: 568-569,

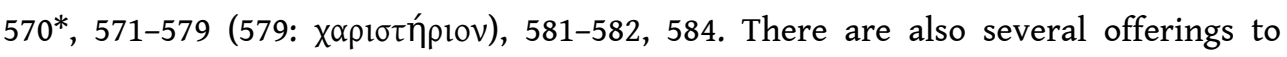

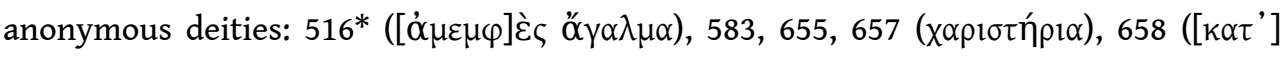

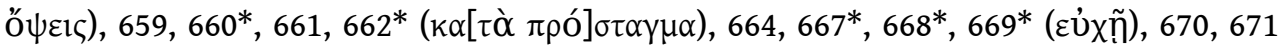

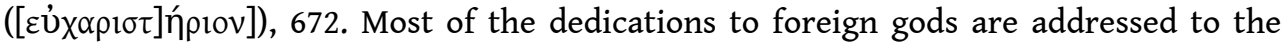

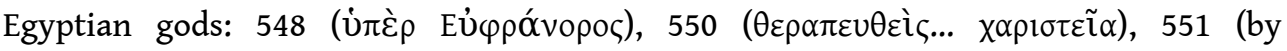

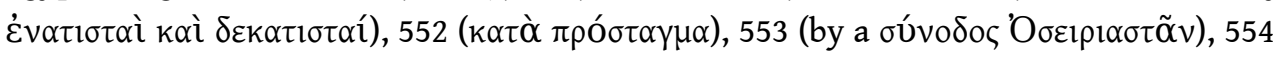

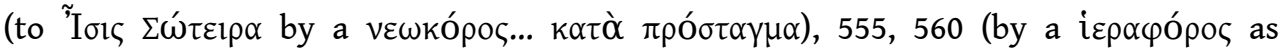

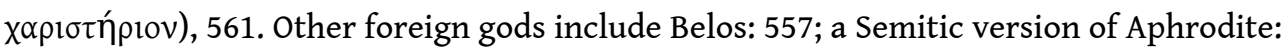

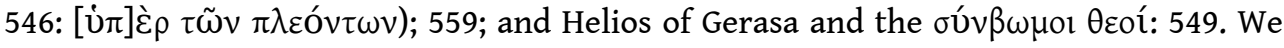
also note the dedication of honorific statues to the gods $\left(974^{*}, 976^{*}, 977,980,984,986\right.$, 987, 991, 992* 996*, 998, 1029, 1056*) and dedications of statues of gods: Aphrodite (535), Asklepios (587), Eueteria (606), Nike (524*), Pan (536). We comment on a small selection of interesting dedications. An epigram commemorates the dedication of the statue of a boy by his father as expression of gratitude for the son's cure: [ $\dot{\alpha}] v \theta^{\prime}$ ujyín

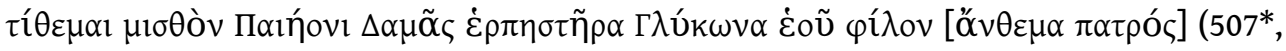
2nd cent. CE). A dedicatory epigram commemorates a miracle attributed to Demeter and Kore (514): The prayers of the dedicant, Aischron, and other female worshippers during the performance of mysteries of Demeter and Kore (probably during the Thesmophoria) stopped an earthquake [on this text see EBGR 2011, 58]. A priest

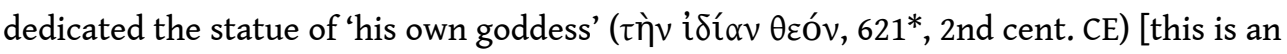
interesting expression of devotion; for parallels see A. CHANIOTIS, "Emotional Community through Ritual. Initiates, Citizens, and Pilgrims as Emotional Communities in the Greek World", in A. CHANIotis (ed.), Ritual Dynamics in the Ancient Mediterranean: Agency, Emotion, Gender, Representation, Stuttgart, 2011, p. 274 note 39]. An honorific inscription for a woman who was granted heroic honors $\left(853^{*}, 2\right.$ nd cent. CE) lists all the objects that she had dedicated, inter alia a silver lamp, cult objects for the Egyptian cult

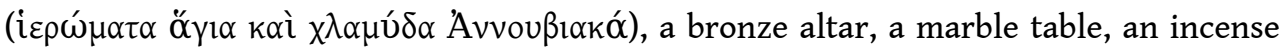

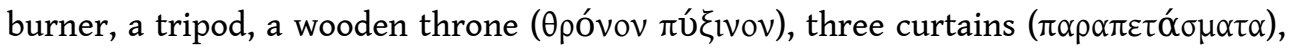
15 statuettes, and a glass krater. A dedicatory epigram for a statue of Dionysos, commemorating the victories of the flutist Ariston (519), presents the statue speaking:

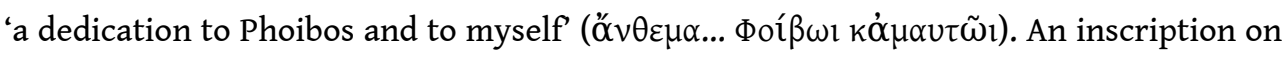
an altar narrates that M. Aelius Sabinianus, the most prominent Koan of the 2nd cent. 
CE, found an old image of Aphrodite, dedicated by Kallistrate, restored it and preserved

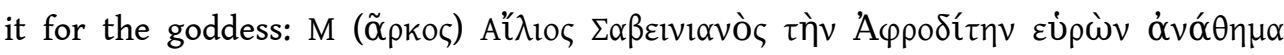

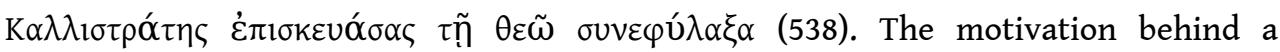

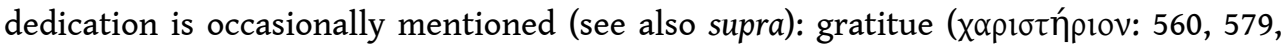

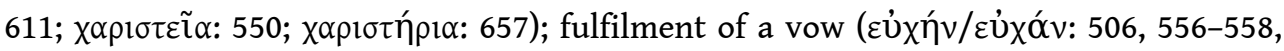

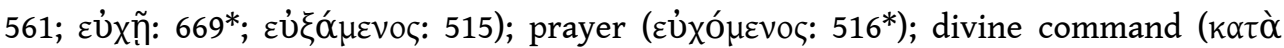

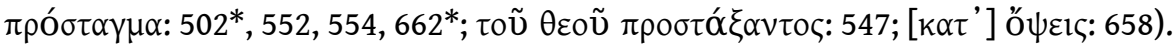

Ruler cult: An agonothetes, possibly of the Ptolemaia of Kos, dedicated a statue of Arsinoe II Thea Philopator (971). The cult of King Eumenes is attested through its priesthood (978). Imperial cult: Evidence for the imperial cult is provided by dedications to emperors and references to a variety of priesthoods. A fragmentary inscription lists the priesthoods of an anonymous man (1053). In addition to serving as priest of Hestia and the Pythokleian cults and priest of Apollo, he was priest or high priest of members of the Julio-Claudian dynasty: priest of Iulius Caesar, Tiberius, and Caius Caesar, and high priest of Claudius (1053). $\mathrm{n}^{\circ} 822$ mentions sacrifices to the emperors ( $\dot{\varepsilon} \kappa \theta \dot{v} \sigma \alpha v \tau \alpha$

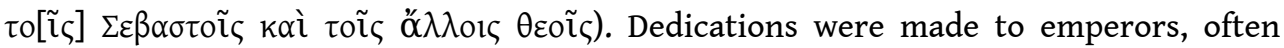
identified or assimilated with traditional gods: Augustus (633-635, 636*), Caius Caesar véoৎ $\theta \varepsilon o ́ \varsigma$ (637; dedication of a temple), Tiberius Zeus Capitolius Alseios (638, dedication

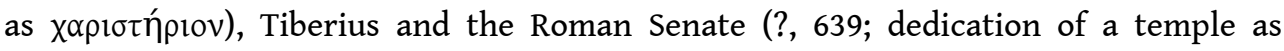

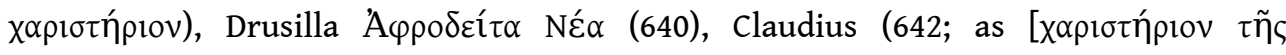
$\dot{\alpha} \sigma u \lambda i ́ \alpha] \varsigma ; 643$, a temple), Claudius Zeus Soter and Agrippina Demeter Karpophoros (643; cf. 1182), Nero Asklepios Agathos Theos (644-645, 646*; cf. 999 and 1055*), the emperors (650 and 1188: $\tau \grave{o} \beta \tilde{\alpha} \mu \alpha)$, an emperor identified with Zeus Stratios (648), a female member of the imperial family identified with Aphrodite (892), and anonymous emperors $\left(647,649^{*}, 651,652\right)$. As regards the identification of emperors with gods, we also mention a statue of Sebastos Apollo Kalymnios (i.e. Claudius, 894*), the identification of Augustus with Apollo Sebastos (1157), of Iulia with Leto (1155: 'Tou $\lambda$ í $\alpha v$ $\Sigma \varepsilon \beta \alpha \sigma \tau \alpha \grave{v} v \Lambda \alpha \tau o ́ i ̈ v ~ \kappa \alpha \lambda \lambda i ́ \tau \varepsilon \kappa v o v)$, Drusilla with Sebasta Homonoia (1159), Caligula with

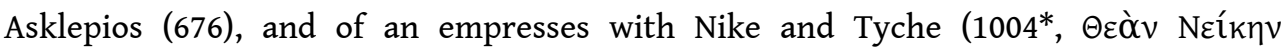

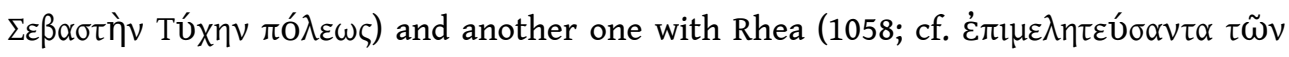
$\tau \tilde{\alpha} \varsigma \Sigma \varepsilon \beta \alpha \sigma \tau \tilde{\alpha} \varsigma$ 'Pع́ $\alpha \varsigma$ i $\varepsilon \rho \tilde{\omega} v)$. [An honorific inscription of Halasarna for Iulia may be

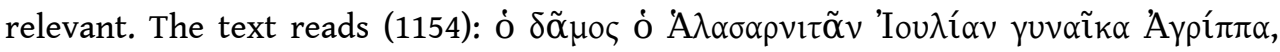

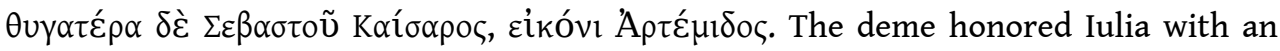
image of Artemis, thus attributing to her Artemis' properties. In the same way, a poetess was not honored with the erection of her own portrait statue but with the

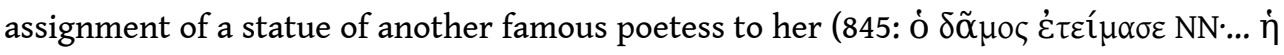

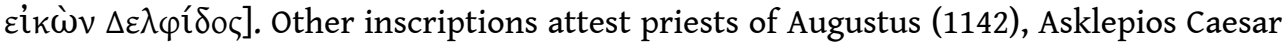
(Nero?, 999), Tiberius, (838), Tiberius, Claudius and the Demos (822), Trajan (898), and the emperors $(638,822,1162)$, a high priestess of Claudius for life (844), and a high priestess of an empress for life (887). C. Stertinius Xenophon, the physician of Emperor Claudius served as the emperor's priest for life (951, 952, 1143; for his other priesthoods, see infra). A Koan was designated as high priest of Thea Rhome and Caesar Augustus Zeus Patroios in Asia (951). An inscription from Antimacheia is dated with

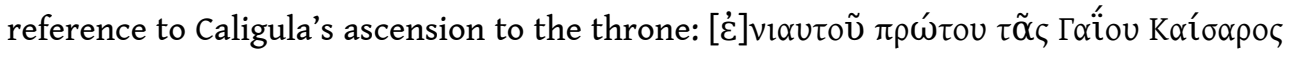

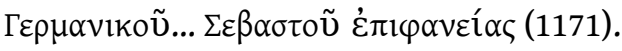

Cult personnel: The diversity of cult officials and their duties is revealed by the various priesthoods, offices, and services that are mentioned in honorific inscriptions, lists of 
magistrates, and dedications. The responsibilities of $\dot{\alpha} \rho \chi \varepsilon \cup \operatorname{v} \sigma \alpha \nu \tau \varepsilon \zeta$ included the offering of sacrifices to the Nymphs and a banquet to the citizens (456, 3rd cent.; references to $\dot{\alpha} \rho x \varepsilon v ́ \sigma \alpha \nu \tau \varepsilon \zeta$ also in 457). C. Stertinius Xenophon accumulated many priesthoods, serving as priest for life in the cults of the emperors, Asklepios, Hygieia, and Epione (951, 952, 1143), Kos and Merops (952), and Isis and Sarapis (952); he also held the

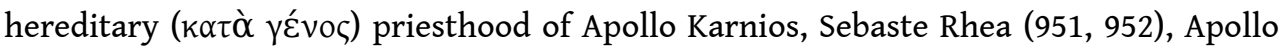
Pythios (952), Apollo Dalios (952), Zeus Polieus and Athena Polias (952), the Megaloi Theoi (952), Hera Elia Argia Basileia (952), the Nikomedeian gods (?, 952), and Aphrodite Pontia (952); he was also priest of an emperor, the Twelve Gods, Herakles, and Hestia (952), and is referred to in an inscription as high priest of the gods (1143; cf. 826 and 1146). Other Koans who accumulated priesthoods are a man who served as priest of Zeus Olympios and Zeus Epopsios (1054); a priestess of Asklepios, Hygieia and Epiona, Rhea, the Twelve Gods, Zeus Polieus and Athena Polias, Tiberius, Apollo Dalios, and Apollo Karneios (838); a priest of Asklepios, Asklepios Kaisar Sebastos, Hygieia and Epione (1055*); a priest for life of Tiberius, Claudius, and the Demos, hereditary priest

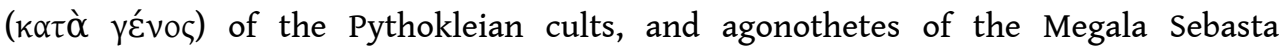
Asklepieia (822); a priestess of Asklepios, Hygieia, Epiona, Apollo Dalios, Lato, and king Eumenes (978); a priest of Apollo Dalios, Zeus Polieus, Athena (Polias), and the Twelve Gods (998); a priest of Apollo and the emperors (1162). There are also references to a priest of Asklepios and Hygieia $\left(1057^{*}\right)$, a priest of the ephebes (821), a priestess of Hera

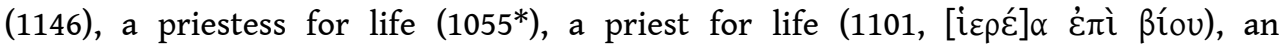

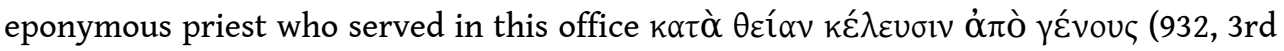
cent. CE), a high priest and priest (1146), a priest (1148), and priestesses $\left(846,851^{*}\right)$. Other cult officials: hierokaryx $\left(1136^{*}\right)$, hierotamias $\left(665^{*}, 1143\right)$, hierophylax (674), hieropoios (835), napoai in Halasarna $(1159,1161,1163,1164)$.

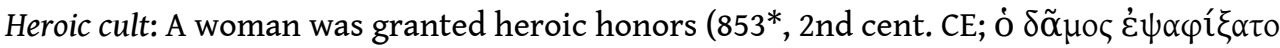

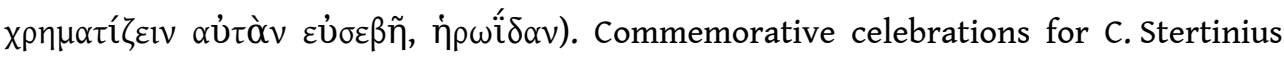
Xenophon, the ñ $\rho \omega \varsigma$, were held generations after his death (1184). One of his

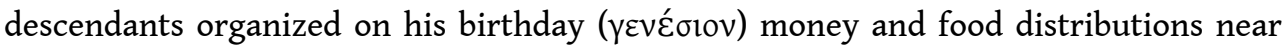

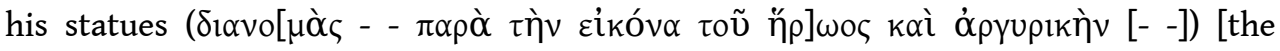

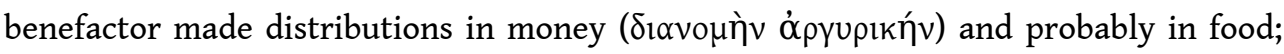

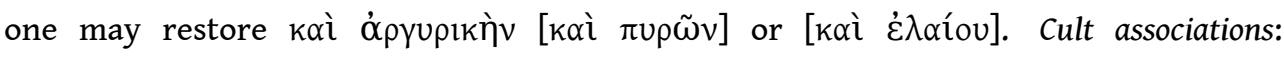
Serapiastai (605), Athenaistai Lindiastai and Dii Atabyriastai (654), eranistai Eisiastai (1027). Varia: Families of Kos claimed descent from Herakles (841) and Asklepios (841,

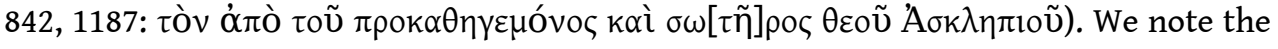

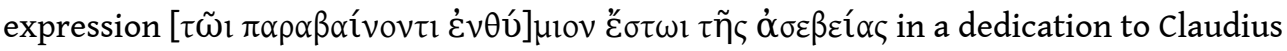
(642) [those who damaged the dedication would be liable to divine punishment for

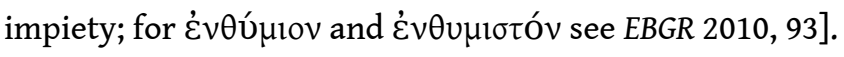

25) D. вотеVA, “The 'Thracian Horseman' Reconsidered", in Early Roman Thrace, p. 85105: The author argues that the Thracian Rider figure should be interpreted as a messenger, as a mediator between the mortals and the immortals. The votive reliefs show the hero communicating with a snake-god through an altar. In her interpretation, the arched upper side of almost all relief plaques alludes to the shape of tumuli. This suggests a connection between the votive plaques of the Thracian Rider and the funerary cult (cf. IGBulg III 1422). B. also advocates making a distinction between dedicatory reliefs with the Thracian Rider and funerary reliefs with the hero equitans, 
found in Greek colonies of the Black Sea. The finds from a sanctuary near Sivnica show that the cult of the Thracian Rider continued well into the 4 th cent. CE.

26) V. воттеZ, "Kebriones and Odysseus on a Graffito Discovered at Histria (Costanţa County, Romania)", in M.V. ANGELESCu et al. (eds.), Antiquitas Istro-Pontica. Mélanges d'archéologie et d'histoire ancienne offerts à Alexandru Suceveanu, Cluj-Napoca, 2010, p. 4349 [BE 2011, 451; SEG LX 782]: Ed. pr. of an ostrakon made from a fragment of an Ionian bowl; an inscription was engraved in poor calligraphy after firing (Histria, late 2nd/ early 1st cent.). The text consists of the names of Homeric heroes involved in the

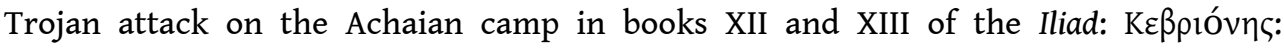

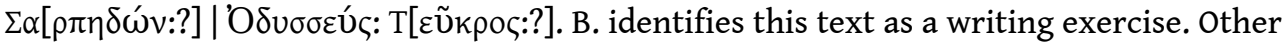
epigraphic finds from the Greek colonies of the west Pontic region show the importance of Homeric poetry in education and intellectual life (I.Tomis 386; IGDOP 42; SEG LIX 796). Ostraca with lists of divinities from Iliad XX and parts of the Catalogue of Ships (Iliad II) have been found in Egypt.

27) R. Bouchon, A. tZiafalias, “Consolations anonymes à l'occasion de la mort du jeune Markellos de Trikke", in AEThStE 3, p.495-503: Ed. pr. of a very interesting but fragmentary letter from Trikke in Thessaly (early 2nd cent. CE). The letter is addressed to the Thessalian Koinon by an anonymous community (Athens?) offering consolation to the federation and to the relatives of a certain Markellos for the young man's death. The text refers to a public funeral, during which his body was carried by the ephebes

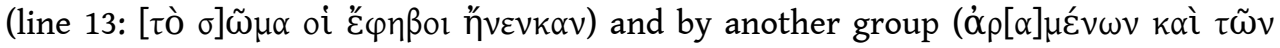
$\pi \alpha \rho^{\prime} \dot{\eta} \mu \varepsilon \tilde{\imath} v \sigma \varphi o ́ \delta \rho \alpha$

EN[- -]) [on this practice see EBGR 2006, 26]. The eds. argue that Markellos was a student of oratory, who died in Athens in the early years of the foundation of the Panhellenion

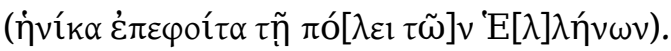

28) S. BRACKMANN, "Ein Votivtäfelchen mit einer ungewöhnlichen Weihinchrift für Zeus", ZPE 178 (2011), p. 221-222: Ed. pr. of a small bronze plaque in the shape of a tabula ansata, with two suspension rings (unknown provenance, probably from Asia Minor; offered for sale by Gerhard Hirsch Nachfolger, Munich). According to an inscription, the plaque was dedicated to Zeus Kraouandaseon by a man in fulfilment of a vow (Imperial period). This is the first attestation of this cult.

29) A. BRESSON, "An Introduction to the Funerary Inscriptions of Apameia", in L. SUMMERER, A. IVANTCHIK, A. VON KIENLIN (eds.), Kelenai-Apameia Kibotos. Développement urbain dans le contexte anatolien, Bordeaux, 2011, p. 295-308: B. discusses the main features of epitaphs in Apameia/Kelainai. Among the grave epigrams, we note a Late Hellenistic epitaph (MAMA IV 362), in which a son compares his parents to the gods:

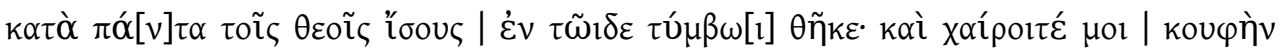

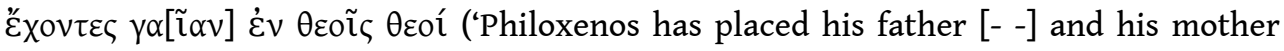
Ammia, they who in all aspects are equal to gods, in this tomb. And may you be pleased with me, because as gods among gods earth is to you light') ['gods among gods' reflects ideas of immortality of the soul, without necessarily implying initiation in a particular cult]. Another interesting epitaph (SGO III 16/04/03, Imperial period) has been though to reflect Christian ideas (because of the reference to a prayer), but B. rightly rejects this interpretation: 'I, Apphia, lie here, together with my husband Menekles; for when we were alive this was also our privilege. We have left two children, the younger one being Artemidoros, who out of piety has built this tomb for the dead. Farewell, passers-

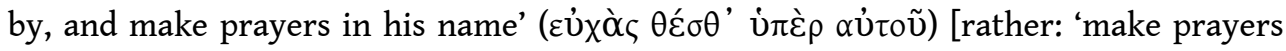


for his sake']; 'the prayers in favor of a son who had rightfully performed his duties towards his parents could fit well with pagan religion' (p.301). [This text is an interesting testimony of strong affection, both between husband and wife, united in death as in life, but also between parents and son. Even in death, the parents request the passers-by to pray for their son. Of course, in realty, the one who requests the prayers is the son, not the dead parents]. B. presents examples of funerary imprecations in pagan, Christian, and Jewish contexts (the formulaic phrases tòv

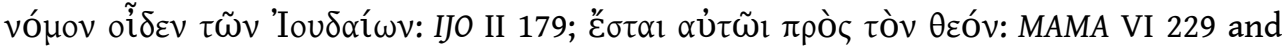

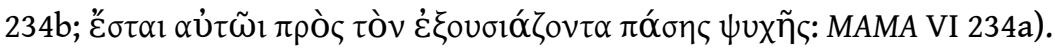

30) L. BRICAULT, "Une statuette d'Hermanubis pour Arès", in Bibliotheca Isiaca II, p. 131135: B. discusses a bronze statuette of Hermanoubis (2nd/3rd cent.), of unknown provenance, offered for sale in New York (Royal-Athena Galleries, Art of the Ancient World XIV, New York/London 2003, $\mathrm{n}^{\circ} 45$ ). According to an inscription on the base, the statuette was dedicated by a man and a woman to Ares. The personal names of the dedicants suggest a provenance from south Asia Minor. B. argues that the fact that the object was dedicated to Ares, confirms the conception of Hermanoubis as 'divinté psychopompe, qui écoute et exauce les voeux de ceux qui s'adressent à elle'.

31) L. BRICAULT, "Poids de Byblos inscrits au basileion", in Bibliotheca Isiaca II, p. 137-143:

B. collects lead weights of Byblos which are decorated with the basileion of Isis (3rd/2nd cent.). They provide evidence for the reception of Isis as a patron of the city [and maritime trade].

32) L. BRICAULT, "RICIS. Supplément II", in Bibliotheca Isiaca II, p. 273-307: B. presents bibliographical supplements and corrigenda to his Recueil des inscriptions concernant les cultes isiaques, Paris, 2005, that we briefly presented in EBGR 2005, 22. On p. 299-307, he presents inscriptions that had not been included in his corpus. We only mention the few texts that have never been presented in EBGR. Demetrias: A graffito on a vase, found in a deposit near the palace, designates the vase as a dedication to Isis $(112 / 0708=S E G$ LIII 525). Philippi: A Latin inscription from Doxato mentions a priest of Isis (113/1013). Kyrene: A dedication to Sarapis and Isis (701/0111).

33) W. BURKERT, "Genagelter Zauber. Zu den Ephesia Grammata", ZPE 183 (2012), p. 109110 [BE 2013, 47]: B. discusses a passage in the new phylactery in the Getty Museum

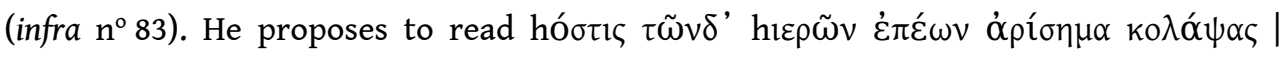

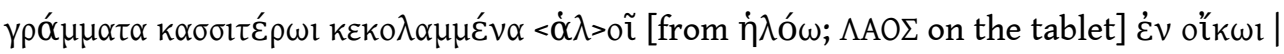

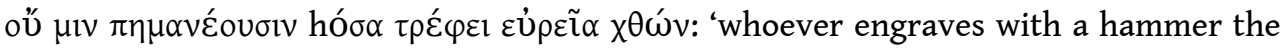
letters of these sacred verses, impressed with hammer on tin, and fixes them with nails in a house, will not be harmed by whatever is nourished by broad earth'. [But see the objection of M. SÈVE, BE 2013, 47: the aspiration sign is consistently written in this tablet; one would expect h $\alpha \lambda$ oĩ].

274 34) A. CALAPÀ, "Due dediche a sovrani tolemaici da Efeso e l'espansione tolemaica in Ionia negli anni settanta del III secolo a.C.", Studi Ellenistici 24 (2010), p. 197-210 [BE 2011, 511; SEG LX 1152]: C. republishes and discusses two dedications from Ephesos: a dedication to King Ptolemy, Queen Arsinoe, Sarapis, and Isis (I.Eph. 199 = SEG XXXIX 1232 and XLIII 749); and a dedication to Ptolemy, Arsinoe, and the Soteres by an officer and soldiers (SEG XXXIX 1234). She attributes both inscriptions to the reign of Ptolemy II and Arsinoe II (ca. 279-272) and discusses Ptolemaic influence in Ephesos in this period. [P. HAMON, BE 2011, 511, suggests that the dedicants of the second inscription 
were the Ptolemaic garrison soldiers in the citadel, i.e. in Bülbüldag. [A. MEADows, "Two 'Double' Dedications at Ephesus and the Beginning of Ptolemaic Control of Ionia", Gephyra 10 (2013), p. 1-12, dates the dedications to the reign of Ptolemy IV, possibly

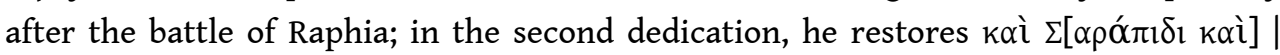

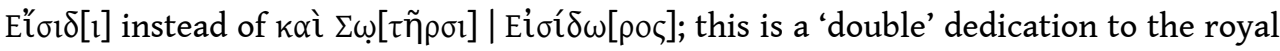
couple and Sarapis and Isis; he collects further examples of such 'double' dedications].

35) S. CAMPANELl, "Tra epigrafia e topografia: su una recente ipotesi di identificazione del santuario di Eracle Diomedonteios a Cos", Scienze dell'Antichità 17 (2011), p. 643-685: C. rejects the hypothesis expressed by L. DE MATTEIS, Mosaici di Co. Dagli Scavi delle missioni italiane e tedesche (1900-1945), Athens, 2004, p. 103-105 and 191-196, that the Herakles sanctuary found in the harbor of Kos (mentioned in IG XII 4, 320 and 302) should be identified with the sanctuary of Herakles founded by Diomedon (IG XII 4, 348). The former was a public sanctuary founded immediately after the synoecism of Kos in 366 $\mathrm{BCE}$, whereas the sanctuary of Diomedon was a private sanctuary. It was probably located in the countryside. The celebration of weddings mentioned in this inscription cannot be used as evidence for the role of Herakles as a patron of marriage in Kos.

36) S. CAMPANelli, "Hiera kai bebala in un'iscrizione di Cos. Lessico epigrafico e legislazione sacra", in Omaggio - Lombardi, p. 83-95: An inscription from Kos (IG XII 4, 349 , 2nd cent) provides details for the administration of a foundation established by Pythion for the worship of Artemis, Zeus Hikesios, and the Theoi Patrioi. One of the clauses describes the duties of a manumitted slave entrusted with the supervision of

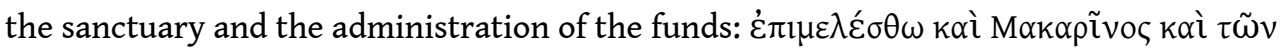

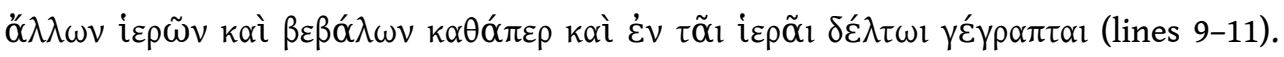
After a study of related expressions, C. concludes that $\beta \varepsilon \dot{\varepsilon} \beta \alpha \alpha \alpha / \beta \varepsilon \dot{\varepsilon} \beta \lambda \alpha$ refers to the proper use of the endowment for non strictly cultic purposes, e.g., the exploitation of the endowed real estate.

37) S.C. CANEVA, "Queens and Ruler Cults in Early Hellenism: Festivals, Administration, and Ideology, Kernos 25 (2012), p. 75-101: This study is dedicated to the rather neglected subject of cults of Hellenistic queens, examining the relevant epigraphic and papyrological sources for the cults of Berenike I, Arsinoe II Philadelphos, and Laodike IV [on Laodike, cf. infra $\mathrm{n}^{\circ} 210$ ]. With regard to the cult of Arsinoe, inscriptions and papyri show a successful synergy between the official promotion of her cult and private devotion. C. examines in detail the cultic aspects (festivals, selection of sacrificial animals, association between queens and goddesses), the appointment of priests and priestesses (kanephoroi), and the ideological significance of these cults.

278 38) J.-M. CARBon, V. PIRENNE-Delforge, “Beyond Greek 'Sacred Laws”, Kernos 25 (2012), p. 163-182: After reviewing recent discussions of the notion and nature of texts that have been variably labeled as 'sacred laws', leges sacrae, and cult regulations, and pointing to the very heterogeneous character of such texts, the authors present the aims of a new Collection of Greek Ritual Norms. The new collection will be limited to texts that unambiguously concern ritual practice and performance, i.e. purity and sacrifice. Adducing many examples of normative inscriptions, they convincingly explain why the use of the notion of the 'norm' and the limitation to purity and sacrifice will permit a more coherent collection of inscriptions that will enhance the study of Greek religion.

39) A. CHANIOTIS, "Megatheism: The Search for the Almighty God and the Competition of Cults", in One God, p.112-140: Without denying the sporadic existence of genuine 
monotheistic ideas in intellectual circles of the Graeco-Roman world, this study argues that the term 'pagan monotheism' is misleading in as much as it reduces the quest for the divine to a question of quantity, whereas the textual evidence shows that we are primarily dealing with a question of quality. Important questions concerned the properties of the divine, effective way of communicating with divine powers, the proper form of worship, and the hierarchy among the gods. The term 'megatheism' designates an expression of piety which is based on the personal experience of the presence of god, represents one particular god as somehow superior to others, and is expressed through oral performances (praise, acclamations, hymns) that accompanied ritual actions. Exploiting the epigraphic evidence of the Imperial period, this study discusses the following subjects: the propagation of a privileged relationship between a community and a patron deity (e.g. I.Ephesos $24=$ LSAM 31; SEG XLIII 756); the dissemination of religious ideas through written texts, especially oracles such as the theosophical oracle of Klaros (SEG XXVII 933; cf. SEG L 1225 and LIII 1587); the acclamatory phrases heis theos ('one god', i.e. a god who is unique within a polytheistic system) and megas theos (e.g. SEG LI 613-631; SEG LIII 1344); the devotion to gods whose power is regarded as superior to that of others (e.g. IG XI ${ }^{2}$ 1, 1024; SEG L 1222); the idea that a superior god presides over a council of gods (SEG LVII 1186; BIWK 5) and is served by angels; and the significance of newly constructed epithets that elevate a god and present him as continually present. The epigraphic material reveals several recurring elements in the conception of the divine: the power, righteousness and efficacy of gods; their demand for continual public praise; their willingness to offer assistance; and their presence.

40) A. CHANIOTIS, "Constructing the Fear of Gods: Epigraphic Evidence from Sanctuaries of Greece and Asia Minor", in Unveiling Emotions, p. 205-234: Fear and hope were two emotions of fundamental importance for the 'emotional construction of god' (e.g. Lucian, Alexander, 8; Sextus Empiricus, Against the Mathematicians, 9, 54). These two

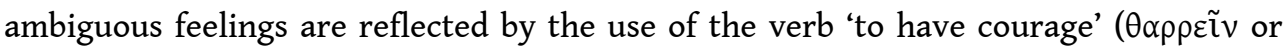
$\theta \alpha \rho \sigma \varepsilon i ̃ v)$ in narratives of human encounters with a god (e.g. I.Lindos 2 D; IG IV ${ }^{2} 1,128$ lines 63-68). The narration of emotional experiences accompanied by rituals was an important foundation of religious belief (e.g. SEG LVI 1434: the narrative of a man's fearful experience leads to the establishment of a cult of Great Zeus; cf. TAM II 174; Philostratos, Heroikos 16, 5-6). Also the fear of divine punishment for crimes, violations of sacred regulations, impiety, or anything else that might cause the anger of gods was omnipresent in Greek culture and dictated the public actions of communities, fearful of collective punishment (e.g. E. MEYER, "Eine Inschrift von Jolkos", RhM 8 [1936], p. 367-

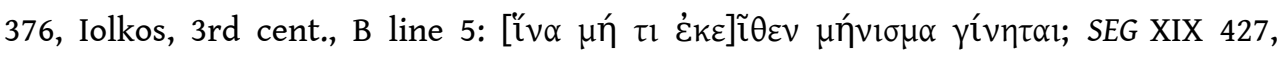
oracular enquiry of Dodona, 3rd cent.: 'has the god sent bad weather because of the

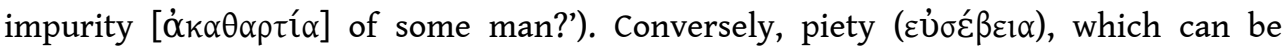
understood as fear of the divine ( $\delta \varepsilon 1 \sigma l \delta \alpha \imath \mu o v i \alpha)$, justifies hope for divine grace (e.g. LSCG Suppl. 14; RDGE 34 lines 11-15; IThracAeg E205). Inscriptions were important media for the propagation of these ideas and the arousal of the fear of punishment. The most important among them were oracular instructions and cult regulations (e.g. MERKELBACH/STAUBER, SGO I n ${ }^{\text {os }}$ 02/12/01, 02/12/03, 03/02/01; LSCG Suppl. 14; LSAM $20=$ TAM V 3, 1539; SEG XLIII 710), occasionally endorsed with curses (LSAM 16), the 'epigraphic memorials of divine justice' ('confession inscriptions' and other records of divine punishment; e.g. I.Leukopetra 53, 65; IG X 2 2, 233; BIWK 3, 5, 69, 98; SEG LIII 1344; LVII 1186), aretalogies and narratives of miracles (e.g. RICIS 302/0204), petitions for 
divine punishment such as the Knidian curses and funerary imprecations. Set up in sacred space, these inscriptions, often decorated with suggestive images and incorporated in rituals and oral performances (public reading, acclamations, oaths, curses), stimulated fear, hope, and gratitude. Texts and images set up in sanctuaries functioned as visual and acoustic signals that inspired the fear of god. These monuments also demonstrate the interdependence of attention, memory, emotion, cognition, and decision-making. Narratives of divine punishment written on stone and set up in sanctuaries preserved the memory of past events that had caused fear of god. Their decoration with reliefs attracted the attention of pilgrims. Their reading out loud, often in the context of rituals, aroused emotions: fear of divine punishment, hope of divine protection. And this founded a belief in the presence and power of god which guided decisions and actions.

41) A. Chaniotis, "Inscriptions", in C. RATtÉ, P.D. De staebler (eds.), Aphrodisias V. The Aphrodisias Regional Survey, Darmstadt/Mainz, 2012, p. 347-366 [BE 2013, 390]: Ed. pr. of inscriptions found during a field survey in the area of Aphrodisias. The most significant

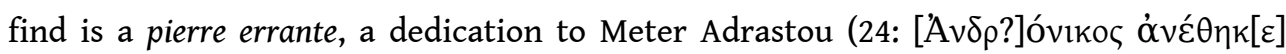

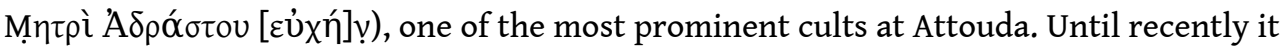

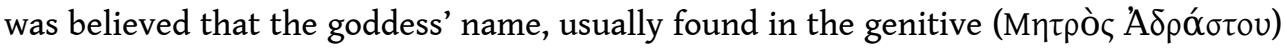

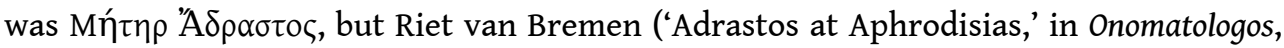
p. 447-449) has argued that Adrastos was the name of the founder of her cult (on 353f. a long list of divine names consisting of the personal name of the cult founder in the

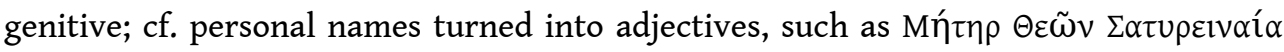

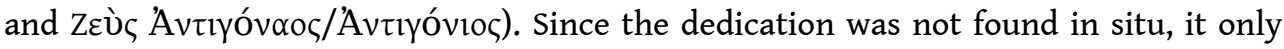
indirectly provides information concerning the location of Meter's sanctuary. The text of a dedication (?) on an altar or base $(3,3 \mathrm{rd}$ cent. CE) was partly destroyed when a

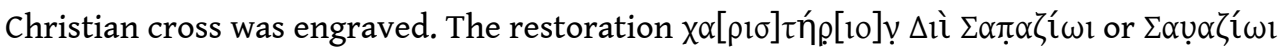
is possible but not certain. Two inscriptions on sarcophagi refer to the use of the fine

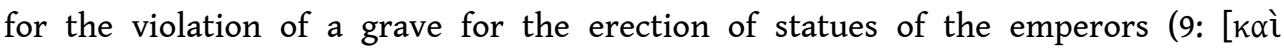

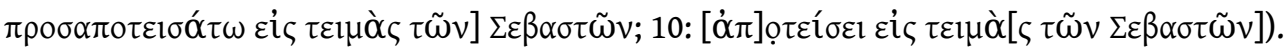

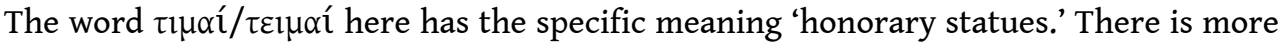
evidence for such use of fines in Aphrodisias (IAph2007 11.12; 11.29; 11.34; 13.156). One

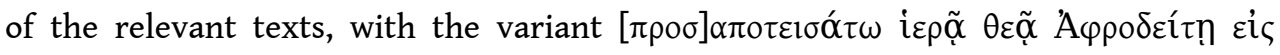
$\tau \varepsilon[1 \mu \alpha \grave{\alpha} \zeta] \tau \tilde{\omega} \nu \Sigma \varepsilon \beta \alpha \sigma \tau \tilde{\omega} v$ (SEG LVII 1016), suggests that the fine was paid to the sanctuary of Aphrodite, which was then obliged to use these funds for honorary statues of the

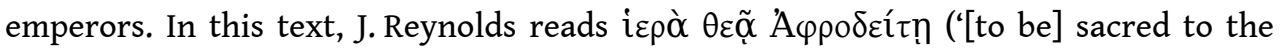

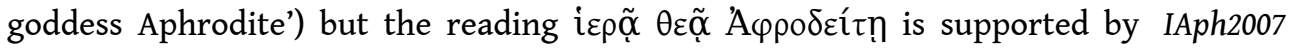

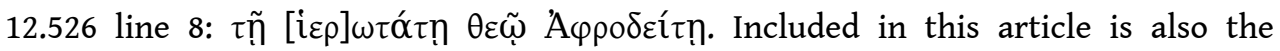
funerary epigram for Philadelphos (15) for which see EBGR 2010, 150.

42) A. ChAniotis, "Greek Ritual Purity: from Automatisms to Moral Distinctions", in P. RÖSCH, U. SIMON (eds.), How Purity is Made, Wiesbaden, 2012, p. 123-139: This study gives an overview of the way the idea of ritual purity developed from ca. 600 BCE to ca. 200 CE. Archaic and Classical sacred regulations concerned themselves with an ethically neutral pollution originating in physical processes, transmittable through physical contact, and removable through rituals focusing on the body. In the course of the Archaic period the law on homicide developed an elaborate idea of responsibility which influenced cult regulations. The idea of the purity of the mind was also promoted by religious movements interested in the immortality of the soul. Already in the fifth 
century BCE works of literature reflect the idea that the purity of the mind, the heart, or the soul should be aspired after, but cult regulations were rather slow in adopting it. A decisive part in this development may have been played by the cult of Asklepios and the belief in the interdependence of disease and sin, repentance and cure. From the second century BCE onwards sanctuaries increasingly demanded, in addition to the requirement of external purity, justice and piety, as well as pure and honest thoughts; in some cases they even warned that there were some sins for which one could never atone. It is argued that this development was part of a more general evolution of Greek attitudes towards rituals, from the belief that the efficacy of rituals depends on the correct and mechanical performance of prescribed actions ('automatism') towards an emphasis on moral distinctions. This evolution can be observed in measures for the exclusion of criminals from asylum, in the development of a new type of curses ('prayers for justice'), in moral requirements for initiation into mystery cults, and more generally in a tendency towards a priority of the word and the thought over the ritual action. Several cult regulations are adduced (LSCG Suppl. 91; I.Cret. I xxiii, 3; LSAM $20=$ TAM V 3, 1539; SEG XLIII 710; the temple inscription of Epidauros: Clemens of Alexandria, Stromateis V, 1, 13, 3; Porphyrios, de abstinentia II, 19, 5).

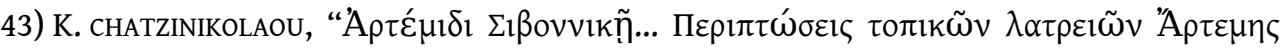

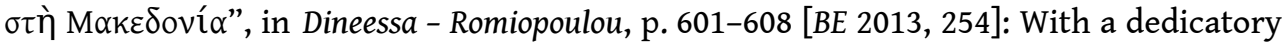
relief dedicated to Artemis Sibonnike (Orestis, Imperial period; SEG XLIX 772) as her starting point, C. collects evidence for local cults of Artemis in Macedonia, as indicated

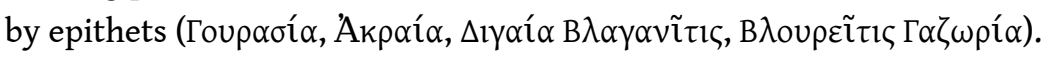

44) M. ChelotTI, "Brindisi e Augusto", in S. CAGNAzzi et al. (eds.), Scritti di storia per Mario Pani, Bari, 2011, p. 101-109: Discussion of the decree of Mytilene concerning the cult of Augustus (IG XII 2, 58), which C. dates to the period between the adoption of Caius and Lucius by Augustus and the death of Octavia (17-11 BCE).

45) P. CHRISTODoulou, "Les reliefs votifs du sanctuaire d'Isis à Dion", in Bibliotheca Isiaca II, p. 11-22: The author republishes 7 inscribed dedicatory reliefs found in the sanctuary of Isis at Dion (RICIS 113/0201-0203, 0205, 0206, 0217, 0219) and discusses in detail the iconography (representations of Isis, ears, and footprints), the date (2nd cent. BCE-early 3rd cent. CE), and the texts. We summarize the most significant new contributions. A relief dedicated to Sarapis, Isis, and Anoubis (p. 11-16 $\mathrm{n}^{\circ} 1$; SEG XLVIII 788; RICIS 113/0219; EBGR 1997, 177) is decorated with a representation of Isis who holds ears of wheat in her right and another object in her left hand; $C$. tentatively recognizes a bag filled with corn. Isis is represented as a goddess of fertility. A hole in Isis' hat was

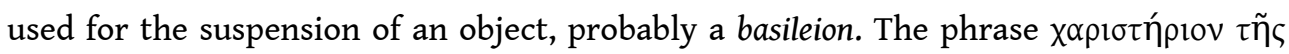
$\pi \lambda \alpha v \eta \tau \varepsilon \dot{\alpha} \varsigma$ was explained by M.B. Hatzopoulos as a reference to the wanderings of Isis. C. rejects this interpretation, since the dedication is not addressed to Isis alone, but to Sarapis, Isis, and Anoubis. In his view, it refers to the reason for which the dedicants were grateful, probably after a commercial trip ( $\pi \lambda \alpha v \eta \tau \varepsilon i ́ \alpha$; 'en marque de reconnaissance [pour les gains] du commerce par navire ambulant'; cf. SEG XL 1020: $\dot{\alpha} v \delta \rho \tilde{\omega} v v \alpha u \kappa \lambda \eta \dot{\eta} \rho \omega v \pi \lambda \alpha v \eta \tau \tilde{\omega} v)$. For this relief C. proposes a date in the early 3rd cent. CE. In a dedication to Hermanoubis (SEG XXXIV 625; RICIS 113/0206; p. 18-20 n ${ }^{\circ}$ 6), C.

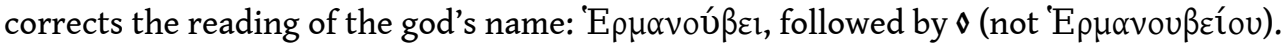
With regard to the footprints represented on reliefs ( ${ }^{\text {os }} 4-7$; RICIS 113/0201, 0203, 0205, 0206), C. notes the different size of the two feet. The difference in size cannot correspond to a difference in gender between two dedicants, since the inscriptions of 
these reliefs name a single individual as dedicant. The bigger footprint must be that of the divinity, the smaller that of the worshipper (p. 21f.).

46) N. çокВАNKIR, "Modrena ve Nikaia teritoryumundan yeni yazitlar", Olba 18 (2010), p. 323-345 [BE 2011, 575; SEG LX 1338-1339]: Ed. pr. of inscriptions from the territory of Nikaia (Imperial period). 6: A man dedicated an altar to Zeus Okonenos for his master in

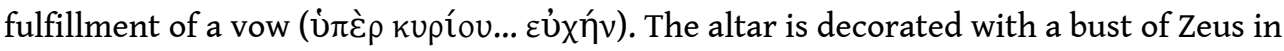
relief. Zeus Okonenos was already attested (I.Iznik 1118 and 1119); the cult may be of Thracian origin [V. SCHEIBELREITER-GAIL, in SEG LX 1339, notes that Zeus Okkonenos $\dot{\varepsilon} \pi \eta$ koo is attested in Thrace (SEG XXXII 679)]. 7: An altar was dedicated to the gods

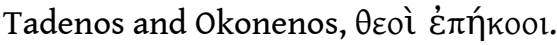

47) O. Coloru, "Themison, nipote di Antioco III", Studi Ellenistici 24 (2010), p. 273-280 [SEG LX 1574]: C. studies a dedication to Zeus Kasios for the well-being of King Antiochos III and his relatives from Aigeai (SEG XLIX 1943 = I.Anabarzos 31, 197 BCE). He identifies the dedicant as Themison, 'cousin' of King Antiochos III, grandson of Antiochos II and brother of Ptolemaios, the last dynast of Telmessos.

48) T. CORSTEN, O. HÜLDEN, "Zwischen den Kulturen. Feldforschungen in der Kibyratis. Bericht zu den Kampagnen 2008-2011", MDAI(I) 62 (2012), p. 7-117: Ed. pr. of the epitaph of a priestess of Aphrodite from Gölhisar Gölü, near Kibyra (1st/2nd cent.; p. 38f.).

49) C. CROWTHER, "CIG 2017: A Phantom Thracian Name and a False Corcyraean Provenance", in Onomatologos, p.464-469: C. presents an improved edition of a

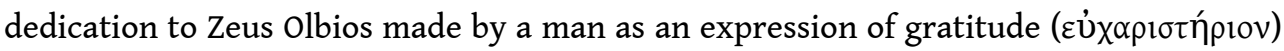
for his son's well-being (CIG 2017, Kyzikos, Imperial period).

50) L. D'AMORE, "Il corpo militare ateniese e il temenos di Apollo Liceo (IG I3 138). Un esempio di epikephal(a)ion telos?", in Omaggio - Lombardi, p.19-31: The Athenian decree IG I ${ }^{3} 138$ (ca. 449-434 BCE) obliges the Athenian soldiers, both citizens and

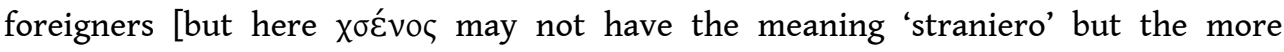
technical meaning 'mercenary soldier'] to pay a certain amount of money, that corresponds to a day's payment, to be used for a temenos of Apollo. This payment was a kind of epikephalaion telos to be distinguished from the due to be paid to Enyalios in Lindos (SEG IV 171 = LSCG Suppl. 85) [see EBGR 2008, 53]. The sanctuary for which the payment was made can be identified as the temenos of Apollo Lykeios, who was regarded as a patron of hoplites. D. discusses the administration of these funds by the city and associates this decree with the Periclean policy that promoted the use of public and private funds for public works.

291 51) J.-C. DECourt, A. tZiAfalias, "Un nouveau règlement religieux de la région de Larissa", in AEThStE 3, p. 463-473 [BE 2013, 237]: Preliminary presentation of an extremely important cult regulation from Marmarini in Thessaly. The ed. pr. of this text is presented in the present issue of Kernos and will be discussed in EBGR 2015.

52) I. DEKOULAKOU, "Le sanctuaire des dieux égyptiens à Marathon", in Bibliotheca Isiaca II, p. 23-46 [SEG LIX 198, 233]: D. presents a preliminary report of excavations at the sanctuary of the Egyptian gods in Marathon. In addition to a very interesting architecture, with a peribolos that had four Egyptianizing pylones decorated with statues (three male statues resembling statues of pharaohs, three statues of Isis), the finds include statues (inter alia, a sphinx, and a priest), lamps, and a small number of inscriptions. A fragmentary inscription (p. 36f.; late 2nd or early 3rd cent. CE) [SEG LIX 
198] mentions a man in the service of Sarapis. According to the restorations suggested

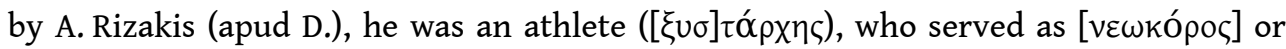

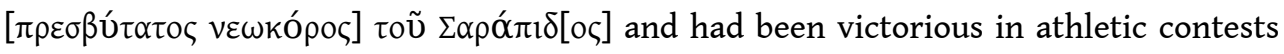

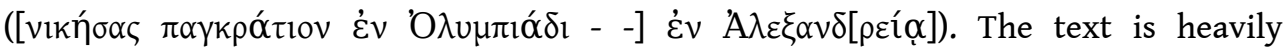
restored, but there are good parallels of xystarchs who held offices in the cult of Sarapis, e.g. M. Aurelius Ammonios (SEG XLI 1627) and M. Aurelius Asklepiades (IGUR

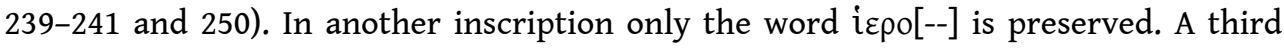
text is a dedication made by Polydeukes, the alumnus of Herodes Atticus, in expression

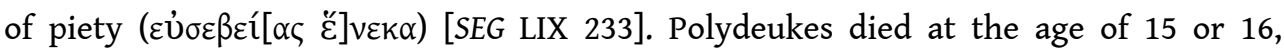
probably in 165 CE. Herodes Atticus owned land in Marathon. The sanctuary of the Egyptian gods can be identified with the sanctuary of Kanopos, where according to Philostratos (Vitae Sophistarum II, 554) Herodes met a certain Agathion, the 'Herakles of Marathon'. For other finds from the sanctuary see P. FOTIADI, "Ritual Terracotta Lamps with Representations of Sarapis and Isis from the Sanctuary of the Egyptian Gods at Marathon: the Variation of 'Isis with Three Ears of Wheat", ibid., p. 65-77; L. SISKOU, "The Male Egyptianizing Statues from the Sanctuary of the Egyptian Gods at Marathon", ibid., p. 79-95.

53) L. DEL MONACO, "Una lex sacra da Locri Epizefiri", in Omaggio - Lombardi, p. 31-42: A very fragmentary text on a bronze tablet found in a temple (of Zeus?) at Casa Marafioti in Lokroi Epizephyrioi (late 6th cent.; R. ARENA, Iscrizioni greche arcaiche di Sicilia - V, $\mathrm{n}^{\circ}$ 46; $L S A G^{2}$ p. $286 \mathrm{n}^{\circ} 1$ ) may be a cult regulation. This assumption is based on the

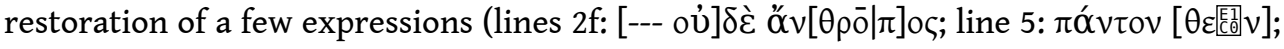

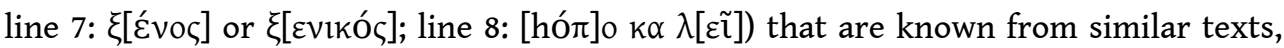
e.g. the cult regulation from Selinous (SEG XLIII 630) [cf. id., "Ancora sulla lex sacra dal tempio di Casa Marafioti a Locri”, in L. BREGLIA, A. MOLETI, M.L. NAPOLITANo (eds.), Ethne, identità e tradizioni: la "terza" Grecia e l'occidente, Pisa, 2011, p. 415-429].

54) L. DEL MONACO, “AEKI KATAEKI. Ephesia grammata da Locri Epizefirii”, ZPE 183 (2012), p. 129-139: D. observes that seven fragments from Lokroi Epizephyrioi are part of one and the same lead tablet (EBGR 1999, 41 and 2000,95). He identifies the text as a magical incantation, of which he presents a hypothetical reconstruction. One recognizes a

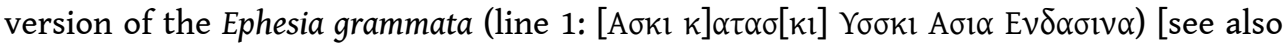

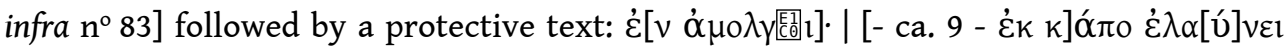

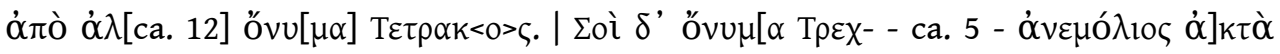

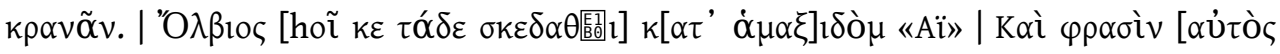

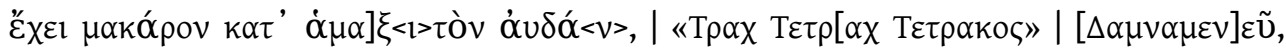

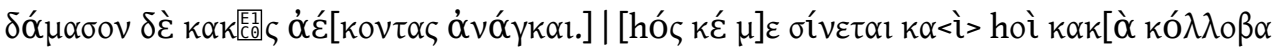

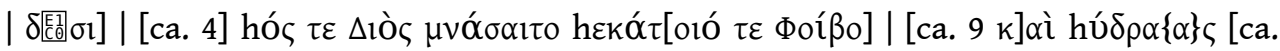
15]

55) O. DELOUIS, J.-P. GRÉLOIS, "Campagne de prospection 2008 de la mission Marmara. Annexe 2. Épigraphie", Anatolia Antiqua 17 (2009), p. 453-456 [BE 2011, 495]: D.-G. briefly present new epigraphic finds from Barakli, near Hadrianoi. The first fragmentary inscription $(146 / 7$ or $155 / 6$ CE) mentions a Bithyniarches [the eds. restore

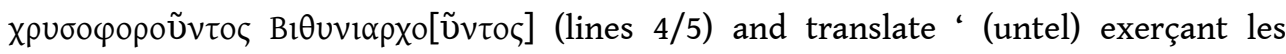
fonctions de chrysophore et de bithyniarque'; we should possibly restore

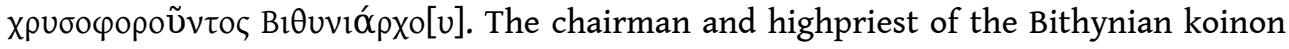

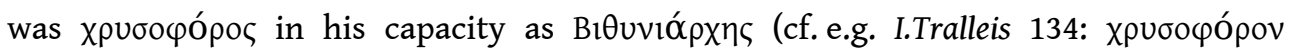




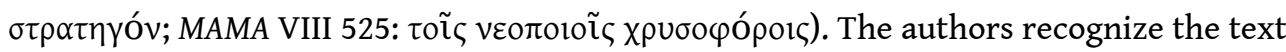

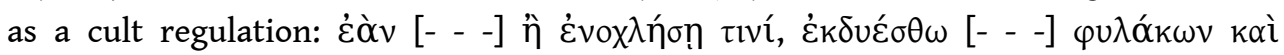

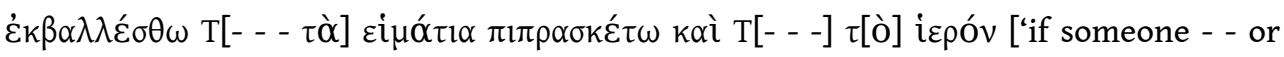
harasses anyone, let his/her garments be removed - - the guards, and let him/her be expelled (from the sanctuary) - - let the garments be sold - - the sanctuary'; cf. P. HAMON, BE 2011, 495, who recognized that the regulation concerns order in a sanctuary and prohibits the wearing of certain garments]. A second inscription (2, 2nd/3rd cent.) commemorates the erection of a statue ( $\dot{\alpha} v \delta \rho l \alpha ́ \varsigma)$ and an altar upon divine command

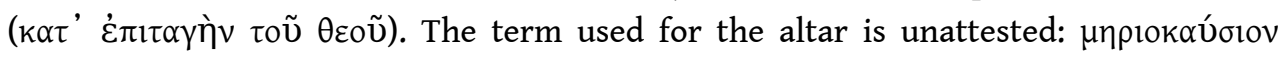
('altar on which the thighs of the victims are burned').

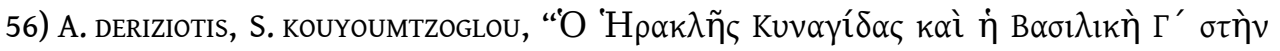

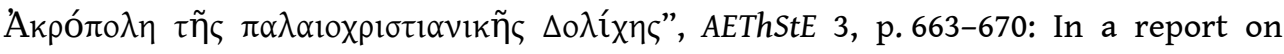
recent excavations in early Christian Doliche (Thessaly), D.-K. mention three important epigraphic finds that attest the existence of a sanctuary of Herakles Kynagidas in the citadel of Doliche; the exact location of this sanctuary has yet to be determined: 1) A proxeny decree for a man from Larisa, set up in the sanctuary of Herakles (late 3rd/ early 2nd cent.). 2) A dedication to Herakles Kynagidas made by his priest, after his term in office, and by three neokoroi (4th cent.). 3) A dedication to Herakles Kynagidas by Alexandros (3rd cent.).

57) R. DESCAT, “Autour de la tombe d'Hékatomnos. Nouvelle lecture d'une inscription de Mylasa", ZPE 178 (2011), p. 195-202: D. offers a convincing interpretation of a very fragmentary inscription from Mylasa (I.Mylasa 35, 4th cent.). It is a dedication to the Daimones Agathoi of the Karian dynast Hekatomnos and his wife Aba. It was made by a courtier of Maussolos, who had the court title grastapatis (an Iranian word). The dedication was made in the funerary monument of Hekatomnos.

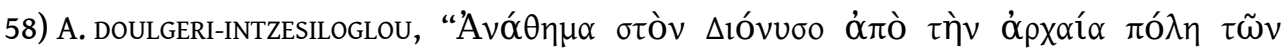

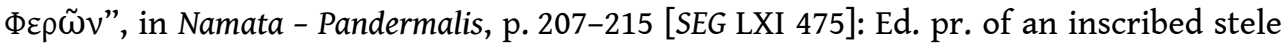
from Pherai (early 4th cent.). A hole on the front of the stele was used for the suspension of a metal object (a crown or another votive object). A dedicatory epigram, consisting of an elegiac couplet, is inscribed on the left narrow side: $\Delta \tilde{i} \varepsilon$ ụi $\kappa$ ' $\tilde{\omega}$

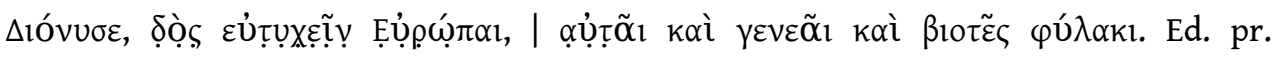
interprets ữ $\kappa$ ' as oĩ $k \alpha$ ('wherever you are'). The third line ([- - -]ẠEṬỌ[- - -]OḄ[-]TIKIBIOTEI $Y \Lambda A K I \Sigma)$ seems to repeat the text of the second line but in an imperfect manner. The cult of Dionysos was already attested in Pherai (SEG XXXIX 507). Europa, the dedicant, prays to Dionysos asking for happiness for herself, her family, and 'the guardian of her life'; this was a guardian, servant, or protector of her property; or more probably a personal agathos daimon (cf. Hesiod, Works and Days, 120-122). [The latter

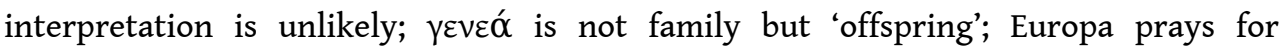
happiness for herself, her children, and her husband.]

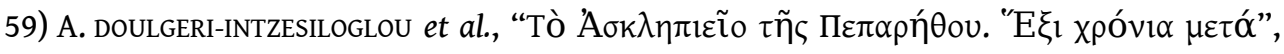
in AEThStE 3, p. 701-708: The authors report on the results of research conducted in the Asklepios sanctuary in Peparethos (Skopelos). This is the only Asklepieion known in the northern Sporades and one of the earliest in Greece, probably founded in the 5th cent. They mention the discovery of stamped tiles which are inscribed with the name of the

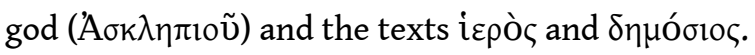


59 bis) M. DREHER, "Gerichtsverfahren vor den Göttern? - 'judicial prayers' und die Kategorisierung der defixionum tabellae", in Symposion 2009, p. 303-337: D., who is directing a project dedicated to Greek and Latin defixiones, presents his thoughts on the categorization of curse tablets and rejects the suggestion of H.S. Versnel and other scholars that there is a separate category of 'prayers for justice' [cf. id., "'Prayers for Justice' and the Categorization of Curse Tablets", in M. PIRANOMONTE, F. MARCO SIMÓN (eds.), Contextos Mágicos - Contesti Magici (Atti del Convegno Internazionale Roma 4-6 novembre 2009), Rome, 2012, p. 29-32]. For the main arguments and Versnel's response see infra $\mathrm{n}^{\circ} 200$.

60) T. DREW-BEAR, M. TÜRKTÜZÜN, "Goloe", in A.N. BILGEN et al. (eds.), Archaeological Research in Western Central Anatolia. The IIIrd International Symposium of Archaeology, Kütahya, 8th-9th March 2010. Proceedings, Kütahya, 2011, p.199-201: Ed. pr. of new inscriptions from Goloe (Northern Phrygia). They include a statue of Hadrian dedicated

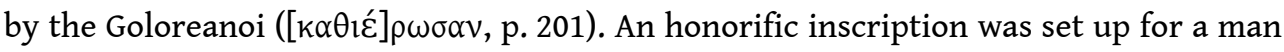
who served twice as priest (p. 201, 3/2 BCE).

61) A. DRUJININA, "Gußform mit griechischer Inschrift aus dem Oxus-Tempel", Archäologische Mitteilungen aus Iran und Turan 40 (2008), p. 121-135 [SEG LVIII 1686]: Ed. pr. of a clay casting mould for a large bronze vessel found in a pit in the area of the Oxos temple (Taxt-i Sangin, Bactria). The inscription, written in bad Greek by an indigenous man, reports that a bronze vessel weighing 7 talents was dedicated to Oxos, the local river-god. [The text in the edition of A.I. IVANTCHIK, VDI 279.4 (2011), p. 112-

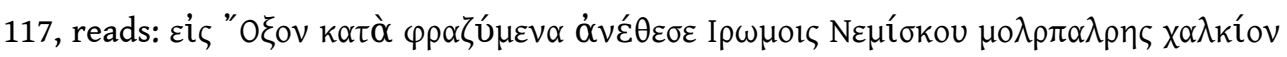
$\dot{\varepsilon} \gamma \tau \alpha \lambda \alpha{ }^{\alpha} v \tau \omega v \dot{\varepsilon} \pi \tau \alpha$ ('Iromois, [son of] Nemiskos, keeper of the seal, [dedicated] to Oxos a bronze cauldron weighing seven talents in accordance with a vow'). See also infra $\mathrm{n}^{\circ}$ 198].

62) D. elefterescu, "Two Gnostic Pieces from Durostorum", in Cultură şi Civilizaţie la Dunărea de Jos. Orient şi Occident, Călăraşi, 2011, p. 153-157 [An.Ép. 2011, 1135-1136]: Ed. pr. of a lead ring with the inscription I $\alpha \omega$ and an amulet with the inscription I $\alpha \omega \mid$ TPC on the obverse and ABRA|CAZ (for $A \beta \rho \alpha \sigma \alpha \xi$ ) on the reverse (Durostorum, Imperial period).

63) H. ENGELMANN, “Inschriften von Patara”, ZPE 182 (2012), p. 179-201 [BE 2013, 397]: Ed. pr. of 22 inscriptions from Patara in Lykia. 1) Ti. Claudius Flavianus Eudemos, a benefactor and statesman was honored posthumously (1, early 2nd cent. CE). He had served as a highpriest of the emperors and priest of the 'ancestral god' ( $\pi \alpha \tau \rho \tilde{\omega} 10 \varsigma$ $\theta \varepsilon o ́ \varsigma)$ Apollo [E. assumes that Eudemos was highpriest of the Lykian koinon but this is not explicitly stated in the text]. 2) The same man was posthumously honored with another inscription, which mentions building works in the theater, including the construction of a temple. 9) Iason was honored for serving as priest of the emperors in a pious,

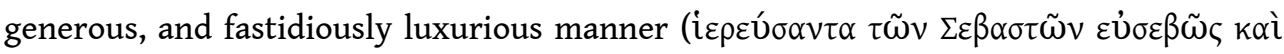

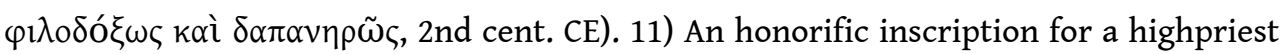

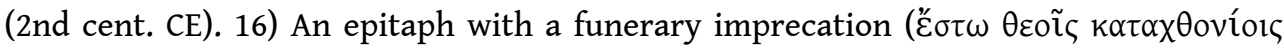
$\dot{\alpha} \mu \alpha \rho \tau \omega \lambda$ ó, 2nd cent. CE). 19) The epitaph of Euphrosynos, an alumnus of the city and

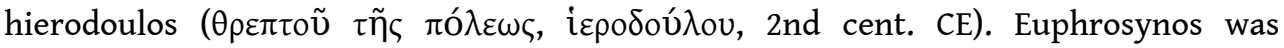
probably an orphan or exposed child, raised by the city, who later became a temple servant. 20) The long grave inscription of Marcia Aurelia Chrysion (ca. $250 \mathrm{CE}$ ) provides information on her family and her monumental grave. Chrysion was a daughter of the 


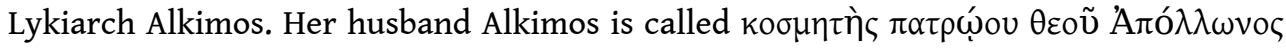
(an honorific title alluding to benefactions for the sanctuary of Apollo?) [rather, the designation of a religious office connected with a festival of Apollo; see infra $n^{\circ} 183$ ]. The grave monument ( $\dot{\eta} \rho \tilde{\omega} 10 v)$ consisted of a peribolos, within which there was a funerary temple ( $v \alpha o ́ \varsigma)$, where two sarcophagi were placed, a pronaos, and a grove (cf.

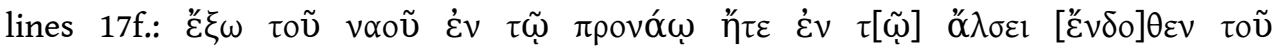
$\pi \varepsilon \rho ı \varepsilon \varepsilon 1$ í $\sigma \mu \alpha \tau о \varsigma)$. Chrysion had erected the grave for herself, family members, and the

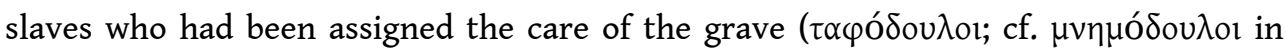
I.Arykanada 147). Chrysion had left an endowment of 250 denarii per annum for the maintenance of the grave. The text contains a long funerary imprecation: oi

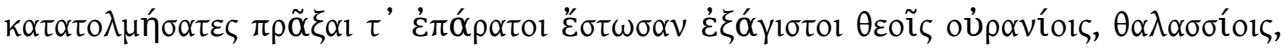

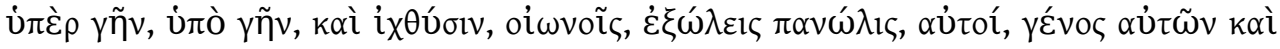

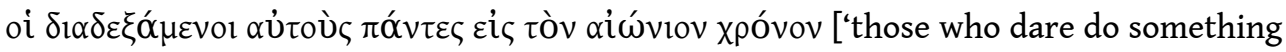
(against her instructions) shall be accursed and liable to punishment by the gods of the heaven and the sea, above the earth and under the earth, by the fish and by the birds, liable to total destruction and annihilation, they themselves, and their offspring, and all their succession in eternity'].

64) R. ERGEÇ, J.-B. YON, "Nouvelles inscriptions", in C. ABADIE-REYNAL (ed.), Zeugma III. Fouilles de l'Habitat (2). La maison des Synaristôsai, Lyon, 2012, p. 153-198 [BE 2013, 31]:

(Re)publication of inscriptions from Apameia and Zeugma. Apameia: A dedication to

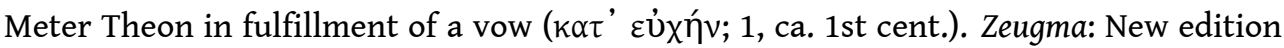
of SEG XXVI 1498, a fragmentary honorific inscription in which the phrase vooũ $\theta \varepsilon \tilde{\omega} v$ $[\pi \alpha] \tau \rho \omega \omega \omega v$ is preserved (2, undated).

65) C. FANTAOUTSAKI, "Preliminary Report on the Excavation of the Sanctuary of Isis in Ancient Rhodes: Identification, Topography, and Finds", in Bibliotheca Isiaca II, p. 47-63: F. summarizes the results of an excavation in the sanctuary of Isis in Rhodes. Although the cult of the Egyptian deities was known through epigraphic finds (cf. RICIS 204/0110/0111), the location of the sanctuary was not known. A still unpublished anatomical votive (a marble relief plaque with a female breast) was found in the

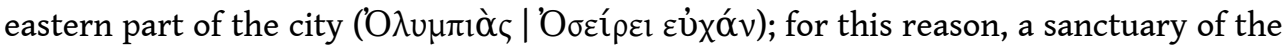
Egyptian gods was suspected in this area. The sanctuary, consisting of a peribolos, a temple, a crypt, and subsidiary structures, has now been identified at the eastern edge of the city, near the sea, just inside the south-eastern line of the fortification wall. The finds include statues and an inscription. The subject of the decoration of a marble relief

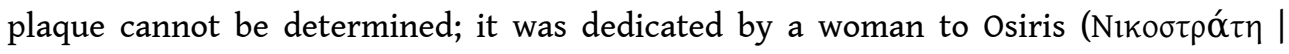

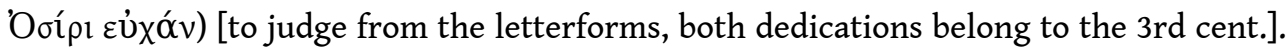
The temple was built in the early 3rd cent.; Rhodes was one of the earliest recipients of the cult of Isis and Sarapis.

66) P. FLouRENTZOS, “Ausgrabungen in der Unterstadt von Amathous", in K. LEMBKE (ed.), Zypern - Insel der Aphrodite, Hildesheim, 2010, p. 76-85 [SEG LX 1611-1612]. F. summarizes the results of recent excavations in the lower city of Amathous. On the basis of a dedication to Arsinoe II Philadelphos (SEG LVII 1736), F. assigns a temple excavated in the lower city to the cult of Arsinoe. He presents a new dedication to Tiberius [correct: Augustus; for the correct reading see supra $\left.\mathrm{n}^{\circ} 19\right]$ ]. This text and another dedication to Tiberius (mentioned by P. FLOURENTZOS, BCH 128/129 [2004/2005], p. 1661) suggest the existence in Amathous of a building complex dedicated to the 
imperial cult in general [see now also T. FUJII, Imperial Cult and Imperial Representation in Roman Cyprus, Stuttgart, 2013].

67) P. FRÖLICH, "Un décret de Messène accordant des honneurs post mortem", in J.-C. COUVENHES (ed.) L'hellénisme, d'une rive à l'autre de la Méditerranée. Mélanges offerts à André Laronde. De l'archéologie à l'histoire, Paris, 2012, p. 441-466: F. presents a new edition of a posthumous honorific decree for a benefactor, who died young (IG V 1, 1427, Messene, mid- or late 1st cent.). The decree provides for the participation of the entire community in his funeral, his crowning with a golden wreath, the construction of his grave monument in the city, the erection of a statue and the annual proclamation of the honors. The decree also mentions a sacrifice and the obligation of a priest (whose priest?), to provide a victim, probably for cultic honors offered to the anonymous benefactor. F. provides parallels for the honors, especially for the burial intra muros.

68) W.D. FURLEY, "Revisiting Some Textual Problems in the Delian Sarapis Aretalogy by Maiistas (IG IX 4, 1299)", ZPE 180 (2012), p. 117-125 [BE 2013, 328]: F. presents a new critical edition and translation of Maiistas' poem from the Sarapieion of Delos, in which the poet narrates the introduction of Sarapis' cult to Delos. [On this text and the evidence it provides for the introduction and development of the cult of Sarapis in Delos see I.S. MOYER, Egypt and the Limits of Hellenism, Cambridge, 2011, p. 142207 and 282-286 (text and translation)].

69) V. GABRIELSEN, "The Chrysaoreis of Caria", in Labraunda and Caria, p. 332-353: A close study of the documentation concerning the Hellenistic league of the Chrysaoreis (esp. SEG LIII 1229; I.Labraunda 43; I.Amyzon 16) leads G. to the view that it was a federal state and not simply a religious amphiktyony devoted to the cult of Zeus Chrysaoreus. The following cities were members: Mylasa, Amyzon, Alabanda, Alinda, Thera, Keramos, possibly Pisye, and another city ([--]na). In addition to cultic activities (an agonistic festival) and religious officials (hieromnemones), the Chrysaoreis had an assembly and were connected in some sort of sympoliteia.

70) L. GAWLINSKI, The Sacred Law of Andania: a New Text with Commentary, Berlin, 2012: G. presents a new critical edition, translation, and detailed commentary of the cult regulation of the mysteries of Andania (IG V 1, 1390; cf. EBGR 2006, 36). She discusses the

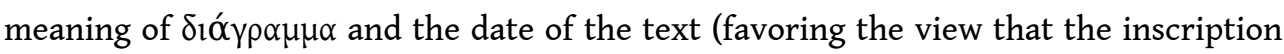
dates to the 55th year of the Achaian era, i.e. $91 \mathrm{BCE}$ ) [That Messene used the Actian era is securely attested by 18 inscriptions; by contrast, there is not a single piece of evidence that securely attests the use of the Achaian era. P. Themelis' view that the text dates to $24 / 23$ CE is further supported by prosopographical evidence (SEG LVII 364) and is far more plausible]. G. presents an excellent study of the topography of Andania and proposes a plausible reconstruction of the procession. In her thorough commentary, she discusses all aspects of the regulation, especially the clauses concerning garments, the arrangement of the procession, the order, and the financial aspects of the cult. [For some criticism in minor details, see my review in Gnomon 87 (2015), p. 275f.]. G. rejects the view of V. Pirenne-Delforge (see EBGR 2010, 155) that Mnasistratos, the driving force behind this regulation, gave to Messene a text that was not an ancient 'sacred book' but the result of his personal research (p. 104-106). [There is a good parallel for Pirenne-Delforge's view. Leon, priest of Zeus Panamaros, persuaded the city to upgrade

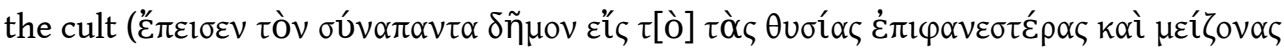
$\sigma \cup v \tau \varepsilon \lambda \varepsilon \tilde{\mathrm{i}}$ (I.Stratonikeia 7, ca. $200 \mathrm{BCE}$ ) by presenting the result of his study of ancient 


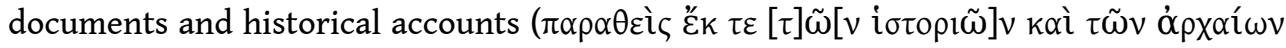
$\gamma \rho \alpha \mu \mu \alpha ́ \alpha \omega v)$. This may well be what Mnasistratos did in Messene].

71) W. GÜNTHER, "Neue Inschriften aus Didyma”, Chiron 42 (2012), p. 255-269 [BE 2013, 370]: Ed. pr. of two inscriptions from Didyma: Thrasys dedicated a dekate to Apollo (1, ca. 550-500 BCE); Aristagore dedicated a statue of her son to Apollo Didymeus (3, 3rd cent.). G. also presents an improved edition of a rediscovered inscription, hitherto known only from a copy by C.T. Newton: Histiaios dedicated a tithe to Apollo $(2=$ I.Didyma 14, late 6th cent. BCE). It is not certain whether the dedicant is the famous tyrant of Miletos at the time of the Ionian revolt.

313 72) L.-M. GÜNTHER, "Die Milesierinnen Tryphosa Apolloniou und Tryphosa, die Prophetin", in L.-M. GÜNTHER, V. GRIEB (eds.), Das imperiale Rom und der hellenistische Osten. Festschrift für Jürgen Deininger zum 75. Geburtstag, Stuttgart, 2012, p. 151-163: Examining the prosopographical evidence for Tryphosa, a hydrophoros of Artemis Pythie (I.Didyma 395, 41/40 BCE) in Miletos, the hydrophoros Platainis Tryphosa (SEG XXX 1286, ca. 110$115 \mathrm{CE}$ ), and her grandmother Tryphosa, who served as prophetis in ca. 5 CE, G. argues that all three women were related to the important Milesian family of C. Iulius Epikrates. The prophetis was expected to be an unmarried woman and to serve for life. Tryphosa, who was either married or a widow when she was appointed, was selected for this office in accordance with Apollo's oracle. Her service in this office may be connected with efforts of Miletos to upgrade the cult in Didyma and to achieve a neokorate in ca. $40 \mathrm{CE}$.

73) K. HALLOF, K. HERRMANN, S. PRIGNITZ, "Alte und neue Inschriften aus Olympia I", Chiron 42 (2012), p. 213-238: Ed. pr. of important finds from Olympia. 1) A statue, crafted by

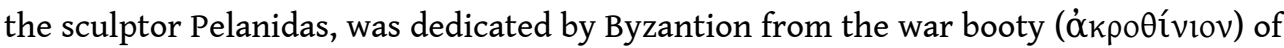
an undetermined war, either shortly before 513 or during the Ionian revolt of 499/8 BCE. Akpo日íviov is attested as a designation of war booty in the early Classical period (SEG XXIV 318-319; IG $\mathrm{I}^{3}$ 1463). 2) An inscription records the dedication of a statue of Autolykos of Elis by Argos (early 3rd cent.); the statue is signed by Daippos. 3) An inscribed base supported an honorific statue of Asamon of Elis; according to Pausanias VI, 16, 5, the statue was made by Pyrilampos. 4) A very fragmentary epigram probably honors the philosophers who were sent as envoys of Athens to Rome in 156/50. The authors also present an improved edition of an inscription that records the dedication of a statue of C. Caecilius Metellus by Hyampolis to the gods (SEG III 414, ca. 148-146 BCE); the inscription was found re-used in a church between Hyampolis and Kalapodi.

74) H. HAUBEN, "Ptolémée III et Bérénice II, divinités cosmiques", in More than Men, Less than Gods, p. 353-388: H. discusses the literary evidence for the 'lock of Berenike' and the Canopus decree as evidence for the way Ptolemy III and Berenike were presented as masters of time and 'cosmic divinities'.

316 75) P. IOSSIF, "Apollo Toxotes and the Seleukids. Comme un air de famille", in More than Men, Less than Gods, p. 229-291: After an exhaustive study of the numismatic and epigraphic evidence for the perception of Apollo as an archer and his association with the ruler cult of the Seleucids, I. argues that the motif of the archer has Assyrian and Achaemenid origins. The oracle of Didyma played an important part in the association of Apollo with the Seleucids (cf. I.Didyma 424, 479, 480). In this context, I. examines the

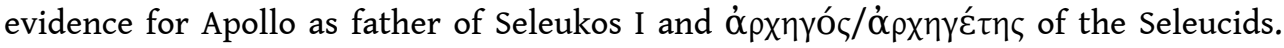
Since the date of OGIS 212 (Seleukos I or II?) and 219 (Antiochos I or III?) is disputed, 
I.Didyma 493 (under Seleukos II, 246/5 BCE) is the earliest secure attestation of this filiation. With regard to a hymn from Erythrai (I.Erythrai 205), in which a king Seleukos

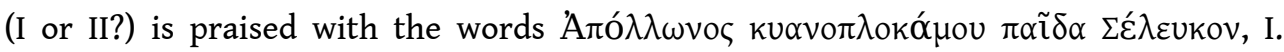
argues that the word $\pi \alpha \tilde{l} \varsigma$ may have the meaning 'servant'; in this case, the king is Seleukos II. [When ancient hymns refer to the descent of the god whom they praise,

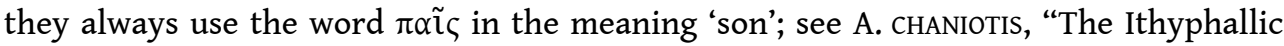
Hymn for Demetrios Poliorcetes and Hellenistic Religious Mentality", in More than Men, Less than Gods, p. 183. Here, there can be no doubt that the text refers to filiation, since it continues: ôv $\alpha$ ป̀ is the father of Seleukos, the king must be Seleukos I.].

76) S. ISAGER, "The Epigraphic Tradition at Labraunda Seen in the Light of Labraunda Inscription $n^{\circ}$ 134: A Recent Addition to the Olympichos File", in Labraunda and Karia, p. 199-215: I. republishes an honorific decree of Mylasa that establishes the cult of the Karian dynast Olympichos (EBGR 2008, 73) and sketches the development of the epigraphic tradition in the sanctuary of Labraunda from the 3rd cent. BCE to the Imperial period.

T) S. ISAGER, P. PEDERSEN, "Hadrian, Sabina, and Halikarnassos - Some Epigraphic Evidence", ZPE 181 (2012), p. 95-101 [BE 2013, 383]: Ed. pr. of a very fragmentary letter

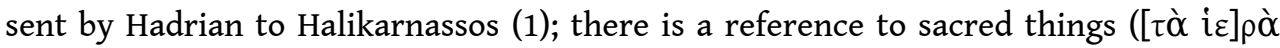

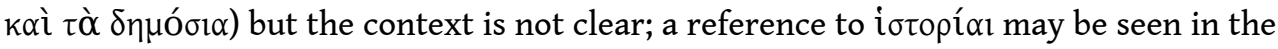
context of the interest in history inspired by the creation of the Panhellenion. The authors also publish a dedication to Hadrian found in 1990. The emperor is identified

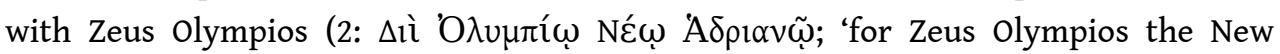

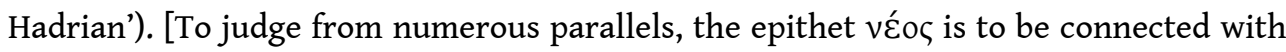
Zeus, not with Hadrian: 'For Hadrian, the New Zeus Olympios'; exactly as his wife Sabina was 'new Hera' (see below), Hadrian was 'new Zeus'; e.g. Iulia was praised as Nea Aphrodite (EBGR 2004, 42), Caius Caesar as Neos Ares (EBGR 1994/95, 131), Drusilla as Nea Charis (EBGR 2001, 75), Nero as Neos Apollon (EBGR 1994/95, 38), Hadrian and Caracalla as Neos Dionysos (EBGR 2008, 52 and 62), Hadrian as Neos Pythios (EBGR 2011, 29), Commodus as Neos Helios (EBGR 2004, 126), etc.]. Another dedication to Hadrian also identifies him with Zeus Olympios (3; G.E. BEAN, J.M. сооK, "The Halicarnassus Peninsula", ABSA 50 [1955], p. $105 \mathrm{n}^{\circ}$ 29). In this context, the authors reconsider an

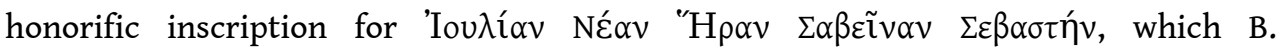
HAUSSOULLIER ("Inscriptions d'Halicarnasse", $B C H 4$ [1880], p. $396 \mathrm{n}^{\circ}$ 3) identified with the daughter of Emperor Titus. They suggest that the dedicants 'chose to raise the value of their dedication by adding an unofficial Iulia'. [The identification with the daughter of Titus should indeed be rejected; there was no foundation for her identification with Hera, whereas there were good reasons to associate Sabina, the wife of Hadrian, the New Zeus Olympios, with Hera. Sabina is in fact called Nea Hera in Thasos (IG XII Suppl. 440), Patara (TAM II, 412), and Tlos (TAM II, 560). I suspect that the addition of Iulia was influenced by dedications to Iulia, Augustus' daughter (e.g. Iulia Nea Aphrodite: IG XII 2, 482; Iulia Sebasta Lato: SEG LIV 753; Iulia Sebasta Nea Eileithyia: SEG XLVII 847), or Livia, who after Augustus' death was called Iulia Sebaste (e.g. Iulia Sebaste Artemis Boulaia: SEG XXII 152; Iulia Sebaste Hestia Nea Demeter: IGSK 6, 11). The author of the text applied a known formula by mistake, not as an unofficial title].

78) A.I. IVANTCHIK, S.R. TоKHTAS'EV, “Queen Dynamis and Tanais”, in E. PAPUCI-WEADYKA et al. (eds.), Pontika 2008: Recent Research on the Northern and Eastern Black Sea in Ancient Time, 
Oxford, 2011, p. 163-173 [BE 2010, 471; SEG LIX 860]: The authors present a new edition of a fragmentary inscription from Tanais (SEG XLV 1022), associating two further fragments with the published one. In their reconstruction, the inscription records a dedication made by the community of Tanais on behalf of Queen Dynamis (20 BCE-9 CE)

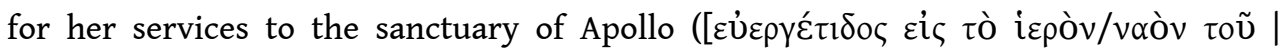
Ȧ ] AVRAM, BE 2010, 471]. For a Russian version see iid., VDI 270, 3 (2009), p. 95-100 $\mathrm{n}^{\circ} 1$. [V.P. YAYLENKO, Tysiacheletnij Bosporskij reich, Moscow, 2010, rejects this reconstruction and recognizes two separate dedications, one for Mithridates VI and one for Pharnakes].

79) P. IVERSEN "Inscriptions from Pisidian Konane (Conana) and the Surrounding Area", EA 45 (2012), p. 103-152 [BE 2013, 423; SEG LX 1479-1480]: Ed. pr. of two dedications found in the area of modern Isparta (ancient Konane) in Pisidia. A dedication was made to Zeus Epekoos in fulfillment of a vow (6, Gönen, 2nd cent. CE). A dedication is addressed to $\Delta i \grave{i} \Gamma \alpha \lambda \alpha \kappa \tau i ́ v \omega$ in fulfillment of a vow (29, Güneykent, 2nd cent. CE) [SEG LX 1480]. I. interprets this as a dedication to the 'milky-white' Zeus (cf. Zeus Galaktios in Lydia: TAM V 1, 32). [The correct reading is $\Gamma \alpha \lambda \alpha \kappa \tau \eta \nu \tilde{\omega}$, with a ligature of HN, not

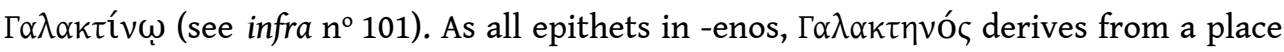
name Galakta, not from a property of Zeus]. I. also republishes a fragmentary dedication to Mes from Güneykent (2nd cent. CE, SEG XXXI 1280). He reads: [-]N[- - - -

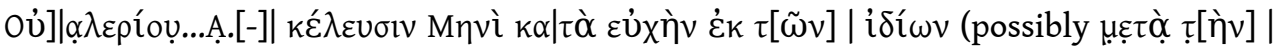

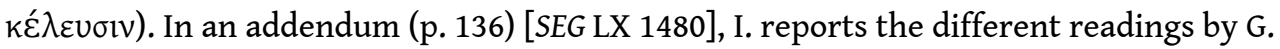

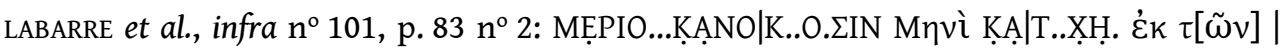

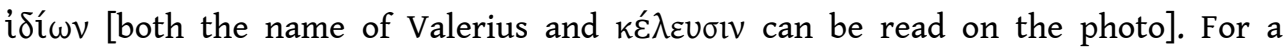
dedication to Zeus Nikator (p. 124f. $\mathrm{n}^{\circ}$ 31) see infra $\mathrm{n}^{\circ} 101$.

80) A. Jacquemin, D. mulliez, G. Rougemont, Choix d'inscriptions de Delphes, traduites et commentées, Athens, 2012 [BE 2013, 209]: This selection of Delphic inscriptions in reliable editions and translations is truly a quarry for information concerning the Delphic cult, dedications, cult regulations, the administration of the sanctuary, and the political role of the Delphic amphiktyony. The volume presents 300 inscriptions, all of them published. Naturally, private and public dedications to Apollo take the lion's share $(3-12,14-20,22,25,33-34,47-48,51-54,57,59,61,63,67,80,82,114,143,151-$ $153,160,178-180,187,210,214-220,228,261)$. There are only two dedications to other deities (Aphrodite Epiteleia: 159; Dionysos Sphaleotas: 171) but there is evidence for secondary cults (9-13: Eileithyia, Hygieia, Athena Ergane, Athena Zosteria, Zeus). Among the dedications we note a dedicatory epigram with which a man thanks Apollo for the birth of two daughters (59). We summarize the content of other inscriptions of religious interest according to subject matter. Cult regulations: prohibitions concerning wine consumption (23); an amphiktyonic regulation (27); the sacred law of the Labyadai (30); decrees concerning the value of the pelanos offered by Phaselis (26) and the participation of the Asklepiadai of Kos and Knidos (32); an agreement between Delphi and Skiathos concerning the participation of Skiathos in the Delphic cult (31). Festivals: documents concerning the celebration of the Pythais by the Athenians (198-205) and the Dodekais, i.e. probably the offering of the sacrifice of 12 victims by the Athenians (278-280); agonistic inscriptions (21, 50; documents related to the Soteria: 70, 79, 285286, 298); the honorific decree for Aristotle and Kallisthenes for the composition of a list of the victors at the Pythia (49); decrees concerning the activities and privileges of 
the Dionysiac technitai $(68-69,194-197)$; honorific inscriptions for poets $(122,123,282)$ and musicians $(186,189-190,192,208-209,283,287,289,298)$; a list of theorodokoi (125); a document concerning construction works in preparation of the Pythia (116); documents pertaining to the recognition of agonistic festivals (Ptolemaia: 73; Nikephoria of Pergamon: 154-155; Delphic Soteria: 78; Eumeneia of Sardeis: 163-164); decrees concerning the organization of the Eumeneia and Attaleia in Delphi (167-168); documents concerning the re-organization of the Pythia under Domitian (230-233); an endowment concerning the establishment of the commemorative sacrifice Alkesippeia (137). Hymns: hymns to various gods $(60,203)$. Oracular practices: grants of promanteia $(35,36,56,58,71)$; an oracle given to Kyzikos concerning a festival for Kore Soteira (91); an oracle given to Agamemnon (an ancient forgery; 171). Sanctuaries: documents concerning the reconstruction of the temple of Apollo in the 4th cent. (3745); a decree concerning livestock belonging to the sanctuary of Apollo in Delphi (157); a list of immobile property given to the sanctuary (144); documents concerning the asylia of Athena Itonia (74), the Pythaion of Kalchedon (75), the sanctuary of Aphrodite Stratonikis in Smyrna (81), Teos (86-89), Antiocheia of the Chrysaoreis (90), Delphi (145-147), and the sanctuary of Athena Nikephoros in Pergamon (154-155); use of sacred money for construction work in the sanctuary (234-239). The Delphic amphiktyony: honorific decrees for men for their services to the amphiktyony (92-102, 107-108, 138, 149); amphiktyonic decrees concerning cases of embezzlement of sacred money (99-100, 174-177); a verdict concerning the representation of East Lokris in the amphiktyony (183); a letter of Hadrian on amphiktyonic affairs (252); other amphiktyonic decrees $(117,118)$. Cult personel: an honorific statue for a priestess of Eileithyia (142). Manumission records: 127-136. Hero cult: a Delphic decree (237 = F.Delphes III 1, 466) establishes the heroic cult of Memmius Nikandros; prayers should be

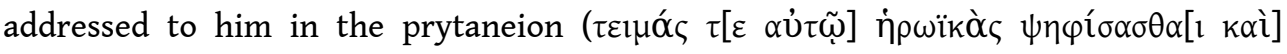

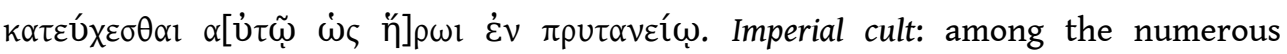
inscriptions in honor of emperors, we single out a dedication to Hadrian by the league of the Greeks who participated in the Eleutheria at Plataia: A

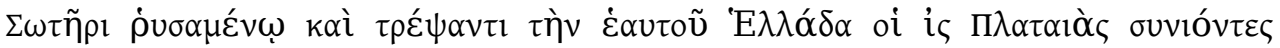

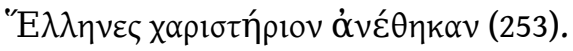

81) T.S.F. JIM, "Seized by the Nymph? Onesagoras the "dekatephoros" in the Nymphaeum at Kafizin in Cyprus", Kernos 25 (2012), p. 9-26 [BE 2013, 74]: K. studies the evidence provided by a large group of inscribed vases from Kafizin (225-218 BCE) for private piety (T.B. MITFORD, The Nymphaeum of Kafizin, Berlin, 1980). 269 out of 310 inscribed items were dedicated by Onesagoras, either alone or together with other individuals. Because of the similarity between Onesagoras' devotion and that of

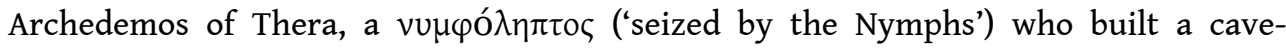
sanctuary for the Nymphs on Mt. Hymettos in the late 5th cent. (IG I' 977-980), and Pantalkes, who decorated a grotto near Pharsalos in Thessaly (SEG I 247-248; XVI 377-

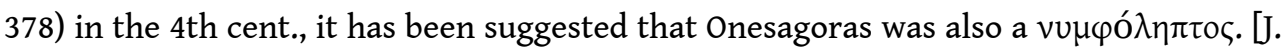
also includes in this group of devoted worshippers Artemidoros of Perge, who built a sanctuary in Thera (IG XII 3, 421-422; IG XII Suppl. 1333-1350); although his activities are a good example of private piety, they have nothing to do with either nympholepsy or particular devotion to one deity; see EBGR 1995, 149]. Onesagoras' dedications usually

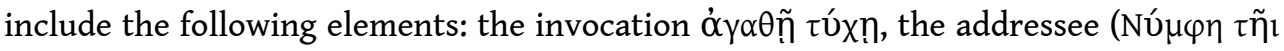

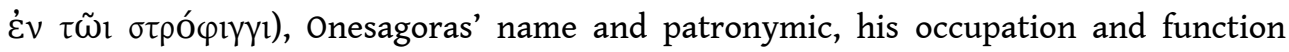




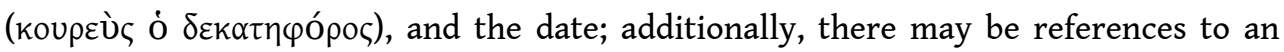

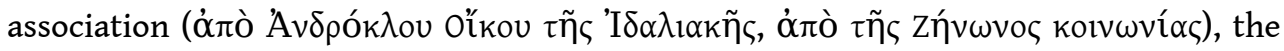

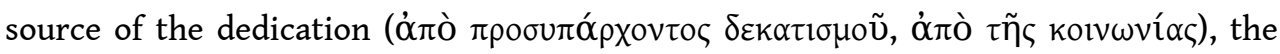
type of the dedicated vase, and the name of the potter. It seems that Onesagoras was member of an association dedicated to the worship of the Nymphs. The association met occasionally for drinking parties and sacrifices. The texts allude to various economic activities, such as the making of pottery and the production and trade of flax and linseed. As regards the designation $\delta \varepsilon \kappa \alpha \tau \eta \varphi$ ó $\rho$, , J. favors a religious meaning over a secular (tax-farmer), and wonders whether Onesagoras 'might have been responsible for collecting tithes on the agricultural produce payable by the association(s) to the Nymphs'. Onesagoras' close relation to the Nymphs resembles nympholepsy.

82) C.P. JONES, "Zeus Anabatênos and Zeus Kersoullos", ZPE 180 (2012), p. 233-236: J. presents an improved edition of a dedication to Zeus Kersoullos from the territory of Hadrianoi (modern Derecik, probably ancient Anabata, late 2nd/early 3rd cent.; see supra $\mathrm{n}^{\circ} 4$ ) [SEG LIX 1418]. The dedicant is Zeus Anabatenos, who set up a statue for Zeus

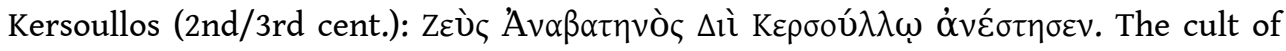
Zeus Anabatenos, whose epithet probably derives from Anabata (modern Derecik?) was already known (I.Hadrianoi 9). The cult of Zeus Kersoullos was also known through dedications from the territory of Hadrianoi (I.Hadrianoi 2-8) and Aizanoi (SEG LVI 1436:

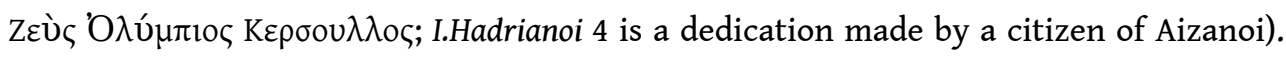
J. provides parallels for gods making dedications to other gods, i.e. dedications funded with sacred money (e.g. I.Thespiai 259). The two epithets (Anabatenos and Kersoullos) refer to two hypostases of Zeus that are so distinct that one Zeus can make a dedication to the other; similarly, Apollo of Klaros recommended a dedication to Apollo Soter in Kaisareia Troketta (IGR IV 1498). J. also republishes a dedication to Zeus Anabatenos (infra $\mathrm{n}^{\circ} 4$ ) inscribed on an altar. The text, engraved among images of a bull's head, an altar, a phiale and an unclear object ('a bust with hair extending sideways and coming to a point, and below the bust an object resembling a heavy pendant (perhaps a

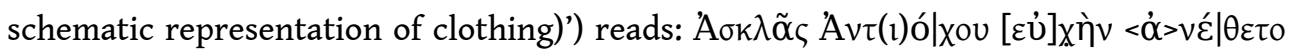

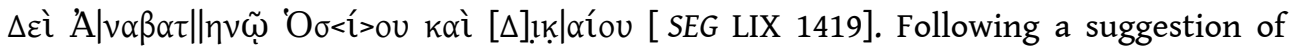
G. Petzl, J. argues that Asklas dedicated an altar of Hosios and Dikaios; the word $\beta \omega \mu$ óv is substituted by the representation of the altar. [I wonder whether the 'bust with hair' really is a bust. The three other objects are directly related to the use of the altar for offerings (altar, bull's head, phiale for libations); but I have no better explanation. Hosios and Dikaios were probably regarded as 'angels' of Zeus].

83) D.R. JORDAN, R.D. KOTANSKY, "Ritual Hexameters in the Getty Museum. Preliminary Edition”, ZPE 178 (2011), p.54-62: J.-K. present the preliminary edition of a very important lead tablet inscribed on both sides with hexametrical incantations that aim at protecting a house or a city from various dangers. The tablet, originally foldable to form a small portable packet, is of unknown provenance (probably Selinous, late 5th cent.); it was acquired in 1981 by the Getty Museum. [This text, known from preliminary reports, has already been discussed by many scholars, whose observations will be summarized in future issues of the EBGR. A recent collection of articles (C.A. faraone, D. obbink [eds.], The Getty Hexameters. Poetry, Magic, and Mystery in Ancient Selinous, Oxford, 2013), presents a very good overview of the significance of this document and the problems connected with its interpretation. In the following summary, I quote the text of the improved (but not yet final) edition presented in this 
collective volume and the translation of Faraone and Obbink]. The incantation in col. I of side A promises to protect the owner of the tablet ('whoever hides in a house of stone the notable letters of the sacred verses inscribed on tin'; ö

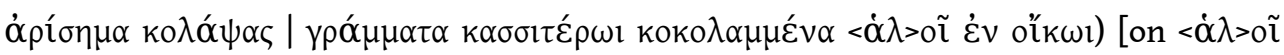

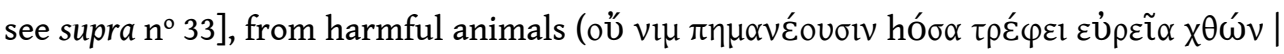

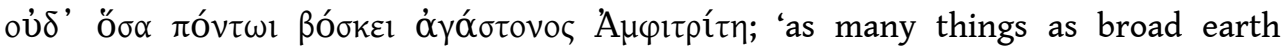
nourishes shall not harm him nor as many things as much-groaning Amphitrite rears in the sea'). The text then invokes Paieon ('Paean, for in every direction you send averting

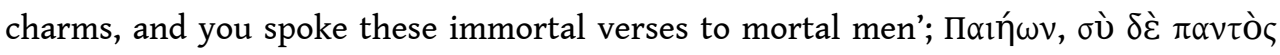

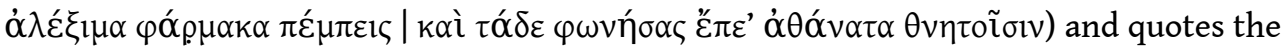
god's words: 'As down the shady mountains in a dark-and-glittering land a child leads out of Persephone's garden by necessity for milking that four-footed holy attendant of Demeter, a she-goat with an untiring stream of rich milk laden; and she follows, trusting in the bright goddesses with their lamps. And she leads Hecate of the Roadside,

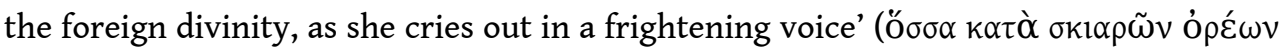

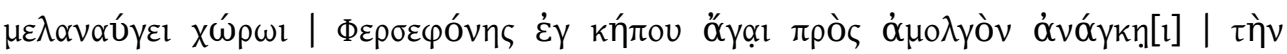

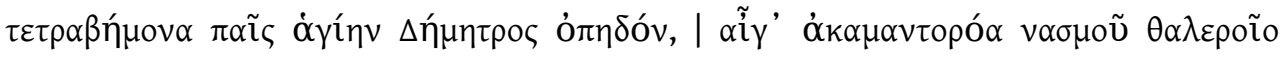

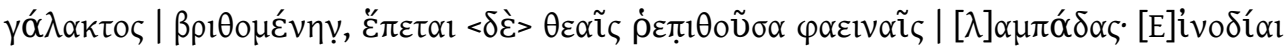

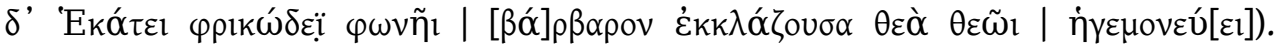
[Various contributions in C.A. FARAONE, D. OBBINK (eds.), The Getty Hexameters, recognize these verses as the original hexametrical version of what later became the incantation

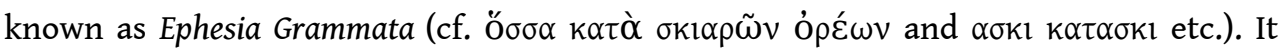
seems that the Ephesia Grammata developed from originally comprehensible dactylic

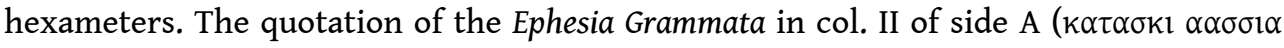
$\alpha \sigma \alpha \alpha$; see infra) reveals a process of devolution. I note that the 'textual confusion and creative phonetic play' (C.A. FARAONE, D. OBBINK, "Introduction", in op.cit., p. 3) that one observes in this incantation, can also be observed in the Dionysiac-Orphic tablets. In

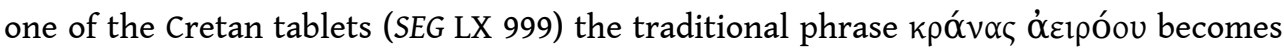

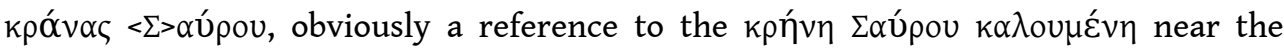
Idaean Cave, mentioned by Theophrastos, Historia plantorum III, 3, 4.] The words of Hekate, in the remaining part of col. I, which appears to be a sort of historiola, are not well preserved. The incantation in col. II of side A again invokes Paieon, but the text is very fragmentary: 'Paian, for you yourself send averting charms, give ear in your mind

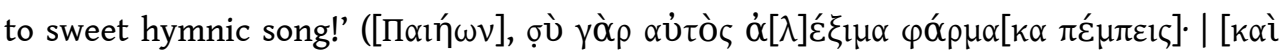

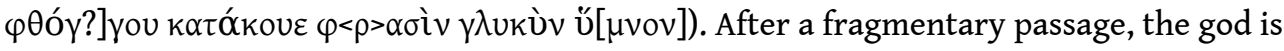
invoked, again ('Paian, for you in every direction are cure-bringing and excellent';

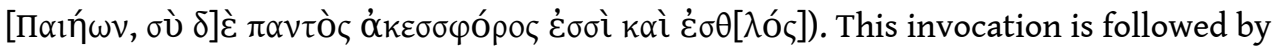

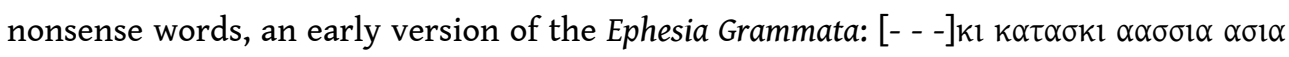
$\varepsilon v \delta \alpha \sigma[[--]$. The remaining verses and the verses on side B (with references to the son of

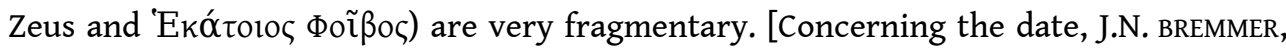
"The Getty Hexameters: Date, Author, and Place of Composition", in C.A. FARAONE, D. OBBINK (eds.), The Getty Hexameters, p. 21-29, has rightly observed a strong similarity in vocabulary between the tablet and Euripides. Since the text on col. I uses the rare word $\mu \varepsilon \lambda \alpha v \alpha u \gamma \eta$ ', which also appears in Euripides, Hecuba, 152, Bremmer assumes that the incantation's author knew and quoted Euripides. For this reason, he suggests dating the text to shortly before the destruction of Selinous in 409 BCE. This argument is not conclusive. Firstly, the text on the tablet may copy a text that is much older than the 
tablet; as a matter of fact, there are good reasons to assume that the incantations were orally composed, transmitted, and performed for a long time, before they were written down. In that case, a comparison with Euripides can only provide clues for the date of the prototype, not of the copy that we have on the tablet. Secondly, and most importantly, Euripides was both interested in and informed about contemporary religious trends and ritual texts. There is no proof whatsoever that the word $\mu \varepsilon \lambda \alpha v \alpha u \gamma \eta$ ' is his creation. In Hecuba he may well have adopted a word from a ritual text, i.e. the text in which the incantation on the tablet ultimately originates. So, Euripides' Hecuba may be the terminus ante, not post quem for the composition of the text on the tablet].

84) M. JOST, "La vie religieuse à Lykosoura", Ktema 33 (2008), p. 93-110 [BE 2009, 241; SEG LVIII 403]: J. discusses the content of a cult regulation from Lykosoura concerning the cult of Despoina (IG V 2, 514; IPArk 607; EBGR 1999, 254, 3rd cent.). This text lists objects that were not allowed to be brought into the sanctuary of Despoina. J. explains the prohibition of gold objects as the result of 'un désir de dénuement rituel, lié à l'idée de pureté' (95) [a connection with ideas of purity is unlikely; valuable objects distracted the attention of worshippers, presented a clear danger of theft, and provoked envy]. Simplicity and purity also explain prohibitions against certain types of dress; some objects were connected with superstitions and magical practices. With regard to

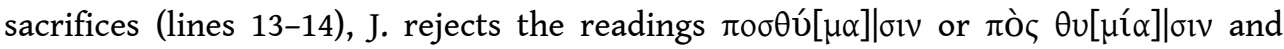
prefers to read đòৎ $\theta u ́[\omega] \mid \sigma i v$ (for the sacrificial offerings) [but as A. Matthaiou points out in SEG LVIII 403, all these restorations are based on unattested words]. Aүó́ $\lambda \mu \alpha \tau \alpha$ appear among the items that were used for sacrificial offerings; J. doubts that they should be interpreted as small clay figurines and leaves the question of the word's meaning in this context open. J. also discusses the possible nature of the mysteries of Lykosoura.

85) D. КАн, "Eine neue Brunneninschrift aus Priene", EA 45 (2012), p. 55-70 [BE 2013, 363]: Ed. pr. of a fragmentary inscription that regulates the use of a fountain (Priene, 3rd cent.). The text forbids the use of the fountain for ritual purifications ( $\mu \eta \delta \grave{\varepsilon}$

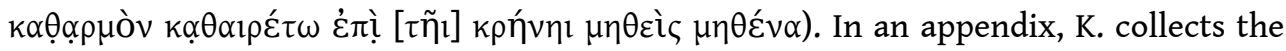
cult regulations that prescribe ritual cleanings before entering a sanctuary.

86) M. KAJAVA, “'Hera non permette che...' Ancora sul dischetto bronzeo di Cuma”, in L. CHIOFFI (ed.), Il Mediterraneo e la storia. Epigrafia e archeologia in Campania: letture storiche. Istituto Italiano per gli Studi Filosofici, Napoli, 4-5 dicembre 2008, Naples, 2010, p. 7-22 [SEG LX 1026]: An inscription on a bronze disk from Kyme/Cumae (7th/6th cent.; IGDGG I 14) has been interpreted as an oracular response, with which Hera restricted the

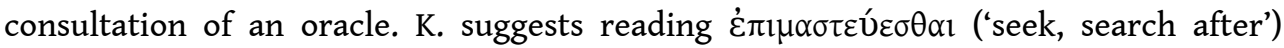

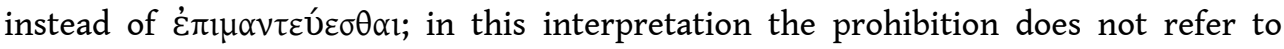
divination but to the behavior of the worshippers in Hera's sanctuary; consequently, there is no evidence that the oracle of Kyme originally belonged to Hera.

87) M. KAJAVA, "Honorific and Other Dedications to Emperors in the Greek East", in More than Men, Less than Gods, p. 553-592: In this important contribution to the study of the imperial cult $\mathrm{K}$. studies the vocabulary used in inscriptions recording the dedication of statues and altars to emperors or members of the imperial family. Admitting that clear distinctions are sometimes difficult, he distinguishes various types of dedicatory inscriptions using as criteria the type of dedication (honorific or sacral), the dedicated object (statue, altar, other object), the presence of additional recipients, and the case in 
which the name of the emperor or the member of the imperial family is given (accusative, dative, genitive): A1) the name is in the accusative, i.e. the dedication refers to the erection of a statue (e.g. IG VII 63; I.Ephesos 265); A2) the name is in the accusative, but the emperor/member of the imperial family is associated with a god (e.g. IG II ${ }^{2}$ 3250: Caius Caesar and Ares); B1) the dedication of a statue is addressed to the emperor/member of the imperial family alone; the name is in the dative (e.g. IG VII 3418; SEG LVII 1650); B2/3) dedications of altars; the name is in the dative; the dedicant is named (e.g. SEG XXVII 229) or omitted (e.g. IG V 1, 373); B4) dedications of statues with the name of the recipient in the dative; the recipient is associated with a god (e.g., I.Pergamon 365); B5) sacral dedications with the name of the recipient in the dative (IG XII 2, 184); B6-9) joint dedications of altars (IGLS III 715; SEG XXV 680) or other objects (IGR IV 239) to emperors and gods, sometimes with additional recipients (the polis, the demos, etc.; e.g. TAM V 2, 903: altar; IG XII 6, 571: other object); the names of the recipients are in the dative; B10) sacral dedications to the Theoi Sebastoi (in the dative), with or without other divine recipients (e.g. I.Selge 1; MAMA VIII 448); C1) erection of altars; the name of the emperor is in the genitive; further gods may be named (e.g. IG II $^{2}$ 3224/3225; IG XII 6, 499; SEG XLII 477); C2) erection of a statue with the name of the emperor in the genitive (e.g. SEG LVII 1479; I.Rhod.Peraia 256); D) erection of statues; the name of the emperor is in the nominative (e.g. I.Pergamon 357); E) dedications on behalf/for the well-being ( $\left.\dot{0} \pi \varepsilon \dot{\rho} \sigma \omega \tau \eta i^{\prime} \alpha \varsigma\right)$ of the emperor (e.g. IG II ${ }^{2} 3181$ ). This study shows that the context of an inscription must be studied carefully. There are some peculiar cases, such as the dedication of the statue of an emperor to a god (M. HOLLEAUX,

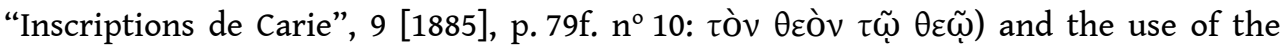
accusative for the dedication of a cult statue (AvPergamon VIII 3,6). The inclusion of further recipients (the polis, the demos, villages, etc.; e.g. IGR IV 1492, 2234) make the dedicated object, often a building, the joint property of the recipients [and thus protect it from abuse].

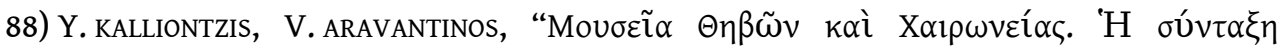

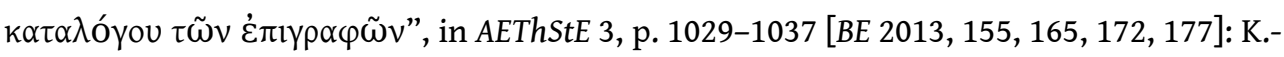
A. report on work conducted in the Museums of Thebes and Chaironeia towards the compilation of epigraphic catalogues. They present the ed.pr. of a dedication to Zeus Homoloios (Hyettos, 2nd cent.) and republish a dedication of an honorific statue to the gods (Thebes, 1st. cent.).

89) M. KANTIRÉA, "Étude comparative de l'introduction du culte impérial à Pergame, à Athènes et à Éphèse", in More than Men, Less than Gods, p. 521-551: A comparative study of the introduction of the imperial cult in Pergamon, Athens, and Ephesos shows significant differences, determined by local traditions and historical contexts. In Pergamon, Attalid traditions of ruler cult played an important part; Athens highlighted the commemoration of the Persian Wars and the association of Augustus with Apollo; in Ephesos the Roman elite contributed to the introduction of the cult.

90) K. KARILA-COHEN, "La Pythaïde et la socialisation des élites athéniennes aux II $^{\mathrm{e}}$ et $\mathrm{I}^{\mathrm{er}}$ siècles avant notre ère", in Individus, groupes et politique, p. 365-383: A prosopographical study of the participants in the Pythais shows that they belonged to the Athenian elite; the participation in this ritual gave an opportunity for social contacts among these families and created a sense of identity.

91) B. KAYACHEV, "The So-Called Orphic Gold Tablets in Ancient Poetry and Poetics", ZPE 180 (2012), p. 17-37: The author detects allusions to the journey of the soul to the 
underworld, as described in the texts of the Dionysiac-Orphic tablets, in Greek and Latin poetry, especially in Theocritus' poem Dioskouroi, Callimachus' Hymn to Athena, Apollonius' Argonautica (III, 200-202, 222-227, IV, 1381-1501), Vergil, Aeneid VI, and possibly Philitas' Demeter. Such allusions do not necessarily imply that these authors had personal knowledge of the tablets. They may have been familiar with the poem, passages of which are quoted in the tablets.

92) D. KNOEPFLER, “Les agonothètes de la Confédération d'Athéna Ilias. Une interprétation nouvelle des données épigraphiques et ses conséquences pour la chronologie des émissions monétaires du Koinon", Studi Ellenistici 24 (2010), p. 33-62 [BE 2011, 501; SEG LX 1314]: A decree honoring an agonothetes of the Great Panathenaia celebrated for Athena Ilias (SEG LIII 1373; EBGR 2003, 121) is K.'s starting point for an attempt to reconstruct the organization of the federation of cities that participated in the cult of Athena Ilias

(cf. I.Ilion 2, 5, 10, 12; I.Alexandreia Troas 50; SEG LIII 1373 = LVII 1215). Each city-member sent two delegates to the synhedrion, regardless of its size, possibly following the model of the Delphic amphiktyony. Additionally, a board of five agonothetai was responsible for the organization of the agonistic festival. The federation may have been divided into five districts ('conscriptions'), each of which was represented by an agonothetes. To explain the number of the agonothetai, $\mathrm{K}$. assumes that there was a cycle of four years, within which there were four annual celebrations of the Panathenaia and one

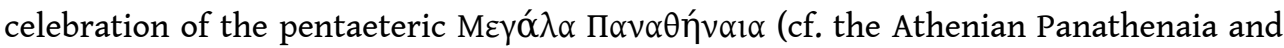
Great Panathenaia).

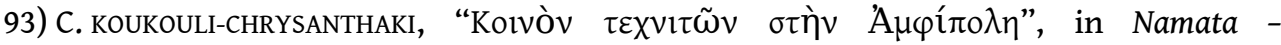
Pandermalis, p. 235-247 [BE 2013, 278; SEG LXI 485]: Ed. pr. of an honorific inscription for priests of Athena by an association of technitai (Amphipolis, 84/83 BCE). Under the heading

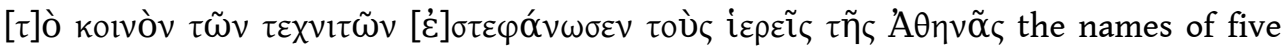

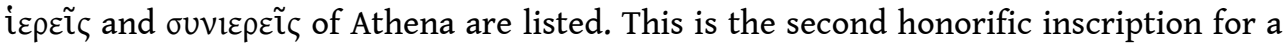
board of priests of Athena by the same koinon (SEG LXVIII 716 ter, 89/88 BCE). The nature of the kolvòv $\tau \tilde{\omega} v \tau \varepsilon \chi v ı \tau \tilde{\omega} v$ is not clear. They may have been artisans under the patronage of Athena Ergane, since one of the priests, M. Caecilius Sotas, may be identified with a $\chi \alpha \lambda_{\kappa \varepsilon u ́} \varsigma$ known from a now lost inscription. However, the editor does not exclude the possibility of a Dionysiac association of theater artists.

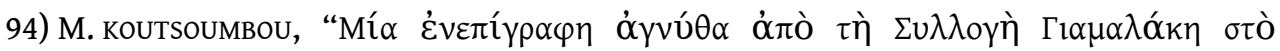

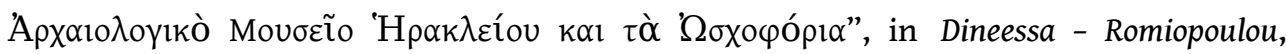
p. 579-585 [BE 2013, 66]: Ed. pr. of an inscribed loom-weight in the private collection of S. Giamalakis in Crete (unknown provenance, ca. 3rd cent.). The inscription, engraved after firing, consists of the ritual cry $\dot{\varepsilon} \lambda \eta \lambda \varepsilon v$, iove, iov́, which according to Plutarch (Theseus 22,4) was shouted during the libations at the Oschophoria in Athens. After detailed discussion of the literary, archaeological, and epigraphic evidence for the Oschophoria, K. proposes that this loom-weight was dedicatory, dedicated in the sanctuary of Athena Skiras [if it is not a modern forgery, as are many objects in the Giamalakis Collection; the letterforms look very suspicious].

95) V.V. KRAPIVINA, "Home Sanctuaries in the Northern Black Sea Littoral", in Ancient Sacral Monuments, p. 127-147 [BE 2011, 458; SEG LX 831]: K. discusses evidence for domestic sanctuaries in the North Shore of the Black Sea. She presents a statuette of Kybele found in the citadel of Olbia (135f.); according to an inscription on the base, it 
was dedicated to Meter Theon. K. interprets the room in which the statuette was discovered as a domestic shrine destroyed in the early 3rd cent. CE. [A. AVRAM, BE 2011, 458 and Pontica 44 (2011), p. 139, presents an improved text; he dates this statuette to the late 3rd cent.; two heads of Aphrodite and Hermes found in the same context date to the Hellenistic period].

96) V.V. KRAPIVINA, "New Data on the Significance of the Cult of Aphrodite in Olbia Pontica", in Ancient Sacral Monuments, p. 148-170 [BE 2011, 455; SEG LX 828]: K. discusses the cult of Aphrodite in Olbia and presents a selection of graffiti on vases dedicated to the goddess. The texts give the name of the goddess in the genitive or dative. A graffito possibly has the epithet ' $\mathrm{O} \lambda[\beta$ in $]$. A vase is designated as 'sacred', i.e., belonging to the

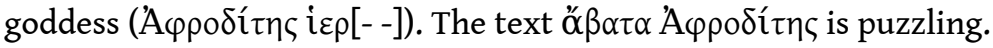

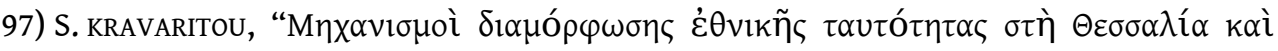

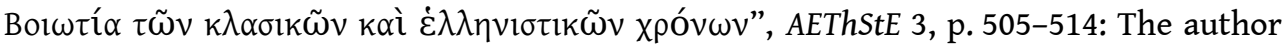
examines how religion and mythology contributed to the shaping of distinct 'ethnic' identities in Thessaly and Boiotia in the Classical and Hellenistic periods. Genealogical myths and cults (Athena Itonia in Koroneia, Athena Alalkomenia, and Poseidon in Onchestos) played an important part in Boiotian identity, establishing a connection between the Boiotian ethnos and its territory. The same can be observed in Thessaly in the case of the cult of Athena Itonia (cf. SEG LIII 849 and LV 605). She suggests that the importance of Athena Itonia for both Boiotians and Thessalians developed between the 8th and the 6th cent., when the two neighboring ethne developed their identities exploiting mythological traditions connected with Achaia Pthiotis (the origin of Protesilaos in Iton and the cult of Athena Itonia).

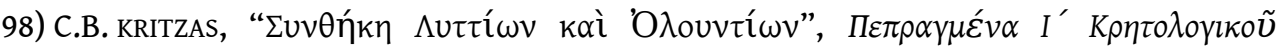

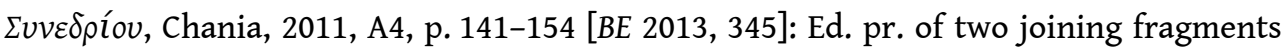
of an inscription from Chersonesos that preserves a copy of a treaty between the Cretan cities of Lyttos and Olous (Chaniotis, Verträge $n^{\circ} 60,111 / 10 \mathrm{BCE}$ ). The text mentions the festivals to which the citizens of the two cities were invited and preserves the text of the treaty oath. The other copies of this treaty were fragmentary (Athens: IG II ${ }^{2}$ 1135+add;; Rhodes: SEG XXXIII 638 and XXXVII 698). The new copy shows that the Olountians were invited to two commemorative anniversaries in Lyttos: the anniversary of the city's re-foundation after its destruction in a war in 221/20, and the anniversary of the destruction of Lyttos' traditional enemy, Dreros; the Lyttians were invited to the festival of Britomartis and to the Thiodaisia, a festival of Dionysos

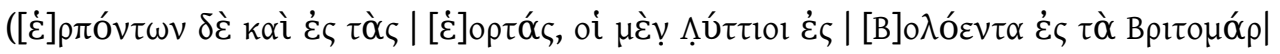

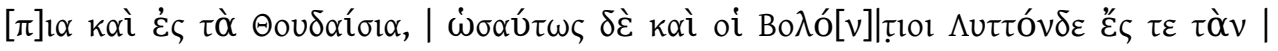

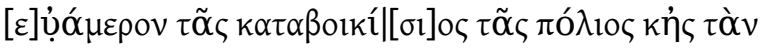

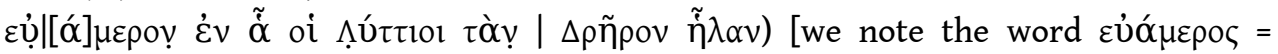

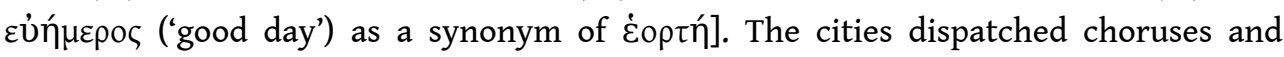

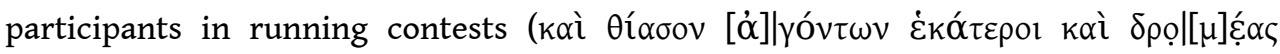

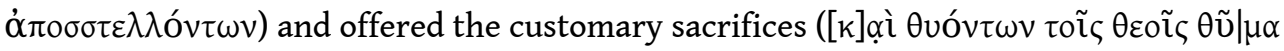

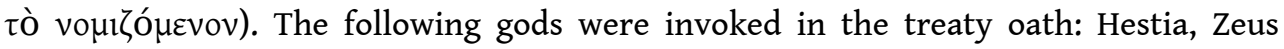
Kretagenes, Zeus Monnitios, Zeus Idaios, Zeus Tallaios, Hera, Poseidon, Athena, Apollo Pythios, Leto, Artemis, Ares, Aphrodite, Hermes, the Kouretes, the Nymphs, Britomartis

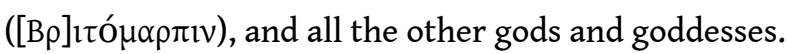

99) C.B. KRITZAS, “A Greek Inscription from Tarraco (CIL II ${ }^{2} / 14,2$ G16)”, ZPE 181 (2012), p. 88-90: K. corrects the reading of a painted inscription on a wall-fresco in the villa of 
C. Valerius Avitus in Tarraco [EBGR 2011, 3]: the inscription should be read as 'Ak $\theta \varepsilon 1 \alpha$,

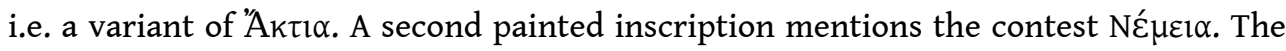
owner of the villa with the fresco had been a winner at the Aktia and Nemea.

100) G. LABARRE, M. özSAIT, N. özsAIT, "Les inscriptions de Yazili Kanyon", Anatolia Antiqua 17 (2009), p. 175-186: The authors republish the inscriptions from Yazili, near Çandir in Pisidia (area of ancient Anaboura). A well-known dossier of rock-cut inscriptions from a sanctuary of Apollo (SGO IV 18/09/01-03, 2nd cent. CE) consists of a dedicatory epigram to Apollo Phoibos, protector of the travelers (3), a dedication to Apollo (2), and a philosophical poem (1). The poem summarizes Stoic views on freedom, attributed to

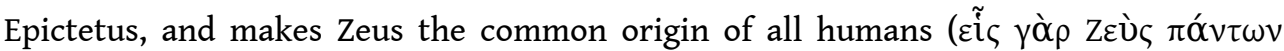

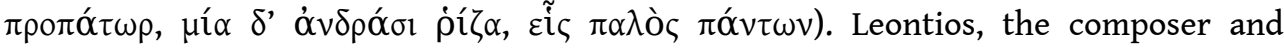
dedicant of the poem, may be identified with a homonymous poet known from an inscription in Adada (GVI 1397).

101) G. LABARRE, M. özSAIT, N. özSAIT, "Monuments funéraires et inscriptions de Pisidie (Burdur-Isparta)", Anatolia Antiqua 18 (2010), p. 59-89 [BE 2011, 579; SEG LX 1480, 1497]: Ed. pr. of an inscription that records the construction and dedication of a temple of Zeus Heliopolites at Sazak (ancient Takina?, Pisidia, ca. 200 CE; p. 74-77) [SEG LX 1497]. The names of the members of a $\varphi \rho \alpha$ c $\rho \rho \alpha(15 \mathrm{men})$ are listed under the heading

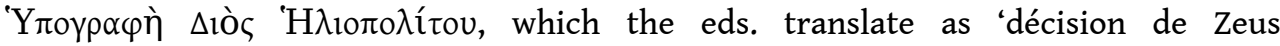
Héliopolitès'. This phratra, a religious association, dedicated the temple for the

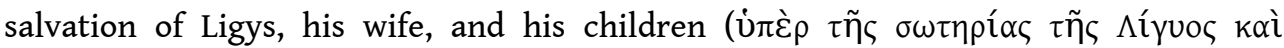

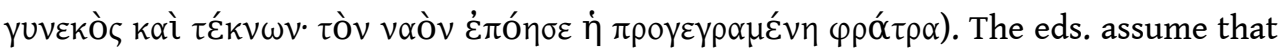
Ligys was a prominent member of this association. The cult of Zeus Heliopolites was previously attested in Pisidia (SEG XXXI 1233). [P. HAMON, BE (2011) no 579, rightly points out that the translation 'décision de Zeus Héliopolitès' does not make any sense. T. CORSTEN, Gephyra 8 (2011), p. 135-140, presents an improved text and commentary. He

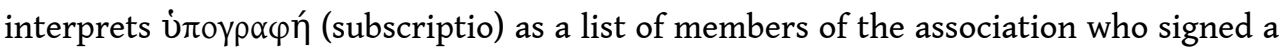
document for this project. Two of the members are designated as $\Lambda$ í not 'fils de Ligus, intendant' but 'steward of Ligys'. The dedicants must have been slaves and stewards of Ligys, an estate owner in that region]. The authors also republish a dedication to Mes (p. 83-85 $\mathrm{n}^{\circ}$ 2) [for an improved text see supra $\mathrm{n}^{\circ}$ 79] and a dedication to Zeus Galaktenos ( $\Delta \grave{\imath ̀} \Gamma \alpha \lambda \alpha \kappa \kappa \tau \eta v \tilde{\omega})$ from Konana (p. $85 \mathrm{n}^{\circ}$ 3, Imperial period) [SEG LX 1480 ], whom they regard as protector of the animals that produce milk [but see infra $\mathrm{n}^{\circ}$ 79]. A third dedication from the same place (p. 85-87 $\mathrm{n}^{\circ} 4$, early $3 \mathrm{rd}$ cent. CE) records

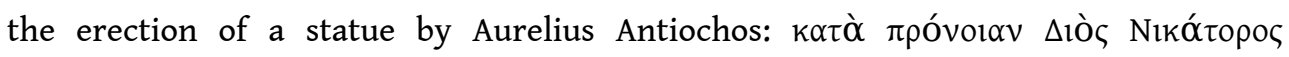

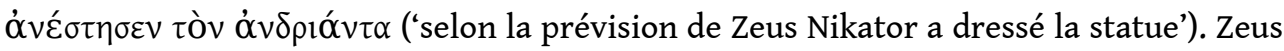
Nikator is attested in Tymandos (MAMA IV 226) and Arykanda (SEG XLVI 1704) [there is also an attestation in Side: G.E. BEAN, Side Kitabeleri. Inscriptions of Side, Ankara, 1965, $\mathrm{n}^{\circ}$ 100]. The eds. wonder whether this is the cult of Seleukos Nikator, referring to the priest of Zeus Seleukos Nikator in Seleukeia of Pieria (e.g. IGLS XXXV III 2, 1184). In Doura Europos a priest of Seleukos Nikator still existed in $180 \mathrm{CE}$. Therefore, the cult of the founder of the Seleucid dynasty may have continued in Asia Minor under the name Zeus Nikator after the end of the Seleucid rule. The dedicant did not erect the statue of

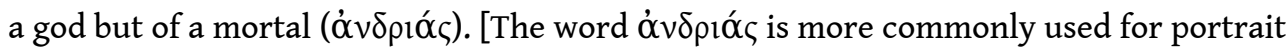

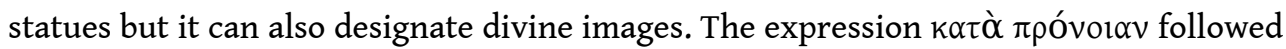
by the name of a god is unattested; but it must refer to an expression of divine will and,

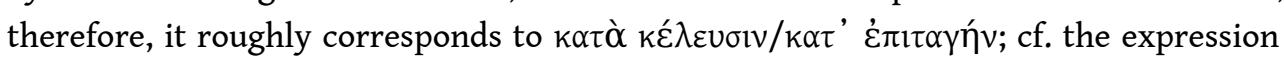




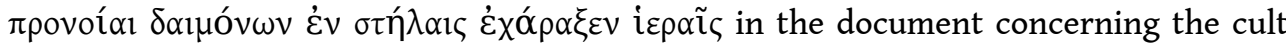
reforms of Antiochos of Kommagene (e.g. IGLS I 52 lines 8f.) and $\theta \varepsilon o \tilde{v} \pi \rho o v o i ́ \alpha$

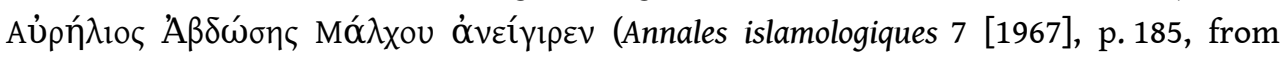
Syria; cf. IGBulg III 1133). As for Zeus Nikator it is quite possible that the epithet originated in a joint cult of Seleukos Nikator and Zeus. Although the cult of Hellenistic rulers sometimes continued well into the Imperial period, as A.S. Chankowski has shown ("Les cultes des souverains hellénistiques après la disparition des dynasties: formes de survie et d'extinction d'une institution dans un contexte civique", in Des rois au Prince, p. 271-290), in this case it is quite certain that Nikator is conceived just as an

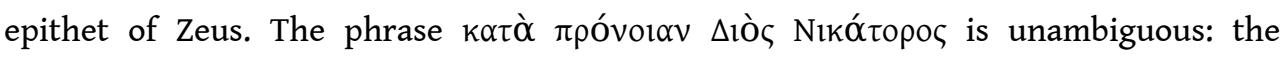
command for the dedication was given by the god, and there is no evidence for a divinised Hellenistic king requesting a dedication through dream, oracle, or another such medium.]

102) G. LABARRE, M. öZSAIT, N. ÖzSAIT, I. GÜCEREN, "La collection du Musée d'Uluborlu: nouvelles inscriptions d'Apollonia Mordiaon", Anatolia Antiqua 20 (2012), p. 121-146 [BE 2013, 420]: Ed. pr. of 28 inscriptions from Apollonia Mordiaon, now in the Museum of Uluborlu. The most interesting texts are two decrees on a stele. They are very fragmentary; the eds. recognize in the first text an honorific decree for a woman. [To judge from the ph., one can read more on the stone than the eds. have read; P. HAMON, $B E$ 2013, 261, suggests several plausible readings and restorations. The honorand,

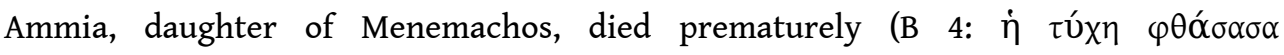

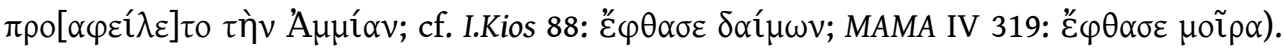

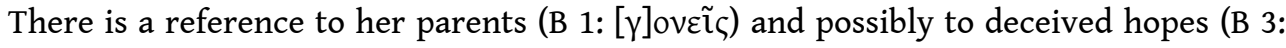
$[\tau \grave{\alpha} ?] \varsigma[\dot{\varepsilon}] \lambda \pi\{[\delta \alpha \varsigma])$. With this decree the city offers consolation to her family (B 8:

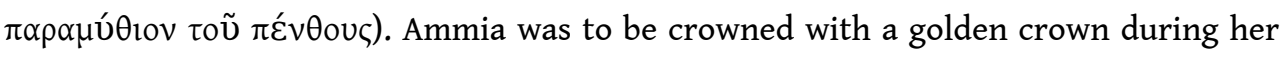

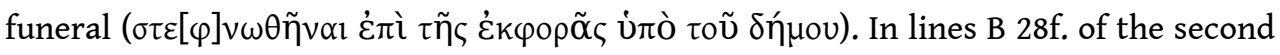

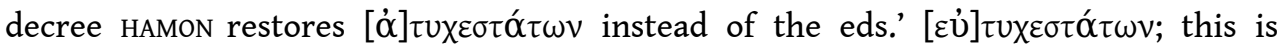

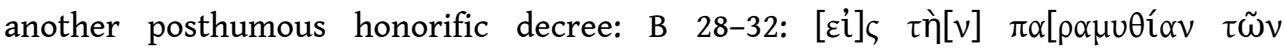

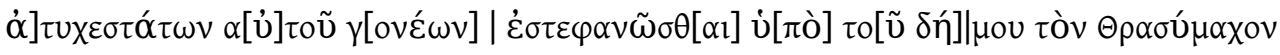

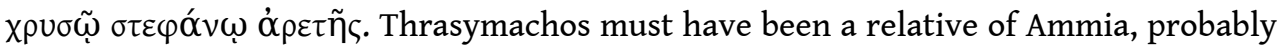

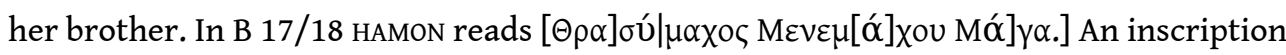

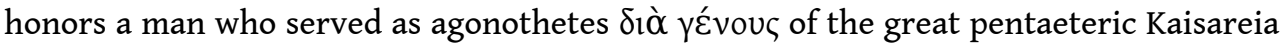
$(3,1$ st/2nd cent.). A fragmentary inscription on an epistyle refers to honors granted to

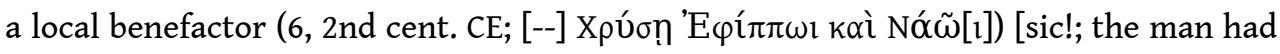

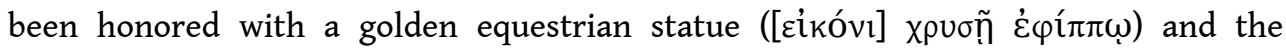
erection of his temple (?). The latter implies the introduction of his cult. This would be a very unusual honor in the imperial period, and the erection of a golden equestrian statue is similarly extraordinary, attested e.g. for Attalos III (I.Pergamon 246) and Iollas in Sardeis (1st cent., Sardis VII 1, 27). Another late Hellenistic example from Kelainai/ Apameia, an honorific inscription for a gymnasiarchos, was published recently: T. DREWBEAR, J.-M. FILLON, "Honneurs pour un gymnasiarque à Apamée", in L. SUMMERER, A. IVANTCHIK, A. von KIENLIN (eds.), Kelenai - Apameia Kibotos. Développement urbain dans le contexte anatolien, Bordeaux, 2011, p. 277-280. To judge from the letterforms, the inscription does not date to the 2nd cent. CE but to the 2nd cent. BC (at the latest). Apollonia established the cult of a local Hellenistic statesman (cf. $[\varphi \imath \lambda]$ ó $\pi \alpha \tau \rho v$ ), who must have saved his city (cf. $\sigma \omega \tau \tilde{\eta} \rho \alpha)$ during a war.] An inscription (8, 1st/2nd cent.)

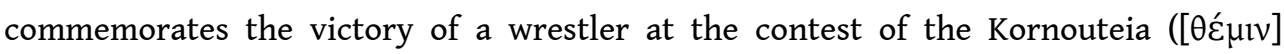




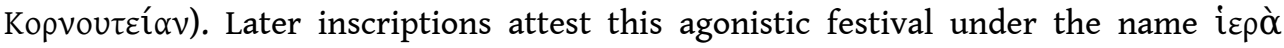

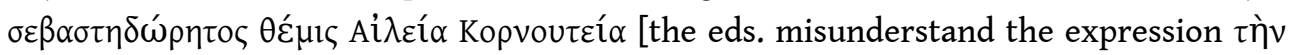

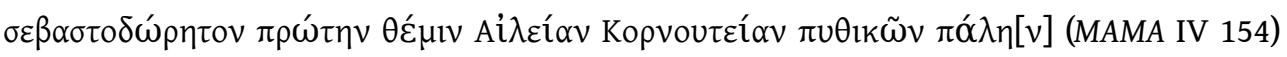
and think that this contest was an isopythian agon ('équivalent aux concours pythiques'); but pythikoi refers to an age-class and has nothing to do with the status of the Kornouteia]. We also note an altar of Zeus $(9,2 \mathrm{nd} / 3 \mathrm{rd}$ cent.) and the re-publication of an inscription recording the dedication of a statue of Apollo Soter by his priest $(10=$ $B C H 17$ [1893], p. $258 \mathrm{n}^{\circ}$ 38, Imperial period).

103) A. LAJTAR, J.J. MARTINOVIć, "Greek Inscriptions in the Bay of Kotor (Boka Kotorska), Montenegro: 'Pierres errantes' and Objects of Local Provenience”, Palamedes 7 (2012), p. 81-107: New critical edition of two Hellenistic dedications by peripoloi (guards) and their officer from the territory of Rhizon in Dalmatia. The first text was a dedication to Medauros, the patron god of Rhizon; the addressee of the second dedication is unknown.

104) S.D. LAMBERT, "A Polis and its Priests: Athenian Priesthoods before and after Pericles' Citizenship Law”, Historia 59 (2010), p. 143-175: L. argues that no priesthood of the polis of Athens created after the citizenship law of Pericles was allocated to a genos; by contrast, all polis priests created before that law were appointed by gene. Priesthoods following the new model, with priests selected by lot from among all Athenians, include those of Athena Nike, Asklepios, and possibly Bendis. Priesthoods in new polis cults of foreign gods were appointed from groups of orgeones. Priesthoods in Attic extra-urban cults may have been appointed from the demes.

105) S.D. LAMBERT, Inscriptiones Graecae. Voluminis II et III editio tertia. Inscriptiones Atticae Euclidis anno posteriores. Pars I. Leges et decreta. Fasciculus II. Leges et decreta annorum 352/1322/1, Berlin, 2012: This fascicule of the third edition of IG II assembles the laws and decrees of the period from 352 to 322 BCE, i.e., an very important period for the reorganization of Athenian cults and the administration of sanctuaries. The inscriptions are presented very often with new readings and restorations. This volume should be used together with S.D. LAMBERT, Inscribed Athenian Laws and Decrees 352/1-322/1 BC: Epigraphical Essays, Leiden, 2012, which contains detailed discussions both of documents and of general phenomena (see esp. p. 48-91, 'Religious Regulations'). Cult regulations et sim.: The volume contains several texts included in LSCG: the decrees pertain to the hiera orgas and its borders ( $292=$ LSCG 32); the foundation of a sanctuary of Aphrodite by the Kitians (337 = LSCG 34); the restoration of the statue of Athena Nike (444 = LSCG 35); the Small Panathenaia (447 = LSCG 33); the organization of a festival (the Dipoleia?; 551 $=$ LSCG 179). The dossier of laws proposed by Lykourgos in $335 \mathrm{BCE}$ concerning financial matters of various cults (445) has not been included in the Lois sacrées. The laws in this fragmentary inscription deal with dedications, the funding and preparation of processions, and the acquisition of ornaments (кó $\sigma \mu \circ)$ ) for the worship of Zeus Soter and Athena Soteira, Zeus Olympios, Dionysos, Athena Itonia, Agathe Tyche, Artemis Mounychia, the Twelve Gods, Amphiaraos, Asklepios, Artemis Brauronia, Demeter and Kore, and other deities. Another cult regulations that had not been included in the LSCG is a small fragment concerning a sanctuary (and possibly the leasing of sacred land; 487). Two small fragments deal with an agonistic festival and a panegyris (448) and an agonistic festival, a banquet, and a sacrifice to Athena (449) respectively. See also below on 448-449. Sanctuaries and sacred land: A supervisor of fountains was honored for his services concerning fountains in the sanctuaries of Ammon and Amphiaraos (338). 
Phanodemos was honored for his services to the sanctuary of Amphiaraos (348), for proposing laws concerning the celebration of the penteteris in the most beautiful

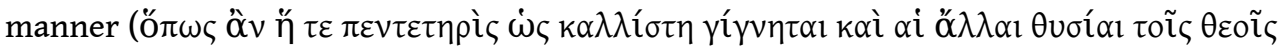

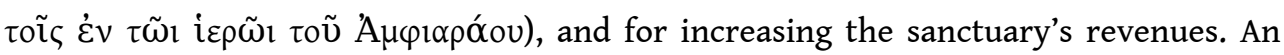
unusual decree, proposed by Phanodemos, provides for the offering of a golden crown to Amphiaraos (349), 'because the god takes good care of the Athenians and the others who arrive to the sanctuary' [see EBGR 2010, 171]. Festivals and cults: Officials are honored for the services they provided in festivals and cults: the supervisors of the agon and the festival of Amphiaraos (355), the priest of Asklepios (359), the priest of Dionysos, Poseidon Pelagios, Zeus Soter, and Ammon, and the hieropoioi (416), the hieropoioi (369), the architheoros to the Nemea (375), a man who offered his services to the choregoi of the Dionysia (473; see also supra on Phanodemos). Festivals are occasionally mentioned in the context of the announcement of honors: Dionysia (378), Panathenaia (298), Thargelia (370). A small fragment refers to the travel expenses of the Pythaistai (533). Dedications: A decree proposed by Phanodemos provides for a dedication to Hephaistos and Athena Hephastia (306 II). A dedication was made to Amphiaraos through subscription (360). Oaths: The treaty oath of the treaty with Philip II $(318,338 / 7$ BCE) invokes Zeus, Ge, Helios, Poseidon, Athena, Ares, and all the gods. Cf. the oaths of treaties with Eretria (412) and with an anonymous city (488).

106) I. LAZARenko, E. MincheVA, R. EncheVA, N. Sharankov, "The Temple of the Pontic Mother of Gods in Dionysopolis", in Ancient Sacral Monuments, p. 13-62 [BE 2011, 448; SEG LXI 758-779]: The authors summarize the results of research conducted in the temple

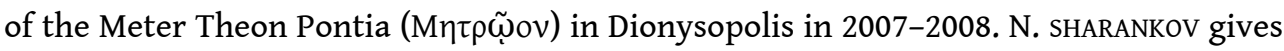

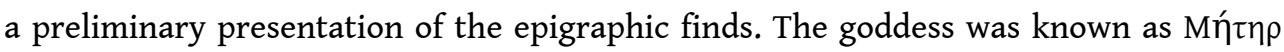

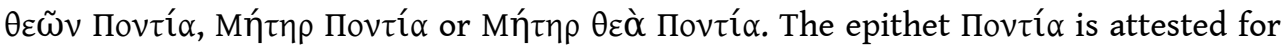
the Mother of the Gods for the first time but is well-known for other gods and

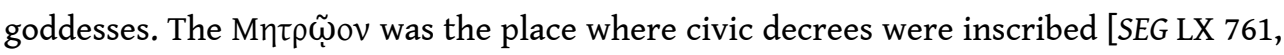

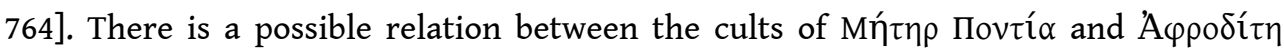

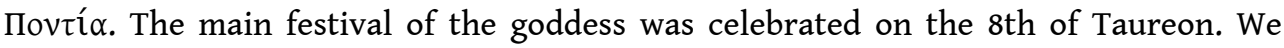
mention the epigraphic finds with religious significance: 1) A decree honors several persons, who were 'asked by the Dionysopolitans to propitiate the gods of the city

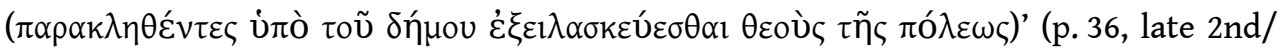
early 1st cent.) [SEG LX 760]. 2) A decree honors the benefactor Polyxenos of Mesambria (p.35f., late 2nd/early 1st cent.), who was a hieronikes [SEG LIX 730; LX 762]. 3) A document concerns an endowment given by Diodoros for the $\pi \alpha v \eta ́ \gamma v \rho i \varsigma$ of Meter Theon

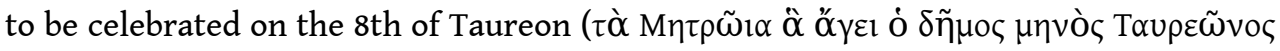

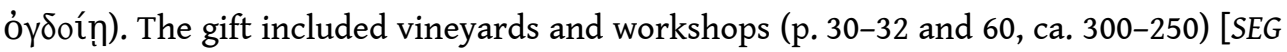
LX 765]. 4-5) A base is inscribed with a list of priests of Dionysos (p. 30 and 34, 3rd cent.); in one year, the god served as priest (line 6: [ $\triangle \mathrm{ló}] v v \sigma o \zeta)$ [SEG LX 766]. This base was re-used later as the base of a statue of Meter Theon, designated as the pure

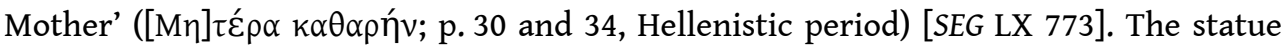
was dedicated to Meter Theon Pontia by Apollonios [according to A. Avram, apud SEG LX 773, possibly to be identified with a man who served as priest of Dionysos (IGBulg I ${ }^{2}$

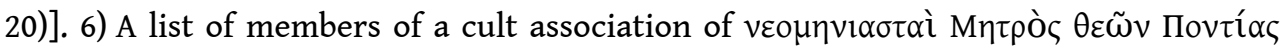
(p. 32f., after 212 CE) [SEG LX 767] is inscribed on a relief stele. The pediment depicts four men surrounding the goddess. The association was presided over by a chairman,

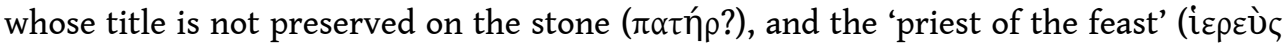




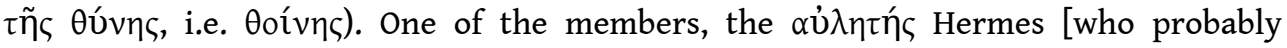
performed at the banquets], appears in the same function also in an association of

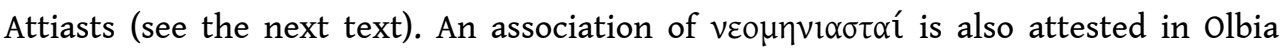

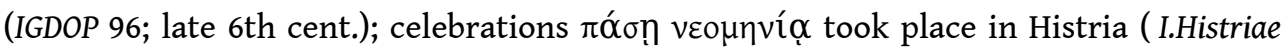
57; 2nd cent. CE). 7) A stele decorated with a relief depicting Attis with shepherd's crook and syrinx is inscribed with a list of the members of a cult association of

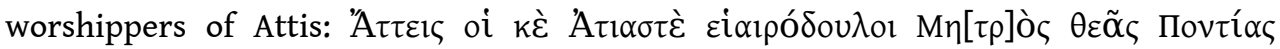
(p. 33f., after $212 \mathrm{CE}$ ). M. Aurelius Koures, who is named first, served as priest of Meter

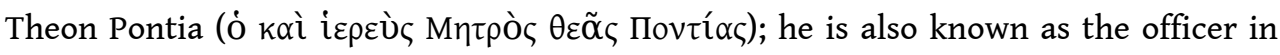

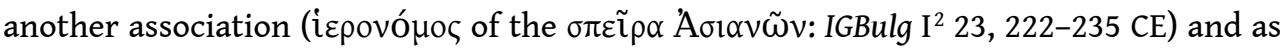

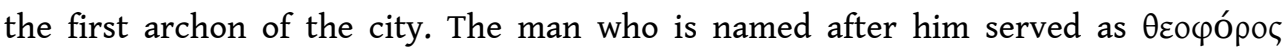

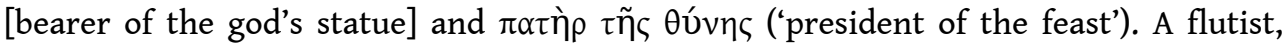

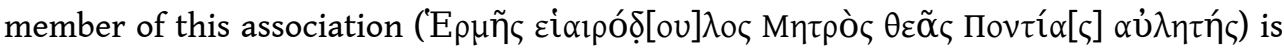

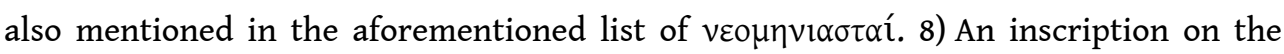
pediment of the temple reports that the temple was dedicated by Demophon, priest for

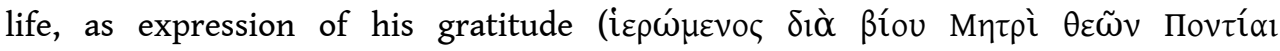

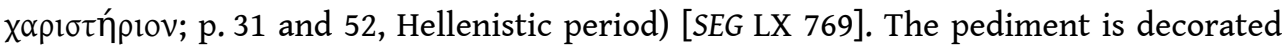
with an image of Helios in a chariot. 9) A bench was dedicated to Meter Pontia by Agathion (p. 31 and 54, ca. 300-250) [SEG LX 770]. 10) A priest for life made a dedication

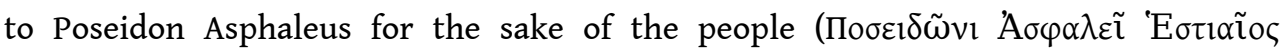

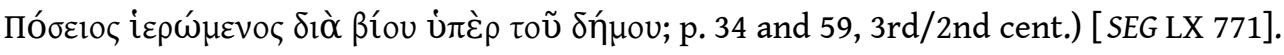

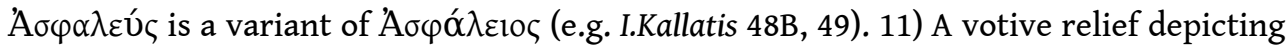
a small boy was dedicated by a man for his son ( 2nd cent.) [SEG LX 772]. 12) A table was dedicated to Meter Theon by a man from Tyros (p. 31 and 55, Hellenistic period) [SEG LX 774]. 13) An interesting dedication to Meter Theon Pontia, made by a priestess, describes her activities (p. 30 and 60, 1st/2nd cent.)

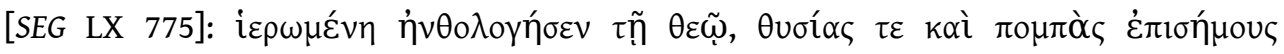

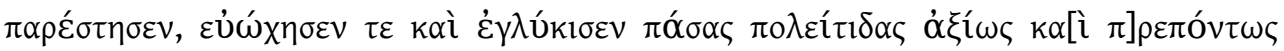
('while she was a priestess, she performed the rite of flower collection, offered sacrifices and processions in a distinguished manner, offered a banquet and sweet wine to all the female citizens in a worthy and proper manner'). 14) The text of a similar dedication by a priestess is not given (p. 30, 1st/2nd cent.) [SEG LX 776]. The priestess collected beautiful flowers ( $\tau \grave{\alpha} \kappa \alpha \lambda \grave{\alpha} \alpha$ óv $\theta \eta$ ) together with the female citizens and offered sweet wine to the council and all the women 'in accordance with the ancestral custom'. 15) Two brothers made a dedication to the Thracian Rider called "H $\rho \omega \varsigma$ $\Phi \dot{ } \lambda_{\alpha} \xi$ (p. 34, 2nd/early 3rd cent.) [SEG LX 777]. 16) A small altar was dedicated to Herakles as a $\delta \tilde{\omega}$ pov (p. 31 and 34, 2nd/3rd cent.) [SEG LX 778]; the dedicant was member of an association of worshippers of Athena. 17) A small altar was dedicated to an anonymous deity (p. 31, Imperial period) [SEG LX 779]. [Cf. the remarks of A. AVRAM, BE 2011, 448 and SEG LX 758-770. For the inscriptions see also I. LAZARENKO, E. MINCHEVA, R. ENCHEVA, N. Stoyanova, N. SHaRankov, The Temple of the Pontic Mother of Gods in Dionysopolis, Varna, 2013, p. 47-64].

107) B. LE GUEN, “L'association des Technites d'Athènes ou les ressorts d'une cohabitation réussie", in Individus, groupes et politique, p. 339-364: G. examines the connection between the association of the Dionysiac artists in Athens and the city of Athens. She argues that the association cooperated closely with the state in the organization of festivals and in diplomatic enterprises; therefore, it should not be 
regarded as entirely independent from the state. She also argues that the large majority of the members of the association possessed Athenian citizenship.

108) B. LEVICK, "Some Augustan Oaths", in S. CAGNAzzi et al. (eds.), Scritti di storia per Mario Pani, Bari, 2011, p. 245-256: After observing that the oaths of loyalty to the emperor drew on a variety of Greek and Roman models, L. observes that oaths of loyalty to emperors have a different tone and display varying degrees of aggressive vehemence against potential enemies. The oaths of loyalty to Augustus (Samos: IG XII 6 1, 7, 6/5 BCE; Conobaria in Spain: An.Ép. 1988, 723, 6/5 BCE; Phazimon in Paphlagonia: OGIS 532; IGR III 137; SEG LVII 1298, 3 BCE) display intense hostility, which can be explained by the context, that is, the recent arrangements for Augustus' succession. These oaths envisage as hostile elements those who would challenge the predominance of the direct male blood-line of Augustus through his former wife Scribonia and his daughter Julia; also Tiberius, who had gone into exile in $6 \mathrm{BCE}$, might have been envisaged as a potential threat. The initiative for these oaths possibly came from governors or local elites who 'were agog to know what their political leaders were about and to demonstrate loyalty, thereby winning credit' (253). The oath to Tiberius from Palaipaphos was taken at the initiative of the koinon of Cyprus (SEG XVIII 578; I.Paphos 151) and focused on local interests [republished and discussed by T. FUJI, Imperial Cult and Imperial Representation in Roman Cyprus, Stuttgart, 2013, p. 74-88, 188f.]. The oaths to Caligula from Aritium (ILS 190) and Assos (Syll. ${ }^{3}$ 797; I.Assos 26) are very different in tone. The oath of Aritium, a western community that had vivid memories of factional violence, is aggressive, whereas the Assos oath, introduced by an enthusiastic decree, simply calls down good on the Assians if they are faithful to the oath and the reverse if not. Such differences are the result of varying local awareness of metropolitan politics; oaths of loyalty are connected with the fact that intense rivalries were being played out throughout the Julio-Claudian dynasty [on this subject see also T. FuJI, "Typology of Inscribed Oaths to the Roman Emperors and Political Communication", in W. ECK et al. (eds.), Öffentlichkeit - Monument - Text. XIV Congressus Internationalis Epigraphiae Graecae et Latinae, 27.-31. August MMXII. Akten Berlin, Berlin, 2014, p. 613-615].

109) P.M. LIUzzo, "Osservazioni sulle iscrizioni del Trofeo di Platea e della colonna serpentina", Epigraphica 74 (2012), p. 27-41: After a detailed study of the literary sources concerning the victory dedication made in Delphi after the battle of Plataia (Herod. IX, 81, 1; Thuc. I, 132; III, 57; Dem. LIX, 97/98; Diod. XI, 33, 2; FgrH 104 F1; Paus. $X, 13,9$ ) and the inscription engraved on the serpentine column (now in Istanbul; Syll. ${ }^{3}$ 31; most recent editions: M. STEINHARDT, "Bemerkungen $\mathrm{zu}$ Rekonstruktion, Ikonographie und Inschrift des plataischen Weihgeschenkes", BCH 121 [1997], p. 33-69; SEG XLVII 535; Choix - Delphes [supra $\mathrm{n}^{\circ}$ 80] 17), L. proposes the following reconstruction of the history of this monument: originally, the inscription consisted of an epigram attributing the dedication to Pausanias; the epigram was deleted by the Spartans, and a list of the cities was inscribed around the vessel on the top of the column; the names of the cities were inscribed on the column during the Third Sacred War.

351 110) P. LOMBARDI, "Per sempre accanto al suo dio: la sepoltora di una Menade tebana vicino al teatro di Magnesia al Meandro (Inschr. v. Magnesia, 215)", Scienze dell'Antichità 14 (2007/2008), p. 547-565 [SEG LX 1255]: L. reprints the text of an inscription from Magnesia on the Maeander (I.Magnesia 215) concerning the cult of Dionysos. The inscription contains an oracular enquiry after the discovery of a statue of Dionysos and the response of the Delphic oracle recommending the introduction of Dionysos' cult 
from Thebes to Magnesia by three maenads. The texts were inscribed in the 2nd cent. CE by Apollonios Mokolles, a mystes, but they are much older. Since the enquiry mentions an eponymous prytanis, replaced by an eponymous stephanephoros in $221 / 20$, it was generally believed that the oracle was given before $221 / 20$. However, L. proposes to date the enquiry and the oracle to ca. 205-197, i.e. in the period in which the Delphic Amphiktyony, of which the Magnesians were members, was dominated by Thebes. She also points out that the cult of Dionysos Kadmeios was upgraded in Thebes in the late 3rd cent. (cf. CID IV 70); until that time, Orchomenos and Chaironeia had been the main centers of the festival Agrionia, connected with Dionysos. The enquiry was fabricated by Apollonios Mokolles in the 2nd cent. CE; in an effort to insinuate the oracle's antiquity, he dated the document by referring to an eponymous prytanis. $\mathrm{L}$.

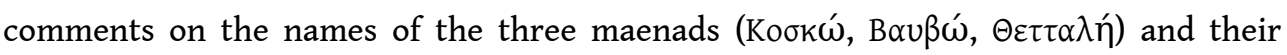

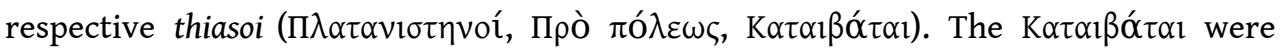
women who descended into a specific cult place from which they emerged carrying the image of the god - possibly also the image of Semele. From Thettale's burial near the theater, L. infers that the rituals of her thiasos were connected with the theater. [A small detail: The oracle mentions support offered by the Magnesians to Delphi (lines

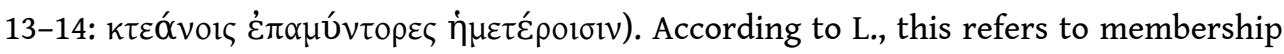
in the Amphiktiony and not to Magnesia's contribution to the defeat of the Gauls in

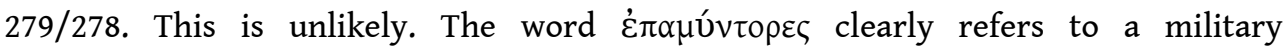
achievement. Magnesia's contribution to the defeat of the Gauls was an important part of Magnesian self-representation, mentioned in I.Magnesia 46 (208 BCE). I see no reason why an oracle dating to ca. 205-197 BCE (L.'s date) should not mention the invasion of the Gauls].

111) F. LozANo, "The Creator of Imperial Gods: Imposition versus Spontaneity", in More than Men, Less than Gods, p. 475-519: L. examines the exact circumstances of the introduction of the imperial cult in East and West and the part played by representatives of Roman authority and local elites. He argues that the appearance of the imperial cult should be approached from the perspective of cultural transformation.

112) A. MAKRES, "A New Fragment of a Fourth-Century BC Athenian Treasure Record", in Studies - Tracy, p. 63-71 [BE 2011, 184]: Ed. pr. of a fragment of an inventory of the treasury of Athena and the Other Gods (Athens, late 4th cent.), part of the known inventory IG $\mathrm{II}^{2}$ 1464. The new discovery permits a better restoration of this fragmentary inscription.

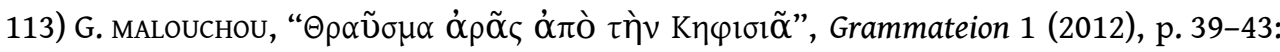

Ed. pr. of a small fragment of an inscription from Kephesia (early 2nd cent. CE) containing a curse against those who would destroy a statue. M. recognizes the new text as belonging to a well-known group of curses set up by Herodes Atticus against those who would damage statues of his wife Regilla and his deceased alumni (see PHILOSTRATOS, Vit.Soph. II, 559, and EBGR 1998, 260).

114) G. Malouchou, A.P. MATthaiou, “I [BE 2013, 341]: Ed. pr. of a fragmentary inscription from Chios (late 5th/early 4th cent.). It is a copy of an already known cult regulation that contains prohibitions against the use of groves for pasture and against the removal of objects from a sanctuary (LSCG 116). The new fragment (copy B) differs in some details from the already known copy (copy A). The passage which concerns people illegally throwing manure (A 14-17, B 11- 
15) seems to be better preserved in the new copy. The additional text of copy B is

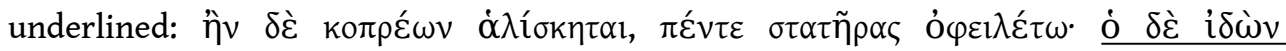

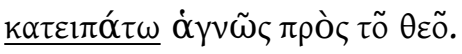

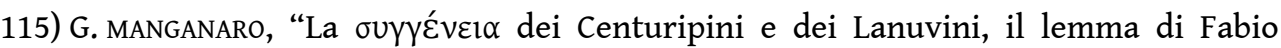
Pittore a Tauromenion e il fr. 23 Morel del Bellum Poenicum di Nevio", in C. DERoux (ed.), Corolla Epigraphica. Hommages au professeur Yves Burnand, Brussels, 2011, p. 549-561: An inscription from Centuripae contains a decree of the council of Lanuvium renewing the kinship between the two communities (SEG XLII 837; LVII 868, 1st cent.). M. associates with this tradition the summary of the work of Fabius Pictor presented in an inscription from the gymnasion of Tauromenion (SEG XXVI 1123; LIX 1131, 3rd/2nd cent.). According to the recent restoration by F. BATTISTONI (SEG LVI 1106), Fabius Pictor

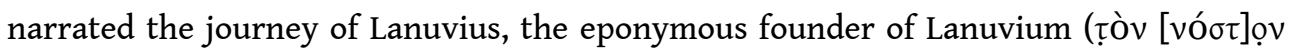
$\Lambda \alpha v o$ óv), an ally of Aeneas and Ascanius.

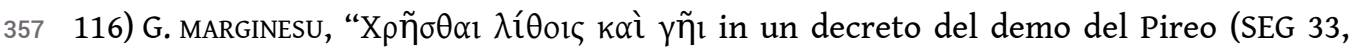
143, 1-7)", ZPE 180 (2012), p. 153-157 [BE 2013, 139]: A decree of Piraeus (IG II ${ }^{2} 1176+$ SEG XXXIII 143) provides for the use of stone and earth from a sanctuary of Dionysos. The decrees' subject is not the use of a stone quarry belonging to the sanctuary, as was previously thought, but the recycling of building material (cf. IG I3 78, 79; I.Oropos 292 lines 29f.).

117) P. maRTZavou, "Dream, Narrative, and the Construction of Hope in the 'Healing Miracles' of Epidauros", in Unveiling Emotions, p. 177-204: Through an analysis of the structure, style, and content of the collection of healing miracles in the Asklepieion of Epidauros (IG IV ${ }^{2} 1,121-124$, late 4th cent.), M. explains how this inscription evoked the emotions of hope and confidence among the people who came to the sanctuary of Epidauros in search of healing. She plausibly argues that these texts were sophisticated literary compositions that exploited detailed descriptions (enargeia) and dramatic elements (peripeteia) in order to lead their audience to metaphorical and literal catharsis through 'pity and fear'. She stresses the importance of dream experience in this process. The placement of the inscriptions with the narratives near the abaton and in close proximity to other inscriptions contributed to their emotional impact. The narratives were arranged in an order that gradually constructs the profile of the healing god and leads the reader from anxiety, uncertainty, and disbelief to trust and hope.

118) P. MARTZAVOU, "Isis Aretalogies, Initiations, and Emotions: the Isis Aretalogies as a Source for the Study of Emotions", in Unveiling Emotions, p. 267-291: M. argues that the aretalogies of Isis, written in stone and set up in sanctuaries, played an important part in rites of initiation. M. distinguishes between two types of texts, those in which Isis reveals her properties ('I am Isis'; Kyme: RICIS 302/0204; Thessalonike: RICIS 113/0545; Kassandreia: RICIS Suppl. 113/1201; SEG LVIII 583; Ios: RICIS 202/1101) and those in which the worshipper praises the goddess ('You are Isis'; Maroneia: RICIS 114/0202; IThracAeg E205; Andros: RICIS 202/1801). In addition to a discussion of these texts, M. also exploits the information provided by Apuleius' Metamorphoses XI concerning Isiac initiation. She argues that these texts were performed during the initiation ceremony, which she tentatively reconstructs as follows: first, the epiphany of the goddess was staged and the 'I-am-Isis' type of text was recited by a priestess in front of the initiates. Later, towards the end of the ceremony, the initiate responded with the 'You-are-Isis' type of text, sealing the pact between the goddess and the initiate. 
Through surprise and emotional arousal the performance of these aretalogies contributed to a specific perception of the divine: they underlined the role of Isis as an instigator of change and defined life-goals for the initiates.

119) F. MATEI-POPESCU, "Notes épigraphiques II", SCIVA 59/60 (2008/2009), p. 241-245 [AE 2008, 1202; BE 2011, 452; SEG LVIII 732; LIX 797]: Ed. pr. of a fragmentary inscription from Moesia (2, 2nd/3rd cent.), which M.-P. interprets as a dedication to Plouton and

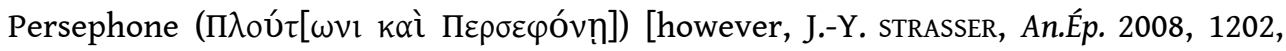
interprets this text as an epitaph, recognizing in $\Pi \lambda$ out [- - ] the beginning of the name of a deceased woman]. Ed. pr. of a fragmentary dedication of unknown provenance, somewhere in Moesia (3, ca. 150-200); only parts of the Thracian names of the dedicants are preserved.

120) F. MATEI-POPESCU, "A Greek Inscription from Tomis (MNA L 419)", in I. PISO et al. (eds.), Scripta Classica Radu Ardevan Sexgenario dedicata, Cluj-Napoca, 2011, p. 307-310 [An.Ép. 2011, 1146]: Ed. pr. of a dedication to the Theoi Patrioi by a Roman commander of a cavalry unit stationed in Arabia (unknown provenance, early 3rd cent. CE). The same officer also made a dedication to Heros Manibazos in Tomis (I.Tomis 127); Tomis is probably also the provenance of his second dedication [and since it is a dedication to Patrioi Theoi, Tomis is most likely to have been the officer's place of origin].

121) F. MATEI-POPESCU, "Note epigrafiche III", SCIVA 62 (2011), p. 265-273: New edition of a small altar of unknown provenance (Dacia or Moesia Inferior) in the National Museum of Antiquities in Bucharest (CIL III 8059, 3rd cent. CE). In line 1, M.-P. reads the word APA, i.e. the Latin ara written in Greek letters, as a designation of the altar.

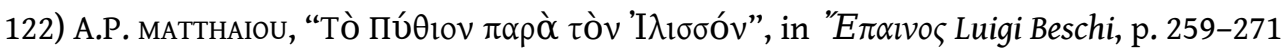

[BE 2012, 15; SEG LXI 36]: M. re-examines the literary, epigraphic, and archaeological evidence concerning the location of the sanctuary of Apollo Pythios. He proposes a location southwest of the Olympieion. The relevant inscriptions include an altar dedicated by Peisistratos, the son of the tyrant (IG $\mathrm{I}^{3} 948$ ), choregic monuments (IG $\mathrm{I}^{3}$ 963, 965; IG II² 2814, 3029, 3047, 3065-3067; SEG XXI 469; XXVI 220/221; XXVII 12-19), dedications (IG I ${ }^{3}$ 964; IG II ${ }^{2} 2789$ ), and vase inscriptions with the abbreviated epithet of

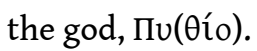

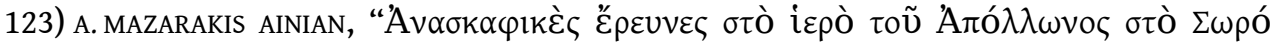
(2006-2008)", AEThStE 3, p. 287-298: Ed. pr. of an inscribed block, re-used for the construction of the base of a statue near the temple of Apollo at Soros (Thessaly,

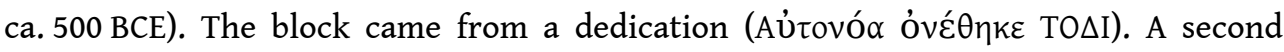
inscription on a block of the base preserves part of the sculptor's signature.

124) L. MERCURI, "Contributi allo studio degli spazi pubblici delii: L'agora di Teofrasto", ASAA 86 (2008), p. 193-214: M. discusses the epigraphic and archaeological evidence concerning the agora constructed by the Athenian epimeletes of 125 BCE Theophrastos (cf. I.Délos 1645). As the author infers from the large number of dedications and honorary statues from that area (I.Délos 1551, 1601, 1642, 1645, 1663, 1673, 1737, 1753/1754, 1777, 1807, 1845, 1850, 1869, 1957, 1969, 1978, 1989, 2011 bis, 2018, 2097, $2121,2151,2212,2233,2483,2496,2498,2505,2651)$, the agora fulfilled important functions as a place of religious worship and display of honors. From the heterogeneity of the dedicants and the divine recipients of the dedications (Herakles, Hermes, Poseidon Nauklarios, Zeus Ourios, and the Egyptian gods) one may infer that 
individuals of different origin, especially with connections to Alexandria and Rome, came together in this place.

125) L. MIGEOTTE, "La fondation d'Aristoménès et de Psylla à Corcyre", in Studi ellenistici 24, Pisa, 2010, p. 63-69 [BE 2011, 356; SEG LX 561]: In the early 2nd cent., Aristomenes and Psylla left an endowment for the funding of dramatic contests in Korkyra (IG IX ${ }^{2} 1$, 798). As M. explains, the modalities for the administration of the funds indicate tensions between the donors and the city. Since the original sum (120 mnai) was insufficient for the festival's budget (180 mnai), the original capital and the generated interest were to be annually lended at a high interest rate of $16 \%$, until the amount of 252 mnai and 4 drachmas was reached in the fifth year. The arrangement also took into consideration the eventuality of delayed payments.

126) A. MINCHEV, "Greek Traditions and Roman Taste: Continuity and Change in Odessos/Odessus (3rd c. B.C.-3rd c. A.D.”, in I.P. HAYNES (ed.), Early Roman Thrace: New Evidence from Bulgaria (JRA Suppl. 82), Portsmouth, RI, 2011, p. 15-39: The archaeological and epigraphic evidence from Odessos from the 3rd cent. BCE to the 3rd cent. CE reveals the persistence of Greek traditions and the introduction of Roman cultural elements. The principle deity in Hellenistic Odessos was A $\pi$ ó $\lambda \lambda \omega v \Delta \varepsilon \lambda \varphi$ ívioc; in the

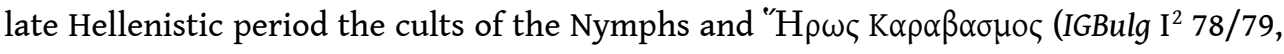
284-290), the local version of the Thracian Rider, were introduced. In the Imperial period, when a large portion of the population consisted of Hellenized Thracians, Odessos received Roman settlers and traders from Asia Minor. Thracian deities were very popular, also among the Greek population. The most important religious developments are the introduction of the imperial cult, the cults of Dea Roma, Mithras, and Roman deities (Sol Invictus, Mars, Silvanus, Concordia), and the popularity of $\Delta \alpha \rho \zeta \alpha \lambda \alpha \varsigma$. Darzalas, Poseidon, and Apollo were served by one priest (IGBulg I ${ }^{2}$ 67).

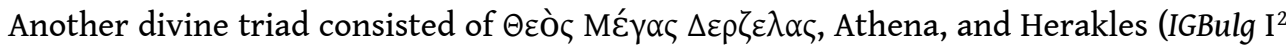

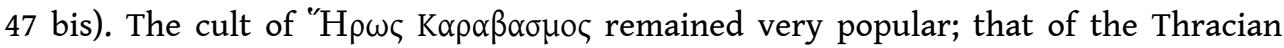
Rider was connected with the cults of Darzalas and Apollo. M. gives an overview of contests, festivals, and gladiatorial events in Roman Odessos. M. mentions two unpublished inscriptions: an inscription that records the dedication of marble benches in the temple of Apollo Delphinios (p. 19, 5th/4th cent.) and an inscription that refers to the appointment of a highpriest of the imperial cult for life and mentions the cult of Thea Rhome (p. 27).

127) N.P. MILNER, "The Remaining Inscriptions from the Balboura Survey Project", in J.J. COULTon et al., The Balboura Survey and Settlement in Highland Southwest Anatolia, Ankara, 2012, II, p. 83-127: M. presents inscriptions found during the Balboura survey and not previously presented in earlier articles (new texts are marked with an asterisk). An honorific inscription ( 4 = IGR III 476; SEG XXVIII 1217, mid-2nd cent. CE) lists the

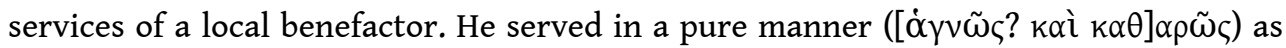
priest of Zeus Philios, Herakles, and Ares, making the suitable dedications to these gods; together with his wife he served as priest of the civic imperial cult, dedicating a gilt-bronze statue of Antoninus Pius and offering a banquet to the city. [M. reads

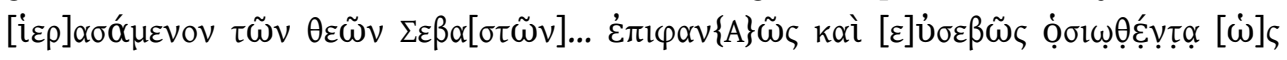

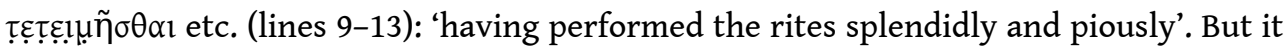
is difficult to interpret óøió $\omega$ (in the middle-passive) as 'to perform rites'; I suspect $\dot{\omega} \varsigma . . . . . . .[.] \varsigma \tau \varepsilon \tau \varepsilon \downarrow \mu \tilde{\eta} \sigma \theta \alpha$, i.e. $\dot{\omega} \varsigma$ followed by an adverb that specifies the manner in which

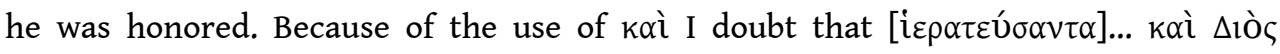




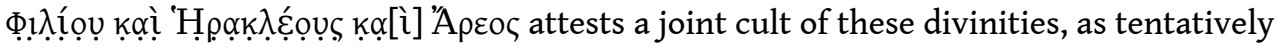
assumed by $\mathrm{M}$. These are three separate priesthoods, possibly held at the same time by the honorand]. Other inscriptions include the dedication of a statue of Dionysos (5), a dedication to gods $\left(14^{*}\right)$, and a dedication to the emperor Vespasian (1). M. interprets

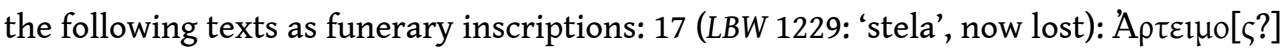

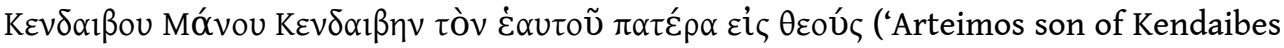
son of Manes (set it up for) Kendaibes, his own father; to the spirits of the departed');

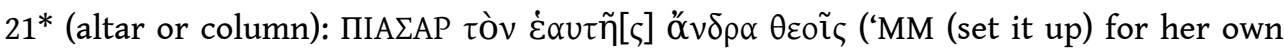
husband, to the Spirits of the Departed'). [But $\theta \varepsilon o$ í, without any further specification, are 'gods' and not the 'spirits of the departed'. The dedicants set up 'his father' and 'her husband' respectively, i.e. their images, and not 'it' (the stele or column). These inscriptions record the dedication of images (honorific statues?, paintings?). They are posthumous honors but not epitaphs. The same applies to $n^{\circ} 29$ (block, possibly a statue

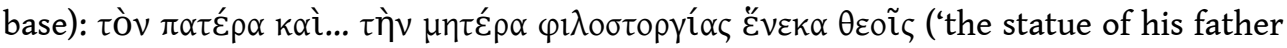
and the statue of his mother for affection's sake to the gods'; not: 'in loving memory to the spirits of the departed'). These texts are dedications to the gods and should be distinguished from other epitaphs in which the name of the deceased is in the accusative (e.g. 22, 23, 32, 34, and 40)]. A sacred slave is mentioned in an epitaph (35): a man erected the grave for himself, his wife, his son, and a hieros. We note three

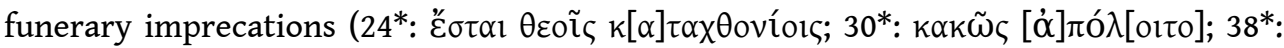

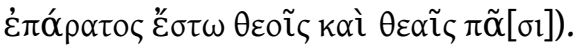

128) S. MITCHELL, "Further Thoughts on the Cult of Theos Hypsistos", in One God, p. 167208 [SEG LX 2036]: In this significant contribution to the study of monotheistic trends in the Roman Empire, M. returns to the problem of how the epigraphic evidence for Theos Hypsistos should be interpreted. Was there a conceptual unity in the worship of Hypsistos, or is the epithet hypsistos a generic adjective applicable to many forms of divinity? M. defends the idea that a common cult of Theos Hypsistos could emerge in the Roman Empire. Important features of this cult were its aniconic character, the absence of animal sacrifice, the existence of adjutants (angels), and the role of the eagle in religious iconography. For the majority of the worshippers the god remained anonymous but a significant minority identified Theos Hypsistos with Zeus. In some cases a connection between 'god-fearers' $(\theta \varepsilon \circ \sigma \varepsilon \beta \varepsilon \tilde{\varepsilon} \varsigma)$ and worshippers of Theos

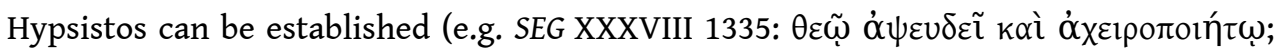

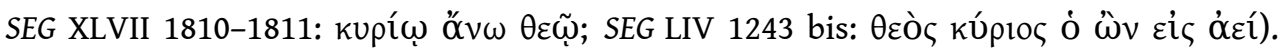
Although the cult of Theos Hypsistos 'was not rigorously exclusive' (p. 180), very few texts refer to other gods, directly or indirectly. Theos Hypsistos was not normally conceived as being integrated into the wider pantheon of deities. In an appendix (p. 198-208), M. presents addenda to his catalogue of inscriptions mentioning Theos Hypsistos (83 inscriptions) [cf. EBGR 198, 190].

129) S. mitchelL, "Votive Monuments from South West Asia Minor", in H. вöRM, N. EHRHARDT, J. WIESEHÖFER (eds.), Monumentum et instrumentum inscriptum. Beschriftete Objekte aus Kaiserzeit und Spätantike als historische Zeugnisse. Festschrift für Peter Weiß zum 65. Geburtstag, Stuttgart, 2008, p. 154-175 [BE 2009, 30; SEG LVIII 1564]: Ed. pr. of a dedication to the Theai Hagnai Epekooi from Sagalassos (ca. 150 CE; p. 167f.; mentioned in SEG XLVII 1761.3). The inscription, inscribed on a column decorated with a fragmentary relief, records two dedications. Briseis, a priestess, dedicated at her own

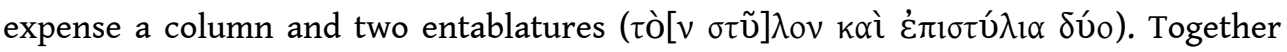


with another woman, the same priestess also dedicated the entablature at the entrance

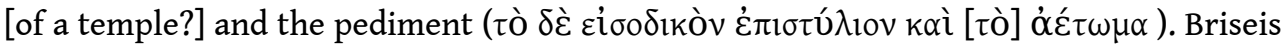
also served as priestess of Angdistis (SEG XXX 1508). In Late Antiquity (5th cent. CE), the

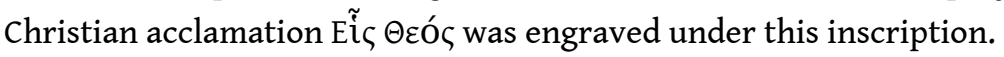

130) J.D. muccigrosso, J. higGinBotham, "A New Archaic Dipinto from Poseidonia", ZPE 178 (2011), p. 191-194: Ed.pr of a cup from Poseidonia, reassembled from many fragments (ca. 550-500). A very fragmentary dipinto seems to record the dedication of

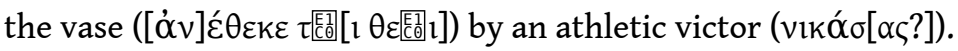
131) H. MÜLLER, "Hadrian an die Pergamener. Eine Fallstudie", in R. HAENSCH (ed.), Selbstdarstellung und Kommunikation. Die Veröffentlichung staatlicher Urkunden auf Stein und Bronze in der römischen Welt, Munich, 2009, p. 367-406 [BE 2011, 498; SEG LX 1423-1424]: M. presents a new edition of Hadrian's letter to Pergamon in response to the city's request to build a third temple for the provincial emperor cult (I.Pergamon 276+277, December $137 \mathrm{CE}$ ). After thanking the Pergamenes for their zeal, the emperor points out that the city already has two large temples (for Roma and Augustus, and for Trajan and Zeus Philios), contests, and exemption from taxes during the festivals. The cost for a third temple would endanger the funds for the existing temples and contests ( $\left.\delta v_{0}\right] \tau \varepsilon$

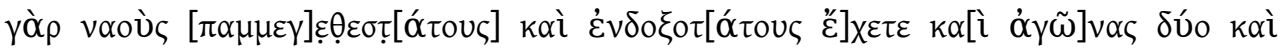

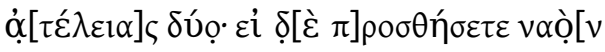

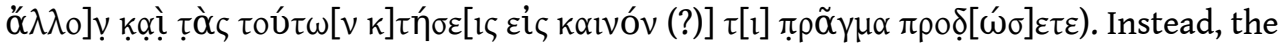
emperor allowed them to set up his statue in Trajan's temple next to Trajan's statue

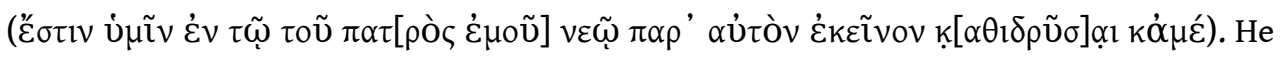

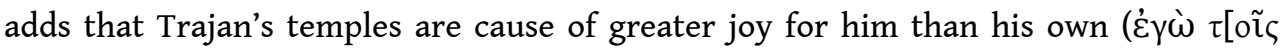

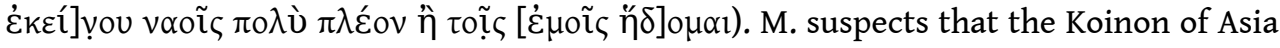
was not prepared to earmark additional revenues for a third provincial temple in Pergamon; the expenses would have to have been borne by the city. In an appendix, M. (p. 393-406) presents a new edition of I.Pergamon 272, adding three further fragments. The text is a copy of a letter of Trajan to Pergamon and a senatus consultum concerning the promotion of the contest Traianeia Diiphilia to a pentaeteric and eiselastic agon (115 CE). The contest for Trajan and Zeus Philios was given the same privileges as 'the other sacred contest', i.e. the agon for Roma and Augustus. The dossier was published in the Traianeion, together with a second version (I.Pergamon 269). Pergamon managed to establish a second temple for the provincial emperor cult after sending at least three embassies to the emperor, probably in order to overcome the objections of Ephesos and Smyrna.

132) F. MUSCOLINo, "Il bollo laterizio EPMAHPAK $\Lambda E O \Sigma$ a Taormina", ZPE 182 (2012), p. 223-242: M. studies a group of stamped tiles from Tauromenion (3rd-1st cent.); the

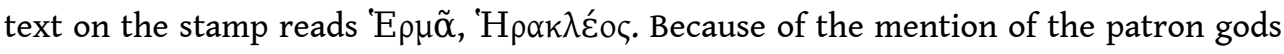
of the gymnasion, $\mathrm{M}$. attributes these tiles to the gymnasion.

133) Vacat.

134) J. MYlONOPoulos, "Divine Images Behind Bars. The Semantics of Barriers in Greek Temples", in Current Approaches to Religion, p. 269-291: M. collects the evidence for barriers of wood, metal, or stone in front of the cult statue in Greek temples. Not all

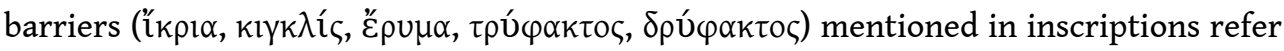
to barriers in front of statues; they may refer to screen walls in the intercolumniations. But there is firm evidence for barriers in front of statues in temples in Aigina, Athens, 
Sounion, Epidauros, Kleonai, Lindos, Lykosoura, Olympia, Priene, and possibly Delos. After critically examining various hypotheses for the existence of barriers (protection of valuable or famous statues, the existence of tables for offerings, aesthetic considerations), M. proposes a different interpretation. Adducing cult regulations that attest the regular or daily opening of temples (LSAM 5, 28; LSCG 69; Iscr.Cos ED 236), he argues that these barriers both created a boundary and regulated the movement in temples that were accessible on a daily basis, making the area around the statue inviolable.

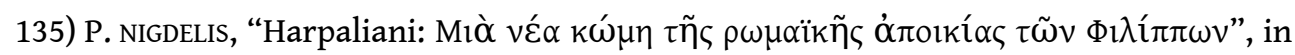
Diniessa - Romiopoulou, p. 103-110: Ed. pr. of a Latin inscription on a funerary altar from the territory of Philippi (2nd cent. CE). The text records the bequest of 250 denarii to the Harpaliani, inhabitants of a vicus of Philippi, by Bacchanius Bizes. The recipients of the bequest were obliged to use the revenues in order to provide an annual sacrifice at the man's monument, celebrate a feast on the occasion of the rosalia (adalant [et] vescantur Rosis), and fund the gymnasium. In case of violation of the testator's wish, the money would be given to a cult association of worshippers (sancti cultores) of Iupiter Optimus Maximus.

136) P.M. NIGDELIS, "The Roman Calendar and its Diffusion in the Greco-Roman East: The Evidence of the Personal Name Kalandion", in Onomatologos, p. 617-627 [SEG LX 1980]: N. collects the evidence for the diffusion of personal names deriving from Kalendae in the

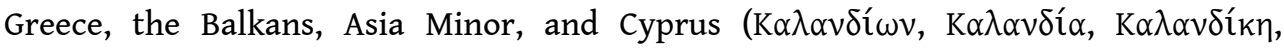
Kó $\lambda \alpha v \delta \circ \varsigma, K \alpha \lambda \alpha v \delta \alpha$ ploc) and examines the cultural and religious context of this phenomenon. Several factors may explain the familiarity of the Greeks with the word Kalendae: the diffusion of the festival of Kalendae Ianuariae; the use of the Roman calendar in financial transactions involving Roman creditors. Children born on the first day of the month were given related names (cf. the Greek name Noupńvios).

137) P.M. NIGDELIS, A. ARVANITAKI, "Direct Taxation in Roman Macedonia: a New Votive

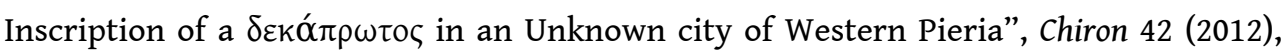
p. 271-286 [SEG LX 644]: Ed. pr. of an inscription that records a dedication made to Asklepios and Hygieia by a dekaprotos of an ancient city near Elatochori (perhaps Phylakai?, 73/74 CE) [see supra $\mathrm{n}^{\circ} 13$ ]. The dekaprotoi were responsible for the collection of the direct taxes payable to the imperial treasury. Timoxenos financed the construction of a temple on the occasion of their election to some office, either as summa honoraria or as a voluntary contribution.

138) A. ochat-CZARnowicz, "The Cult of Achilles on the Coast of the Black Sea", in E. PAPUCI-WEADYKA et al. (eds.), Pontika 2008: Recent Research on the Northern and Eastern Black Sea in Ancient Times, Oxford, 2011, p. 269-274: A mosaic in Amisos (SEG LIII 1427 and LV 1391, early 3rd cent. CE) [EBGR 2005, 137] depicts Achilles and Thetis in a central panel

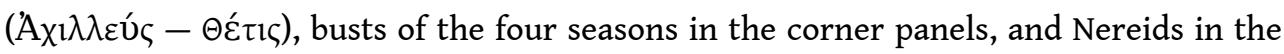
side panels. The bottom section displays a sacrificial scene. The author returns to the suggestion that the presence of a sacrificial scene attests an otherwise unknown cult of Achilles in Amisos (see EBGR 2005, 137). Adducing evidence for the cult of Achilles in the North Pontic region, she tentatively suggests that the bottom section depicts a bull sacrifice to Achilles. [No reference to J. HUPE (ed.), Der Achilleus-Kult im nördlichen Schwarzmeerraum vom Beginn der griechischen Kolonisation bis in die römische Kaiserzeit. Beiträge zur Akkulturationsforschung, Rahden, 2006. In the Amisos mosaic, the sacrificial 
scene is clearly separated from the depiction of Achilles and Thetis; therefore, it cannot serve as evidence for a cult of Achilles.]

139) J. OULHEN, "HРОПҮ $\Theta O \Sigma$. Une pousse printanière pour Elaine Matthews?", in Onomatologos, p. 628-645 [SEG LX 1982]: Several personal names with the element - $\pi v \theta 0$ S

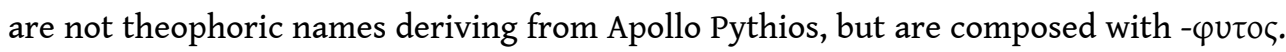

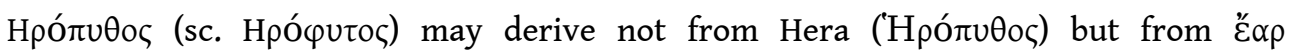

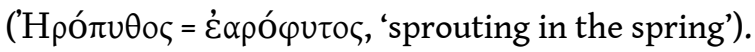

140) A. OVADIAH, "The Roman Altar Dedicated to Zeus from Velico Târnovo - Bulgaria Reconsidered", Gerion 29, 2 (2011), p. 35-39: An altar dedicated to Zeus from Veliko Tarnovo (Nikopolis ad Istrum, 2nd/3rd cent., IGBulg $V$ 5252) is decorated with a thunderbolt of unusual shape. $O$. recognizes a combination of a thunderbolt and an ant. According to mythology, Zeus deceived Eurymedousa in the disguise of an ant and had intercourse with her; for this reason, her son was called Myrmidon (from $\mu$ v́ $\rho \mu \eta \xi)$ ).

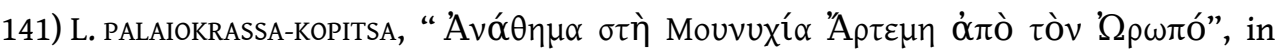
Namata - Pandermalis, p. 217-224: Ed. pr. of an inscribed naiskos-base supporting a metrical dedication to Artemis Mounichia (ca. 350 BCE). Exekestos and Kleino dedicated

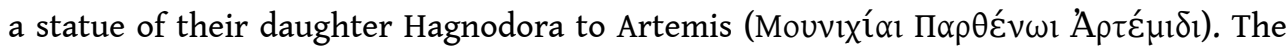
base was found re-used in Oropos, but its provenance seems to be Brauron, where Exekestos served as epistates (IG $\mathrm{II}^{2}$ 1524). The Acropolis inventories mention Kleino as a dedicant to Artemis Brauronia.

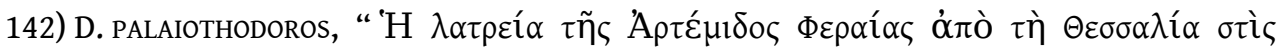

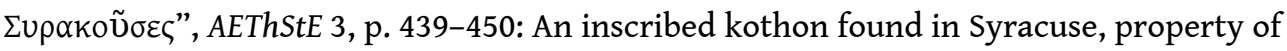

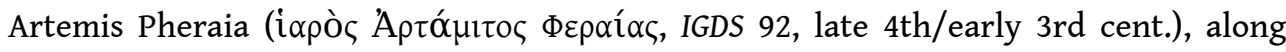
with a dedication to Artemis Pheraia seen by Cyriacus of Ancona in Issa are the only epigraphic testimonia for the cult of Artemis Pheraia (L. ROBERT, Hellenica XI/XII, Paris, 1960, p. 591 note 4). An inscription with exactly the same text on a lekythos of unknown provenance is a modern forgery. According to Pausanias Artemis Pheraia was also worshipped in Sikyon (II, 10, 7 and II, 23, 5). The prevailing view is that Artemis Pheraia can be identified with Ennodia; this assumption is based on the observation that Ennodia is one of the six goddesses mentioned on an altar at Pherai (SEG XLV 645), whereas Artemis is not. It is also assumed that Ennodia was assimilated with Artemis, when her cult was transferred from Thessaly to other areas. P. снRYsostomou ( $\mathrm{H}$

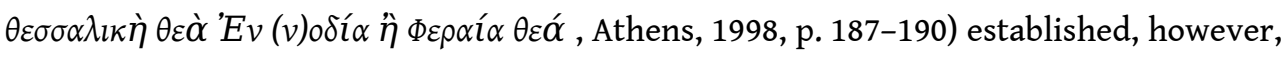
that there were separate cults of Artemis and Ennodia in Pherai, although he assumed that the two cults were conflated. P. argues that the two cults were and remained separate. In his view, the epithet Pheraia does not refer to Ennodia but to the origin of specific rituals connected with the cult of Artemis in Pherai. The goddess was connected with rites of passage of children, as P. infers from the dedication made by a woman for her children (снRуsоsтомоU, op.cit., p. 188f.). P. speculates that the transfer of the cult to areas outside of Thessaly may have taken place upon divine command, to appease the angry goddess. He attributes the diffusion of the cult to the relations between Corinth and Syracuse. The vase was found in a deposit near a sanctuary of Demeter and Kore. For this reason, it has been suggested that the cult of Artemis Pheraia was chthonic in nature. Examining the other finds from the same well, P. argues that music and dance were important aspects of her cult. 


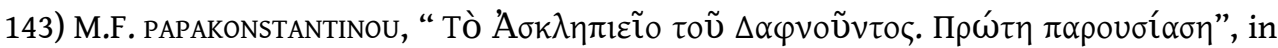
AEThSt 3, p. 1236-1247: The author summarizes the results of an excavation at the sanctuary of Asklepios in Agios Konstantinos, ancient Daphnous (Eastern Lokris). The sanctuary existed from the 5th to the early 1st cent. BCE. The excavations have revealed a temple, an incubation room (?), an altar, a banquet hall (?), and open spaces. P. mentions three graffiti on vases dedicated to Asklepios. Two of them name the god in the dative, the third designates the vase as sacred property (hiopóv).

144) D. PAPANIKOlaou, "IG V.2.268 (= SIG $\left.{ }^{3} 783\right)$ as a Monument of Hellenistic Prose", ZPE 182 (2012), p. 137-156: P. presents a critical edition of an honorific decree of Antigoneia (Mantineia) for the local benefactor Euphrosynos and his wife Epigone (IG V 2, 268, late 1st cent.) and offers an excellent analysis of its style (rare words, rhythmical clausulae, metaphors). This decree is a good example of Hellenistic oratory and late Hellenistic sophistic style. We note that the orator highlights the couple's services to the city's

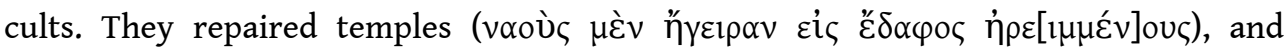
Epigone served as priestess, conducting the rituals, celebrations, and banquets in a

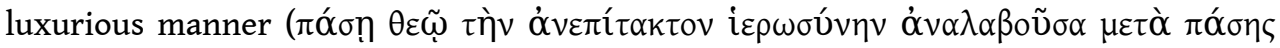

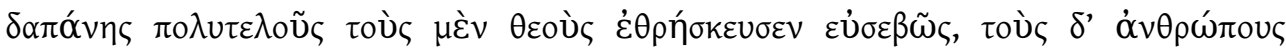
$\varepsilon \dot{\omega} \omega \dot{x} \eta \sigma \varepsilon \pi \alpha v \delta \eta \dot{\eta} \mu \omega \varsigma)$.

145) N. PAPAZARKADAS, Sacred and Public Land in Ancient Athens, Oxford, 2011: This book is the first systematic treatment of the evidence concerning the ownership of land by the Athenian state, its subdivisions (tribes, demes, phratries, gene, orgeones) and its gods or sanctuaries, the administration of this property and the officials responsible for this task. P.'s study is an important contribution to the study of the financial aspects of Athenian religion and the revenues of sanctuaries. He provides detailed discussions of the use of sacred land, especially its leasing, the setting of boundary stones, the use of the revenues from sacred land, the protection of sacred land by the Athenian army, and other legal, economic, religious, and political aspects. Needless to say that inscriptions, especially texts from Eleusis (I.Eleusis 144, 177) and leasing records, take the lion's share of the evidence. In many cases P. proposes new readings, dates, and interpretations. Among the subjects of religious interest that are discussed in the book and in appendices, we single out the discussion of the property belonging to Demeter and Kore of Eleusis, the hiera orgas (IG II $292=$ I.Eleusis 144), the olives belonging to Athena (moriai) and the use of their produce for the prizes of the Panathenaic contests (cf. IG II ${ }^{2}$ 2311), the initiatives of Phanodemos for the cult of Amphiaraos (I.Oropos 297), the cults of the genos of the Salaminioi and the conflicts that arose from the split of this group (SEG XXI 527).

146) E.K. PETropoulos, "Apollo's Cult in the Black Sea Area and the Greek Colonists: Some Remarks", in Ancient Sacral Monuments, p. 283-293 [BE 2011, 444; SEG LX 755 bis]: P. discusses the diffusion of the cult of Apollo in Thrace (Apollonia Pontike), Moesia (esp. Histria, Kallatis), and the North Shore of the Black Sea (esp. Olbia) [A. AVRAM, BE 2011, 444, points out omissions in the bibliography. With regard to Apollonia Pontica, the main sanctuary of this city was the sanctuary of Apollo Ietros (IGBulg $\mathrm{I}^{2} 388$ bis)].

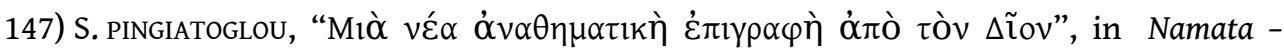
Pandermalis, p. 197-206 [BE 2013, 261; SEG LXI 490]: Ed. pr. of a marble base in the shape of a table, possibly from the sanctuary of Demeter in Dion (late 5th/early 4th cent.). The base was dedicated to Praxidika and Hermes Tychon. This is the first attestation of

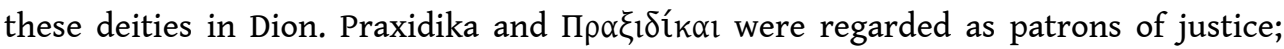


Tychon, associated with Hermes (I.Magnesia 203) and Priapos, was a patron of luck. Praxidikai and Hermes are jointly invoked in curses from Athens and Eretria. Being chthonic deities, they were probably worshipped as patrons of fertility.

148) H.W. PLEKET, “An Agonistic Inscription from Sardis", ZPE 181 (2012), p. 102-107 [BE 2013, 374]: P. discusses a fragmentary inscription from Sardeis (SEG XLVII 1653), with which the international association of athletes honored an anonymous emperor. P. proposes a date between ca. 120-180. The inscription was erected under the supervision of a xystarches for life of the contests in Sardeis. Presumably, these contests included the Chrysanthinos Agon and the contest of the Koinon of Asia.

149) H.W. PLEKET, "Fraudulent Agonothetes", ZPE 180 (2012), p.158: The letters of Hadrian to the Dionysiac technitai $(E B G R 2007,111)$ address the problem of agonothetai who did not pay the prize-money to victorious contestants. This common fraud explains why an agonothetes at Gerasa (SEG VII 825) is praised for honesty with regard

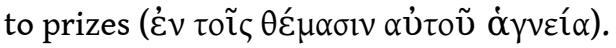

150) S. PRIGNITZ, “Ein Augustuspriester des Jahres 27 v. Chr.", ZPE 178 (2011), p. 210-214: P. discusses the date of the building inscription of the bouleuterion of Kalindoia (Macedonia, SEG LVIII 578), which had rooms dedicated to the imperial cult. This text is dated to the 120th year of an era. It has been assumed that this is a reference to the Actian era ( $88 \mathrm{CE})$, but p. presents plausible arguments in favor of a date in $27 \mathrm{BCE}$ (Macedonian era). If this date is correct, Arrhidaios, who is mentioned in this text as priest of Zeus, Roma, and Imperator Caesar Augustus, was the first priest of the imperial cult [conceivably, a joint cult of Zeus and Dea Roma already existed, and Augustus was added to this cult].

151) G.H. RENBERG, “Was Incubation Practiced in the Latin West?", ARG 8 (2006), p. 105147: A survey of the literary, archaeological, and epigraphic evidence from sanctuaries of healing gods in Italy and the Latin West shows that incubation, divinatory and therapeutic, was not widespread. The only sanctuaries for which there is reliable evidence belonged to Greek gods or show influence from non-Roman worship (the cult of Egyptian gods). Two inscriptions of uncertain provenance in Rome (IGUR 105 and 148) and literary evidence concerning the Asklepieion in Taras (Julian, Gal. 198.2) can be associated with incubation; by contrast, however, the inscriptions mentioning $\varphi \omega ́ \lambda \alpha \rho x o 1$ in Eleia do not prove the practice of incubation. In the West, sanctuaries associated with sacred springs did not necessarily practice incubation: it is attested with certainty only for the shrines of Kalchas and Podaleirios at Mt. Drion. A dedication to Somnus and Asklepios in Reii (ILS 3855; cf. Greek dedications to Hypnos and Asklepios: I.Ephesos 4123; I.Cret. I xvii, 24; SEG XXII 268, 293; IG II ${ }^{2} 4467$ ) implies an epiphanic dream but does not prove that this dream occurred during incubation in a sanctuary. Also dedications made ex visu cannot be taken as proof for this practice. Equally ambiguous is a cult regulation concerning purity in a sanctuary of Asklepios in Thuburdo Maius (Africa Proconsularis, ILAfr 225).

152) M. RICL, "A New Inscription from the Cayster Valey and the Question of Supernomina in Hellenistic and Roman Lydia", in Onomatologos, p. 530-551 [SEG LX 1161]: Ed. pr. of a fragmentary honorific inscription for an anonymous magistrate of Ephesos (ca. $200 \mathrm{CE}$ ), who was a descendant of prominent ancestors, including

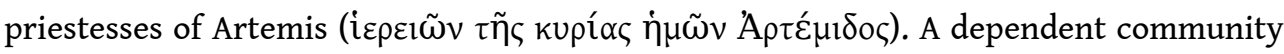
of Ephesos (the village of the Boneitai?) set up his statue for his services; the man was 
$\pi \alpha v \eta \gamma u p i \alpha \rho x о \zeta$ of the village. The men who were responsible for the erection of the statue include the descendant of a neopoios, who is mentioned in I.Ephesos 3239.

153) M. RICL, H. MALAY, "Two New Decrees from Iulia Gordos and Lora”, EA 45 (2012), p. 74-87 [BE 2013, 375]: Ed. pr. of two posthumous honorific decrees from Iulia Gordos. The first text is a rhetorically elaborate decree of Iulia Gordos and Lora for Attalos, a deceased statesman (1st cent. CE), the second text a decree for his grandson (69/70 CE). Both decrees make provisions for the closing of the baths (the first decree) and the baths and workshops (the second decree) on the day of the benefactors' funerals

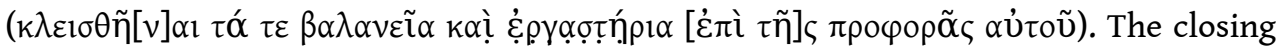
of workshops is attested in IOSPE I $\mathrm{I}^{2} 34$ lines 23f. and SEG XXVIII 953 lines 39-42. The stelai were to be erected near these men's graves. The stelai and the graves are

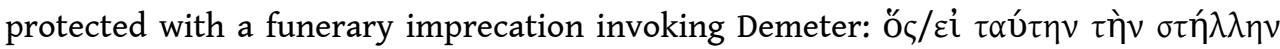

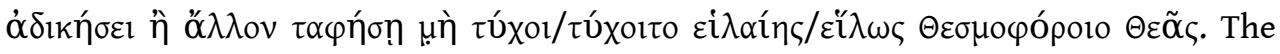

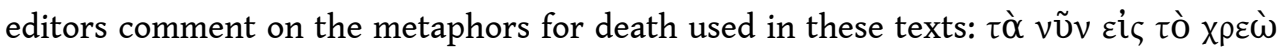

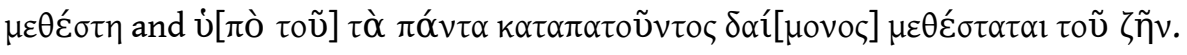

154) T. RITTI, "La carriera di un cittadino di Hierapolis in Frigia", CCG 19 (2008), p. 279308 [BE 2011, 570; SEG LVIII 1510]: R. republishes an honorific inscription for C. Memmius Eutychos (Hierapolis, ca. 214-217; SEG LIII 1464) and comments on his

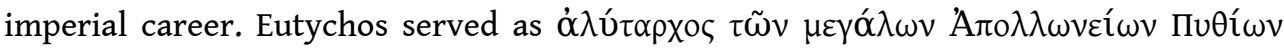
(lines 13-15; cf. I.Side 134). As one can judge from the office of the alytarchos/alytarches, the Apollonia had been organized following the model of the Olympic games.

155) F. RocCA, "Le iscrizioni di manomissione dal Cabirio di Lemno", ASAA 88 (2010) [2012], p. 289-308 [SEG LX 925-937]: Four stelai with manumission records have been found in the Kabireion of Lemnos (S. ACCAME, "Iscrizioni del cabirio di Lemno", ASAA 1921 [1941-1943], p. 94-99 $\left.\mathrm{n}^{\text {os }} 14-16\right)$. R. presents improved editions of the texts and reports on the discovery of a new fragment.

156) E. Rosamilia, “Un iscrizione inedita da Cirene nell'archivio Breccia”, Studi Ellenistici 24 (2010), p. 289-295 [BE 2011, 648; SEG LX 1836]: Ed. pr. of a dedication made by Kletomachos, during his service as a priest, probably of Apollo (Kyrene, ca. 260$250 \mathrm{BCE})$.

157) D. ROUSSET, De Lycie en Cabalide. La convention entre des Lyciens et Termessos près d'Oinoanda. Fouilles de Xanthos X, Geneva, 2010 [BE 2011, 554; SEG LX 1545, 1546, 1559, 1569]: R. presents the ed.pr. of an important inscription containing a treaty between the Termessians-near-Oinoanda and the Lycian League (Xanthos, ca. 160-150) [SEG LX 1569]. Following an arbitration by Koan judges, the treaty resolved a dispute between Termessos Minor and Tlos and Kadyanda concerning the possession and exploitation of Mt. Masa. We note an interesting detail in the description of the border; one of the points of orientation was a wooden Hermaion placed on a road, which R. interprets as a

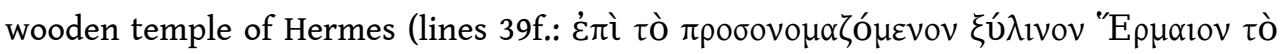
$\dot{\varepsilon} \pi \grave{l} \tau \tilde{\eta} \varsigma$ ódoṽ). The text is dated with references to eponymous priests: the priests of Roma and Apollo (Lykian Koinon) and the priests of Zeus and Roma (Termessos Minor). The treaty was to be published in the sanctuaries of Leto in Xanthos, Artemis in Tlos, Zeus in Termessos Minor, and in a sanctuary in Kaunos that was yet to be determined by the Kaunians. In this study, R. also presents two other inscriptions of religious interest. The most interesting is a funerary altar from the area of Oinoanda (p. 154f. $\mathrm{n}^{\circ}$ 8, Imperial period) [SEG LX 1545]. The altar is decorated with a relief representing two 


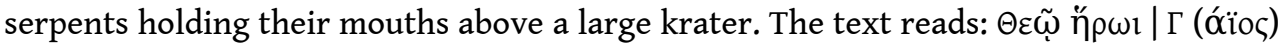

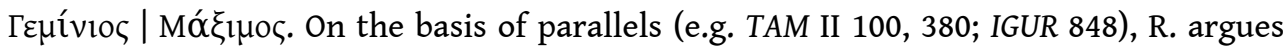
that this is not a dedication to a hero but the epitaph of a 'défunt divinisé'. The

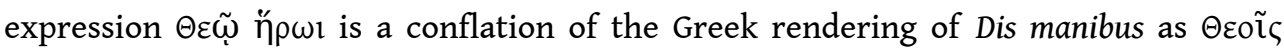
"H $\mathrm{\rho} \omega \sigma \mathrm{lv}$ and the designation of the deceased individual as a ed.pr. of a votive relief dedicated to Kakasbos, $\theta \varepsilon o ̀ \varsigma ~ \varepsilon \dot{\pi} \eta \dot{\kappa o o \varsigma, ~ i n ~ f u l f i l l m e n t ~ o f ~ a ~ v o w ~}$ (from Seki, in the territory of Termessos or Oinoanda, Imperial period, 158f.) [SEG LX 1546]. The relief represents a rider holding a club in his right hand. Finally, R.

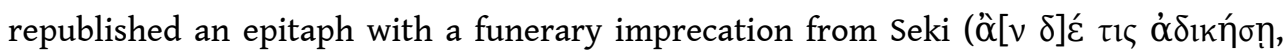

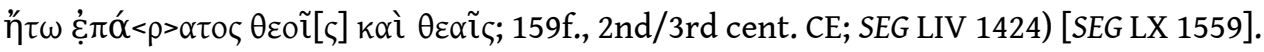
158) D. RousSET, "Les inscriptions antiques de Phocide et de Doride", CRAI (2012), p. 1659-1689: In an overview of epigraphic research in Doris and Phokis, R. presents an improved reading of an interesting funerary stele from Boulis in Phokis (p. 1665-1668) [3rd cent. CE or later?; mentioned in SEG LIX 545]. The stele was set up for Euemeros, who is designated as heros. An interesting feature is the representation of the Thracian Rider, rare in this region. R. also mentions an inscribed bronze sheet found in a cave on Mt. Parnassus (site Ambouria, near Patronis; 3rd cent. BCE; p. 1070f.). It records a

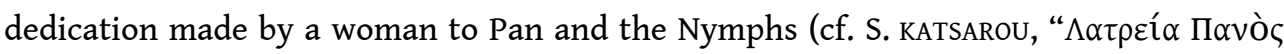

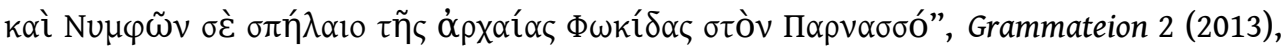
p. 33-40). [Judging from the suspension hole on the left, this sheet was suspended on the votive object, as a label].

159) D. Rousset, G. zachos, "Aus der Arbeit der 'Inscriptiones Graecae'. Nouveaux monuments inscrits de Tithoréa de Phocide", Chiron 42 (2012), p. 459-486 [BE 2013, 210]: Ed. pr. of four manumission records from the sanctuary of Sarapis in Tithora (ca. 100 $\mathrm{CE})$. The acts of manumission were inscribed on orthostates, found re-used in a Christian basilica. The texts are formulaic, usually containing an invocation ( $\Theta \varepsilon o ́ c$

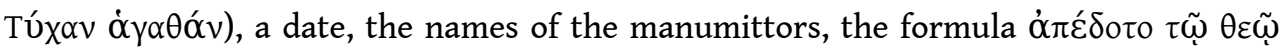

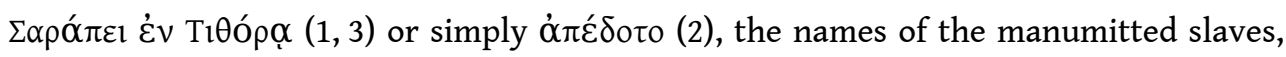
the price, the conditions of manumission, and the names of witnesses and guarantors; in case of violation, a fine was payable to the sanctuary of Sarapis (1-3). Copies of the

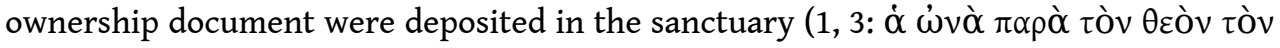

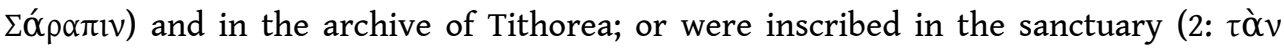

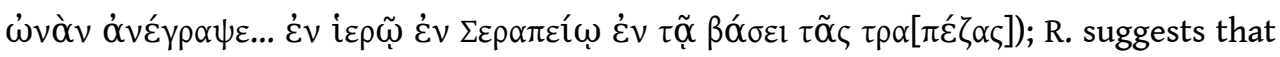

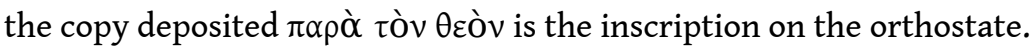

160) A.S. RuSJaEVA, Graffiti Ol'vii Pontijskoj, Simferopol, 2010 [BE 2011, 454]: R. presents a catalogue of ca. 800 graffiti from Olbia, half of which are inedita, mostly consisting of a few letters. [Non vidimus. We present a selection of new texts based on the report of A. AVRAM, BE 2011, 454]. West Temenos (p. 42-101): Dedications to Achilles (148), Apollo Aiginaios (15), Apollo (23, 26-28), the Dioskouroi (112-121), Hermes (132-133), Meter

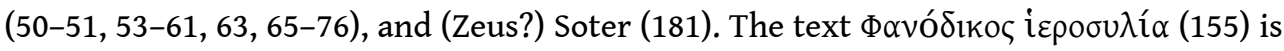
enigmatic [perhaps $\Phi \alpha v o ́ \delta ı к о \varsigma, ~ i \varepsilon p o \sigma u \lambda i ́ \alpha$ ('Phanodikos, because of sacrilege'). This graffito makes an accusation of some sort, but the context is unclear: a curse?, an oracular enquiry?, a message? It may be related to a lawsuit; cf. $n^{\circ} 180$ ( $\delta \kappa \alpha \sigma[\tau-~-]$ (Avram's reading)]. Upper town (p. 102-162): Dedications to Artemis (7), Demeter (21:

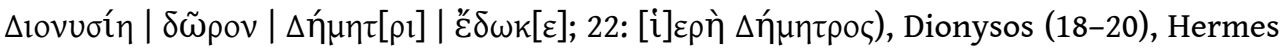
(27-30), Kore (11-12), Poseidon (14-15), and Zeus Soter (31). According to Avram n ${ }^{\circ} 34$ 


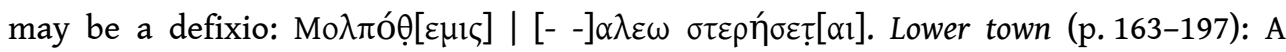
dedication to Artemis Ephesie.

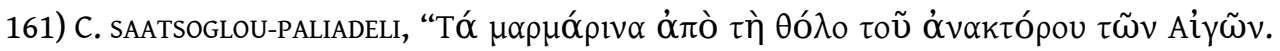

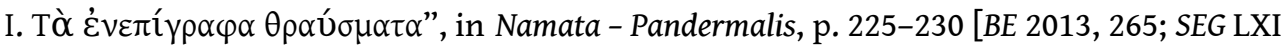
482/483]: The author publishes two similar dedications from a cult room of the palace of Aigai (Vergina). One of them had already been published and interpreted as a dedication made by the sons of King Perseus, who dedicated a statue of their father to Herakles Patroios (SEG XLVI 829; EBGR 1997, 166). The two marble monuments are pillar-shaped shafts, decorated on top with two anthemia and an Ionic kymation and in the body with a frieze of alternate bucrania and phialai. S.-P. presents a new restoration of the known inscription, according to which King Perseus dedicated a statue of his father, Philip V, to the ancestral god of the Temenids. The kings' names

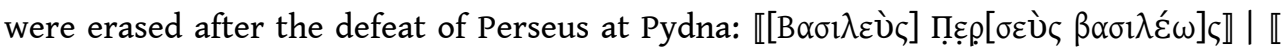

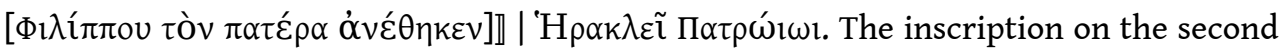

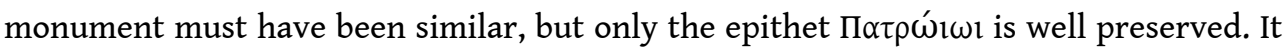

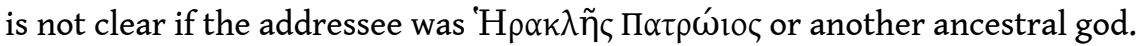

162) I. SALVO, "Sweet Revenge: Emotional Factors in 'Prayers for Justice", in Unveiling Emotions, p. 235-266: S. examines how the wish for revenge was channelled into cursing prayers. Her starting point is the plea for revenge in the Jewish epitaph of Heraklea from Rheneia (I.Délos 2532 I A-B, 2nd/1st cent.), which she discusses in great detail. Attributing Heraklea's untimely death to foul play, her relatives made public their desire for vengeance, addressing their prayer to God but also expecting it to be read by passers-by. S. analyses the various means by which the author expressed the sense of loss and affliction and attempted to persuade God to act (flattery of God, hope, urgency of the request, invocation of the God's omniscience and power; cf. SEG L 1233; I.Délos 2532 II). In similar texts from Alexandria (GV 1875, 2nd/1st cent.) [cf. EBGR 2002, 54] and Alexandria Troas (I.Alexandreia Troas 90) the wish for revenge was enhanced by presenting the text as the very emotional prayers of the victims themselves. The public expression of the desire for revenge was socially acceptable, and it can be found in many 'prayers for justice' (e.g. I.Délos 2531; I.Knidos 148, 150). The wish for revenge is characterized by a sense of violation and by feelings of helplessness that provoke action-orientated emotions. Such emotions were a kind of a 'social toxin', poisoning social and personal lives in a small community operating as a face-to-face society. By condensing retaliatory emotions into a text that was delivered to a divinity, the responsibility for action was transferred to the divinity. Thus, through a socially accepted ritual, the negative emotions were eradicated from everyday life. S. also comments on the importance of Schadenfreude in emotionally loaded curses (e.g. IG XII 7, p. 1 from Amorgos; SB 1323). Prayers for justice and the public expression of one's emotions served to regulate social behavior and interactions, keeping under control the negative emotions that could threaten a peaceful life in a community.

163) I. SALVo, "Ristabilimento della pace civica e riti di purificazione a Dikaia", ASNSP Ser. 5, 4, 1 (2012), p. 89-102: A dossier of documents concerning the reconciliation of the citizens of Dikaia after a civil war in 364 BCE (EBGR 2008, 156-157; SEG LVII 576) contains an oath and details of a ritual of purification. S. summarizes the content of the inscription, discusses the historical context (a civil war), and comments on the ritual of purification. 


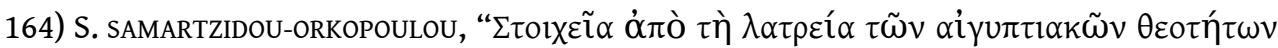

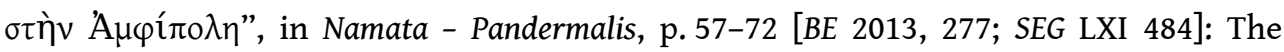
author discusses archaeological evidence for the cult of the Egyptian gods in Amphipolis, focusing on a statue of Sarapis. She summarizes the epigraphic evidence for the cult of Sarapis in this city (RICIS 113/0901-113/0910 and two unpublished inscriptions that mention Avoũ $\beta 1 \zeta)$. The archaeological evidence suggests the existence of three sanctuaries of the Egyptian gods: a sanctuary in the northwest part of the city was founded in the 3rd cent.; a second sanctuary in the citadel was founded in the Imperial period; a third, rural sanctuary, where Egyptian and Anatolian deities were jointly worshipped, seems to have been established in the Hellenistic period outside of the east wall.

165) C. SÁNCHEZ-NATALÍAS, “Fistus difloiscat languat... Re-Reading of Defixio Bologna 2", ZPE 181 (2012), p. 140-148: The author republishes a defixio in the Museo Archeologico Civico di Bologna (4th/5th cent.), published by A. Olivieri in 1899 together with another four curse tablets of unknown provenance ("Tavolette plumbee bolognesi di defixiones", Studi Italiani di Filologia Classica 7 [1899], p. 193-198) [for the other three tablets see EBGR 2011, 112]. A drawing shows a standing naked figure with crossed (tied?) hands. A star is engraved on the genital area. Three winding snakes emerge from each side of the crowned head. Magical words and signs are inscribed on and on both sides of the figure in Greek ( $\varphi \omega \rho \beta \eta, \varphi \omega \rho \beta \varepsilon v, \varphi \omega \rho \beta \varepsilon o \mu \varphi \omega \rho \beta$, etc.). S.-N. identifies the figure as the invoked demonic power. The curse, written in Latin, is directed against Fistus, probably a senator (sinator); magical powers are asked to destroy the victim ('crush, kill Fistus the senator; crush, kill Fistus; crush... Fistus, the senator; crush, kill Fistus the senator. May Fistus dilute, languish, sink and may all his limbs dissolve, all his entrails, of Fistus. Dissolve his limbs and entrails, may he languish. Burst his veins, break all his limbs. Fistus the senator').

166) S. SAPRYKIN, N. FEDOSEEV, "New Lead Plaques with Greek Inscriptions from East Crimea (Bosporos)", in Onomatologos, p. 422-434 [BE 2009, 384; 2011, 463; SEG LVIII]: Ed. pr. of a curse tablet found on the acropolis of Pantikapaion (ca. 300-250). Only remains of personal names can be recognized and possibly remains of a verb ([₹z] $\theta \varepsilon \lambda \varepsilon v$ ?). For a Russian version see VDI 266, 3 (2008), p. 64-72.

167) I. SAVALLi-LESTRADE, "Intitulés royaux et intitulés civiques dans les inscriptions de cités sujettes de Carie et de Lycie (Amyzon, Eurômos, Xanthos). Histoire politique et mutations institutionelles", Studi Ellenistici 24 (2010), p. 127-148: [SEG LX 1083-1084, 1101]: S.-L. discusses how the dating formulas used in cities of Karia and Lykia reflect their changing relations to Hellenistic kings, the level of subordination of the cities, and local identities [cf. on the same subject I. SAVALLI-LESTRADE, "Les rois hellénistiques, maitres du temps", in Des rois au Prince, p. 55-83]. Such changes include the introduction of the Macedonian calendar in Amyzon (cf. I.Amyzon 3, 14, 15, 28 and 36); the use of the high-priest of the royal cult and the high-priest of Zeus Kretagenes and Diktynna (I.Amyzon 14) as eponymous magistrates in Amyzon and that of the priest of the kings as an eponymous magistrate in Amyzon (I.Amyzon 14-15), Mylasa (I.Mylasa 894), and Xanthos (SEG XLVI 1721). This priesthood, possibly modelled after the central priesthood in the Seleucid kingdom, may not be a specifically Seleucid phenomenon but may also have existed already during the Ptolemaic rule in Lykia (Xanthos). In this study, S.-L. also discusses a regulation from Euromos concerning the introduction of new magistracies shortly after 197 BCE (SEG XLIII 707; p. 136-148). In view of the 
introduction of the board of the kosmoi, a Cretan institution, and the fact that the priest of Zeus Kretagenetas served as $\sigma \tau \varepsilon \varphi \alpha \vee \eta \varphi$ ó $о \zeta$, S.-L. adopts a suggestion by T. BOULAY (in his thesis Les cités grecques et la guerre en Asie Mineure hellénistique) that Cretan mercenaries, living in the area of Myous, may have settled in Philippoi-Euromos [see now T. BOUlay, Arès dans la cité. Les poleis et la guerre dans l'Asie Mineure hellénistique, Pisa, 2014, p. 326f.].

168) A.C. SCAFURo, "Conservative Trends in Athenian Law: IE 138, a Law Concerning the Mysteries", in Symposion 2009, p. 23-46 [BE 2011, 228]: S. studies the law concerning the Eleusinian mysteries (I.Eleusis 138, ca. 367-347 BCE) in connection with other regulations concerning the mysteries (I.Eleusis $7,13,19,21,22,28 \mathrm{a} / \mathrm{b}, 30,237,250$ ) and literary sources (Andocides I, 111 and 115f; Demosthenes XXI, 175). She stresses the competence of the proposers of laws and decrees in producing rational, coherent and comprehensive regulations (esp. I.Eleusis 19 and 138).

169) N. SEKUNDA, "Kaineus", in Onomatologos, p. 344-354 [BE 2011, 377; SEG LX 580]: S.

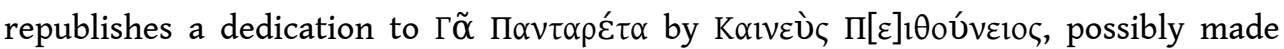
after a visit to Delphi (IG IX 2, 491; ca. 325-150) and a proxeny decree (SEG XXIX 502), which mentions a homonymous tagos. Kaineus is the name of a Lapith, the son of Atrax. Because of the significance of this hero for the city of Atrax and the fact that the personal name Kaıvé $\varsigma$ is not attested in any other Thessalian city, S. attributes to Atrax other homonymous men mentioned in ancient sources.

411 170) M. SÈvE, "Le dossier épigraphique du sculpteur Damophon de Messène", Ktema 33 (2008), p. 117-134: S. presents a list of the inscriptions concerning the sculptor Damophon (late 3rd/early 2nd cent.) and his family, republishing the text of those inscriptions that have been published (decrees of Lykosoura, Leukas, Kranioi, Kythnos, and Oiantheia: IG IX ${ }^{2}$ 1, 1475, 1583; SEG XLIX 423; XLI 332; LIV 452; honorific inscriptions for and dedications by family members: IG V 2, 454, 540; SEG XXIII 219; XLI 349, 350, 352). Two decrees from Melos and Gerenia are still unpublished. This dossier includes decrees of Lykosoura and Leukas honoring the sculptor for waiving payments for the construction of statues of Despoina (SEG XLI 332) and Aphrodite Limenarchis (IG IX ${ }^{2} 1$, 1475). Some of the inscriptions mention the dedication of sculptural decoration and statues (statue of Hagemon: SEG XLI 352; the akroteria of the temple of Zeus: SEG LII 415; statues dedicated to the Goddesses in Lykosoura: IG V 2, 539; dedication to Poseidon Asphaleios in Megalopolis by family members: IG V 2, 454).

412 171) N. SHARANKOV, "Language and Society in Roman Thrace", in Early Roman Thrace, p.135-155: In a study dedicated to the linguistic situation in Thrace in the Imperial period, S. presents the ed.pr. of a votive relief with the representation of Hermes with kerykeion and a three-faced Hekate (Jagodovo, Imperial period; p. 137f.). The Thracian

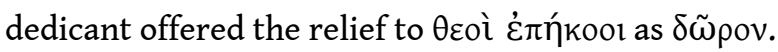

413 172) J.L. SHEAR, "Religion and the Polis. The Cult of the Tyrannicides at Athens", Kernos 25 (2012), p. 27-55: S. plausibly argues that the cult of the tyrannicides was established in Athens in the late 6th cent. (probably as early as $507 \mathrm{BCE}$ ), in order to promote a particular version of the overthrow of the Peisistratids. The cult was celebrated annually at the Panathenaia, which was the anniversary of their attempt on the life of

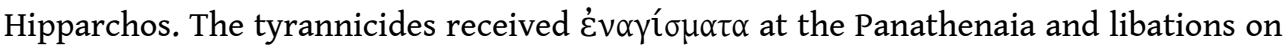
the occasion of other sacrifices. S. studies in detail the importance of this cult for the public image of the Athenians. 
414 173) J.L. SHEAR, "Hadrian, the Panathenaia, and the Athenian Calendar", ZPE 180 (2012), p. 159-172: It is widely believed that in the Imperial period the Great Panathenaia were celebrated in the fourth year of the Olympic cycle. S. argues that they continued to be celebrated in the third year. The re-organization of the sequence of agonistic festivals by Hadrian favored the Athenian festivals by placing the Hadrianeia in the first year of the Olympic cycle, the Pantathenaia in the third, and the Panhellenia in the fourth. S.'s hypothesis, if correct, has important consequences for the chronology of agonistic inscriptions; it means, e.g., that the naumachia held under the responsibility of Herennios Dexippos (IG II 2245 lines 477f.) cannot have been part of the Panathenaia.

174) W.J. SLATER, "Paying the Pipers", in B. LE GUEN (ed.), L'argent dans les concours du monde grec, Saint Denis, 2010, p. 249-281 [SEG LX 1911]: S. gives an overview of the different kinds of pay and rewards given to actors, choruses, and musicians, who performed in festivals (salaries, food provisions, prizes), as well as the fines imposed for non-fulfillment of their obligations. He discusses in detail the evidence provided by inscriptions concerning the Dionysia and Demetrieia in Chalkis (IG XII 9, 207), the Asklapieia and Apollonia in Epidauros (IG IV $\left.{ }^{2} 1,99\right)$, the Mouseia in Thespiai (I.Thespiai $152,153,156,157,161,163)$, and the Sarapieia of Tanagra (SEG XIX 335).

175) E. SOLER, "Les initiations de l'aristocratie sénatoriale païenne de Rome, au IV siècle d'après les inscriptions", in C. DEROUX (ed.), Corolla Epigraphica. Hommages au professeur Yves Burnand, Brussels, 2011, II, p. 671-682: A group of inscriptions, mainly from Rome and Ostia, attest the multiple initiation of members of the senatorial aristocracy in mystery cults (ca. 360-380). A well-known example is that of Vettius Agorius Praetextatus, who was initiated in the mysteries of Dionysos, Eleusis, Kybele and Attis, and Mithras (CIL VI 1779) and also served as curialis Herculis; Herakles was important in the theology of the Neoplatonics, and his descent into the underworld was associated with the Eleusinian mysteries. Praetextatus' wife was initiated in the mysteries of Eleusis, Dionysos, Demeter and Kore in Lerna, the goddesses of Aigina, the Egyptian mysteries, the cult of Hekate, and the mysteries of Mithras. Alfenius Ceionius Iulianus Kamenius was initiated in mysteries of Mithras, Hekate, and Dionysos (CIL VI 1675). Ulpius Egnatius Fauentius was initiated in the mysteries of Kybele and Attis, Mithras, Dionysos, Hekate, and Isis (CIL VI 511; for other multiple initiations see CIL VI 500, 510, 512, 30966; An.Ép. 1955, n 180). Similar multiple initiations are known for the Emperor Julian and his circle (Libanios, Or. XIV, 5; XIV, 7; XIV, 65). S. associates this trend with the interest in Neoplatonic theurgy [for individuals in Julian's circle who were interested in initiations, one may add Plutarch, appointed by Julian as governor of the provincia Insularum and initiated in the mysteries of Zeus Idaios; see IG XII 6, 584 II and SEG LIV 808].

417 176) G. STAAB, "Hellenistisches Gedicht auf ein verstorbenes Mädchen aus dem Gebiet von Priene", EA 45 (2012), p. 47-54: Ed. pr. of a Hellenistic epigram from the vicinity of Priene. The epigram presents the deceased girl speaking from her grave and reporting that the Fates forced her to come to a temenos of the Nymphs. G. proposes the

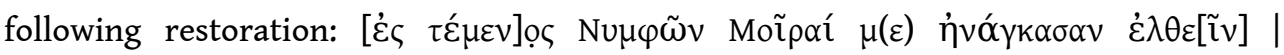

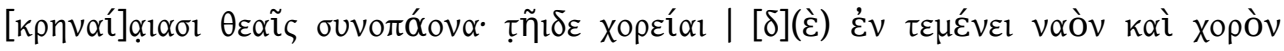

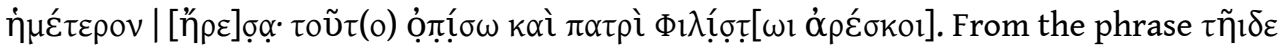

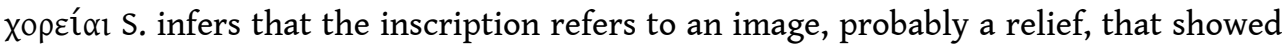
the girl dancing together with the Nymphs. He suspects that the image was placed in a sanctuary of the Nymphs as a memorial for the girl, who had probably drowned ('The 
fates forced me to come to the precinct of the Nymphs, as a companion of the goddesses of the water sources. With this dance performance I gave delight in the precinct to the temple and our chorus; may also my father Philistos find delight in this later'). [S.'s restoration is based on the assumption that the 3rd verse is a pentameter beginning with $\delta \varepsilon$ and that, consequently, this line was shorter than lines 1-2. But as one can see on the photo, line 3 is longer than lines 1-2, and S.'s assumption that there were vacats at the beginning of lines 3-4 disturbs the centered arrangement of the text

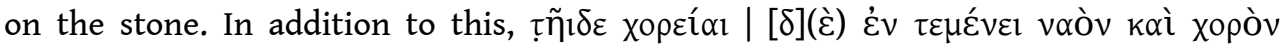

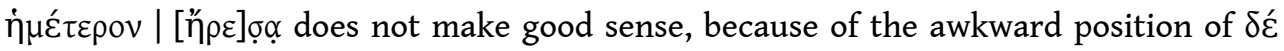

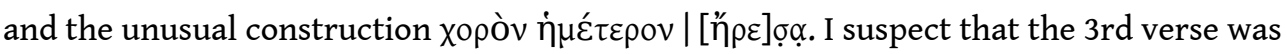
a hexameter].

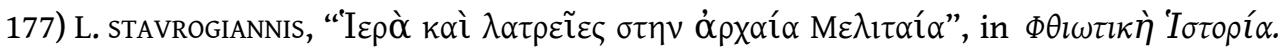

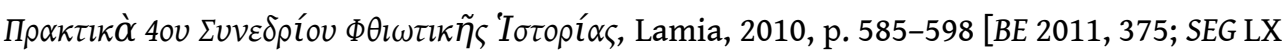
595-596]: S. gives an overview of the cults in Melitaia (Aspalis, Artemis, Asklepios, Boras, Demeter, Ennodia, Hermes, Ino, Poseidon, Zeus, and Zeus Soterios). He presents the ed.pr. of a senatus consultum concerning a dispute over the ownership of public

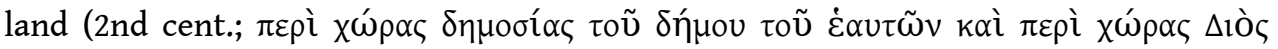

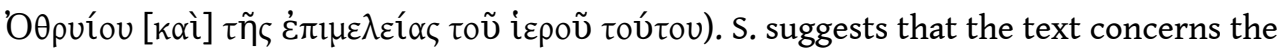
well-known dispute between Melitaia and Narthakion over the ownership of land (IG IX 2, 89; Ager, Arbitration $\mathrm{n}^{\text {os }} 32,79,154$, and 156). [In my comments in SEG LX 596 I explain why this cannot be the case. The new text treats three different issues: the ownership

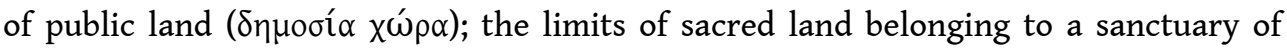

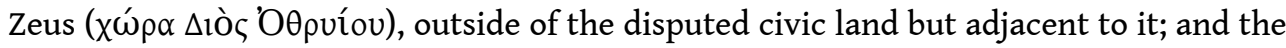
control ( $\dot{\varepsilon} \pi \mu \varepsilon \dot{\lambda \varepsilon l \alpha)}$ of the sanctuary. The status of the land and sanctuary of Zeus Othryios, as an extra-urban sanctuary in the mountainous borderland between two

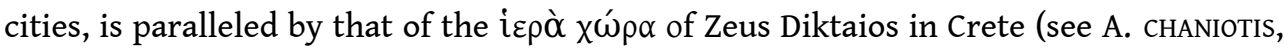
"Extra-urban Sanctuaries in Classical and Hellenistic Crete", in G. DELIGIANNAKIS, Y. GALANAKIS (eds.), The Aegean and its Cultures, Oxford, 2009, p. 59-67)]. The inscription was found on the hill of Agios Georgios, where the main sanctuary of Melitaia was located S. identifies the sanctuary as that of Zeus Othryios. [R. BоUсноN, BE 2011, 375, objects that the sanctuary of a god of mountain peaks cannot be located on the hill of Agios Georgios; the sanctuary where the block was found, close to the citadel of Melitaia, was the sanctuary where public documents were published (cf. IG IX 2, 206/207).

178) A. STYLow, "Stumm wie ein Frosch ohne Zunge! Eine neue Fluchtafel aus Celti (Peñaflor, Prov. Sevilla)", ZPE 181 (2012), p. 149-155: Ed. pr. of a lead curse tablet from Celti (Spain, late 1st cent. CE). The curse concerns a lawsuit: 'May Valerius Marcellus be dumb and silent in the lawsuit, which he has against C. Licinius Gallus. Exactly as a frog without tongue is dumb and silent (quemadmodum rana sene lingua muta tacita est), thus may also Valerius Marcellus be dumb and silent and incapable (of action) (mutus, tacitus, debilitatus) against Licinius Gallus'. S. comments on the fact that the defigens states his name. This is the first reference to a frog in a defixio, in the similia similibus-formula. In an appendix, S. gives a list of the defixiones found in Spain.

179) V.M. SтRоскA, "Bauphasen des kaiserzeitlichen Asklepieions von Pergamon", MDAIII) 62 (2012), p. 199-287: A close study of the inscriptions and the architectural ornaments from the Asklepieion of Pergamon shows that, contrary to the communis opinio, this sanctuary was not built as one single building project under Hadrian; its construction lasted from ca. 90 to ca. $160 \mathrm{CE}$. S. discusses the inscriptions that concern 
the construction of the stoa of the gymnasion of the neoi (I.Pergamon 461), the dedicatory inscription of the 'Kaisersaal' (H. HEPDING, "Die Arbeiten zu Pergamon I: Die Inschriften", MDAI(A) 32 [1907], p. 347f. $n^{\circ}$ 99), the dedicatory inscription of the north portico (AvPergamon VIII $3 \mathrm{n}^{\circ} 64$; new reconstruction). In an appendix, M. WÖRRLE (p. 272-275) presents the ed.pr. of a dedication to the Theoi Sebastoi and the demos of Pergamon: T. Iulius Amyntas Klaudianos and his wife dedicated two seating blocks in the theater, after serving as high priests of Asia (ca. $100 \mathrm{CE}$ ).

180) D. summA, "Una nuova lista cultuale per Artemide", in Lo spazio ionico, p. 385-393 [SEG LX 547/548]: D. recognizes a fragmentary inscription from Palairos (IG IX ${ }^{2} 1,451$, 2nd cent.) as a list of priests who made a dedication to Artemis [cf. supra $\mathrm{n}^{\circ} 15$ ] in

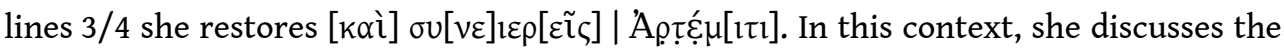

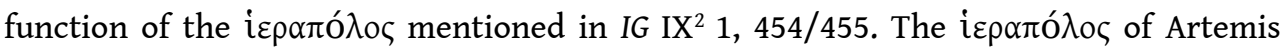
served as an annual eponymous magistrate for activities related to the sanctuary of

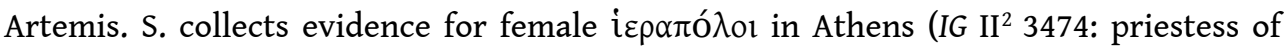
Athena), Megalopolis (IG V 2, 461: priestess of Aphrodite), and Argos (SEG XI 304:

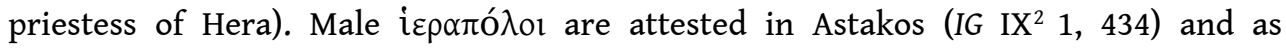
eponymous officials in Sicily.

181) H. TAEUBER, "Inschriften aus dem Vediusgymnasium. Die Neufunde", in M. STESKAL, M. LA TORRE (eds.), Das Vediusgymnasium in Ephesos (Forschungen in Ephesos XIV.1), Vienna, 2008, p. 243-252 [BE 2009, 28; SEG LVIII 1309-1325]: Ed. pr. of new inscriptions from the gymnasium of Vedius in Ephesos (Imperial period). They include a graffito on a marble plaque with an acclamation of Artemis (I 5B = SEG LVIII 1312 B: 'E $\varphi \varepsilon \sigma i ́ \alpha)$ and an honorific inscription for a man who served as agonothetes of the Megala Olympia, a contest established during Hadrian's reign (I $72=$ SEG LVIII 1315).

182) C. TANRIVER, "The Cult of Theos Peismatene in Mysia", EA 45 (2012), p. 93-99 [BE 2013, 352]: The cult of Theos Peismatene was known from an inscription of unknown provenance (EBGR 2006, 53; SEG LVI 2042). T. presents the ed.pr. of 12 relief stele dedicated to this goddess, all kept in a private collection and allegedly found near Daskyleion in Mysia; the sanctuary of this goddess must have been located near the villages Yeşilçomlu and Doğa. The goddess is represented on a throne flanked by two dogs; she wears a polos and holds an object (a tympanon?) in her left hand; with the right hand she makes a libation on an altar, in front of a tree, in the presence of worshippers. The dedications were made by both men and women in fulfillment of vows (1-8, 10-11: عủxńv), in one case as an expression of gratitude for the goddess' help in saving a woman (9: $\sigma \omega \theta \varepsilon \tilde{\tau} \sigma \alpha \chi \alpha \rho[\sigma \tau \eta ́ p l o v])$. In three cases, the vows were made for the well-being of the dedicants and family members $(2-3,5)$. One stele $(12)$ is uninscribed (or the inscription is not preserved).

183) R. тЕKоĞLU, “Two Inscriptions from Arcik", MDAI(I) 60 (2010), p. 110-111 [BE 2011, 265; 2012, 28 and 390; SEG LX 1570-1571]: Ed. pr. of two inscriptions from the area of Xanthos. The first inscription honors M. Aurelius Tlepolemos, a Roman knight (ca. 200

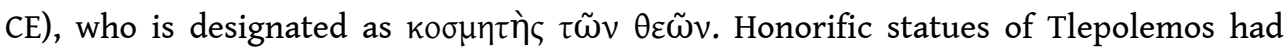
been erected in the sanctuaries and the temples of the city and in the temple of Leto

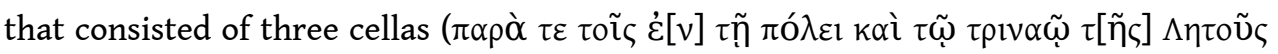

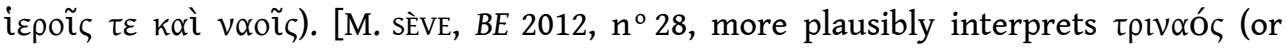

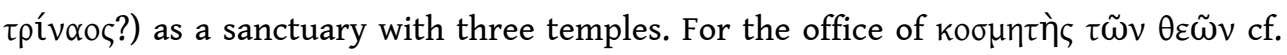

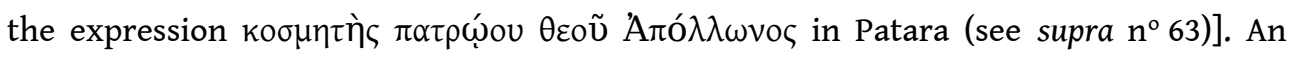


additional statue was to be erected near a temple. The same Tlepolemos is mentioned in a second inscription as the recipient of a dedication of statues: $B \alpha \sigma \imath \lambda \varepsilon 1[--$ - ]ov [- - - ]

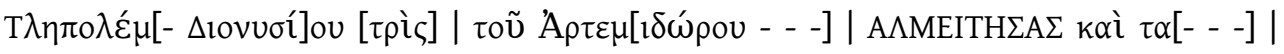

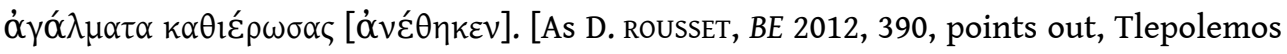
is the dedicant, making a dedication to $\mathrm{B} \alpha \sigma \imath \lambda \varepsilon[[--]]$.

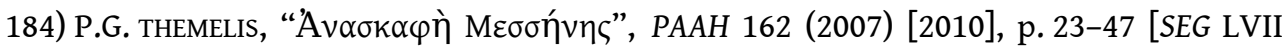
369-370, 373-376]: T.'s report on the results of the excavation in Messene contains references to several new inscriptions. A fragmentary decree of the Pylians in honor of Archedamos (late 1st cent., p. 42) has been presented in EBGR 2011, 12. A fragmentary inscription records the dedication of the proskenion of the theater to Trajan by

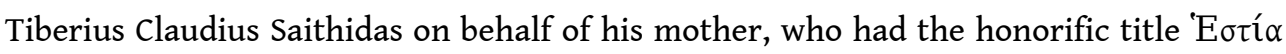
$\pi 0 ́ \lambda \varepsilon \omega \varsigma$ (p. 28f.). An honorific statue for the high priest Tiberius Claudius Geminianos was erected when his brothers served as priest of Zeus Ithomatas and secretary respectively (p. 29-31, ca. 140-170). Other inscriptions include a dedication to Dionysos by Diouskouridas (3rd cent., p. 26), possibly a man who is known as agonothetes (SEG XLI 365), a dedication to Eleithyia (ca. 200, p. 45f.), and stamped tiles mentioning Artemis in the genitive (p. 28).

185) P. THEMELIS, "The Cult of Isis at Ancient Messene", in Bibliotheca Isiaca II, p. 97-109: The cult of Isis in Messene is mentioned by Pausanias (IV, 32, 6) and attested through archaeological finds (mainly statuary). The sanctuary, of which a crypt is preserved, has been identified near the theater. The finds include an enigmatic inscription on a trapezoid capital found re-used in a Byzantine basilica (SEG LI 491; EBGR 2004, 268). T. assumes that it was originally part of a door-jam of the theater's scaenae frons. The text reads

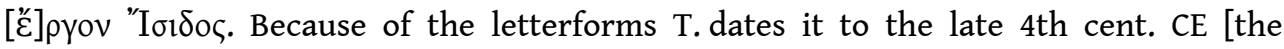
writing is careless; it is a graffito that can be earlier (2nd/3rd cent.). T. does not attempt an interpretation. 'Epyov may have the meaning 'miracle' as in Isyllos' hymn for Asklepios:

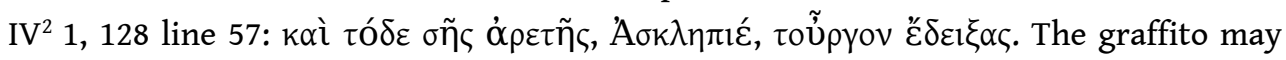
refer to a painted representation of a miracle on display in the theater].

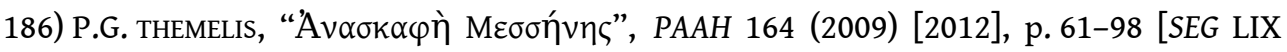
$411,416,417,420,422,423,427]$ : Ed. pr. of inscriptions found during recent excavations in Messene. The most important text is an agonistic inscription of the late 1st cent. BCE or early 1st cent. CE, which had already been presented in earlier reports (see SEG XLIII 162; p. 71-74). The inscription lists victories of an athlete in wrestling and pankration in a series of agonistic festivals, including two contests for which this inscription was, until recently, the only evidence: the Delia in Tanagra [now attested in SEG LVII 452], and the Rhomaia in Aigion [now attested in SEG LIX 492]. The other victories were won at the following contests: Aleiaia, Eleutheria in Larisa and in Plataiai, Halieia in Rhodes, Heraia, Isthmia, Lykaia, Nemea, Olympia, Panathenaia, Pythia, Pythia in Megara, and Rhomaia in Chalkis and in Messene. Other agonistic inscriptions record the victory of a boy pankratiast at the Aleaia (p. 76) and the victories of a boy boxer at the Basileia of Lebadeia and the Pythia (p. 69f., 2nd/1st cent.). Other inscriptions include a dedication to Artemis Soteira (93f., 2nd cent.) and Zeus Epidotas (95); both epithets are attested in Messene for the first time. Epidotas is an epithet of Zeus in Sparta (Hesychios, s.v.; Pausanias VIII, 9, 2) and in Mantineia (IG V 2, 270). A Roman officer made a dedication to Iuppiter Capitolinus (Zeus Kapitolios; p. 81-83, 1st/2nd cent. CE). A poorly preserved 
mosaic (2nd cent. CE, p. 78-81) still shows the labels that identify two mythological figures: Messene, the eponymous heroine and mythical queen of Messenia, and Attikos, possibly a son of Pandion (cf. Pausanias IV, 1, 6-8). Finally, the finds include two defixiones, found in the Thesauros south of the temple of Messene. T. suggests that the curse tablets were thrown into the Thesauros after the murder of Philopoimen in 183 BCE. He presents the text of one of them. The defigens invokes ( $\kappa \alpha \lambda \tilde{\omega})$ chthonic deities

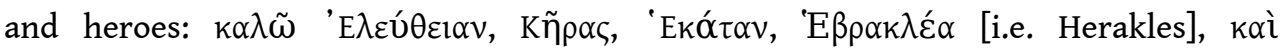

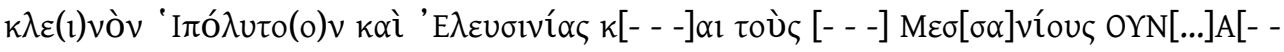

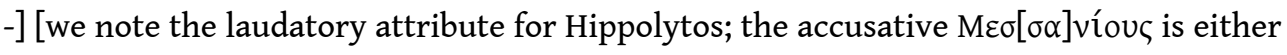
an attribute of Messenian gods or more likely not the object of $\kappa \alpha \lambda \tilde{\omega}$ but of an infinitive that describes the action that the defigens requests (cf. the ending [- - - $\alpha$ l)].

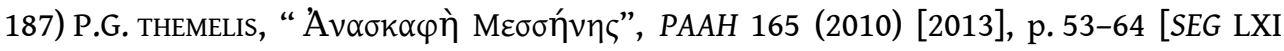
443]: Ed. pr. of an inscription that records the dedication of the statue of a former thoinarmostria to Demeter and Kore (Messene, Hellenistic, p. $64 \mathrm{n}^{\circ} 3$ ); the office is attested in the Peloponnese (e.g. IG V 1, 1390, 1447, 1498; SEG XXV 437).

188) P tHONEMANN “The Women of Akmoneia", JRS 100 (2010), p. 163-178 [BE 2011, 571; SEG LX 1423]: Ed. pr. of an honorific inscription from Akmonia (6/7 CE). The corporate body of 'the Greek and Roman wives' of Akmoneia honored a high priestess.

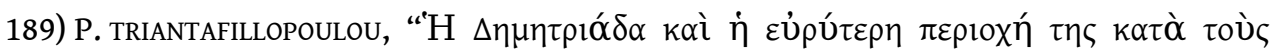

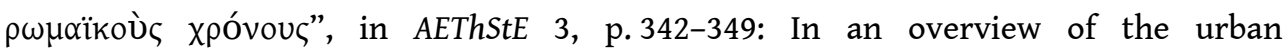
development of Demetrias after the Roman conquest, T. mentions a relief stele, decorated with an ear and dedicated to Meter Theon (Demetrias, Imperial period). She also mentions statuettes of Zeus, Hermes, Athena, and Aphrodite found in domestic contexts.

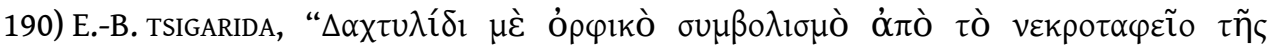

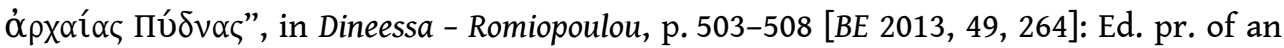
inscribed silver ring found in the grave of a woman in Pydna (late 4th cent.). The inscription, with gold inlayed letters, names the ring's original owner (Menandros, son of Nikon). Later, a gold crescent was fixed to the bezel, covering one letter of the inscription. A similar inlayed crescent is found on a ring from Cyprus (F.H. MARSHALL, Catalogue of the Finger Rings, Greek, Etruscan, and Roman, in the Departments of Antiquities, British Museum, London, 1968, $\mathrm{n}^{\circ}$ 1057). T. associates the crescent, a symbol connected with Selene, with Orphic views and speculates that the woman was an initiate into the Orphic mysteries.

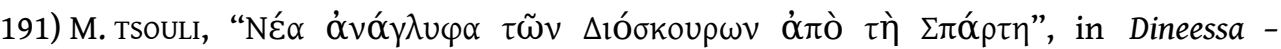
Romiopoulou, p. 409-418 [BE 2013, 38]: Publication of two dedicatory reliefs from Sparta depicting the Dioskouroi (1st cent. BCE/CE). One of the reliefs, made of clay, has an unusual iconography: right and left, the Dioskouroi are represented standing next to their horses; in the middle, two women flank an altar. They must be the Leukippids, i.e. the Messenian princesses abducted by the Dioskouroi. An inscription ("E $\rho \omega \tau$ o[ $\zeta]$ ) written above the altar suggests that the Dioskouroi and their wives are offering a sacrifice on the altar of Eros, possibly in a wedding scene.

192) A. TWARDECKI, "A Collegium of Hieroi in the Bosporan Kingdom", in Pontika 2008, p. 371-376: T. discusses a grave epigram from the vicinity of Pantikapaion (CIRB 121; GV 1812, late 1st cent.), which has been interpreted as the epitaph of an Orphic (E. BIKERMAN, "The Orphic Blessing", Journal of the Warburg Institute 2 [1938], p. 368-374; cf. 
G. CASADIO, "Le metempsicosi tra Orfeo e Pitagora", in P. BORGEAUD [ed.], Orphisme et Orphée, Geneva, 1991, p. 136f.) or a philosopher (A.D. NOCK, "Orphism or Popular Philosophy?", HThR 33 [1940], p. 301-315; cf. D.V. PANCHENKO, "Epitaph of Hekataios (CIRB 121): Faith, Philosophical Topos or Choice of the Way?", in A.K. GAVRILOV [ed.], Studies in the History and Culture of Northern Black Sea Coast in Antiquity, St. Petersburg,

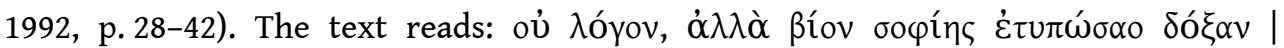

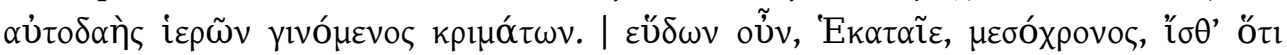

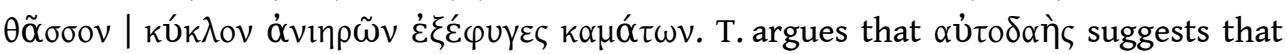
Hekataios 'was self-knowing or had self-knowledge from a god' (not self-taught or

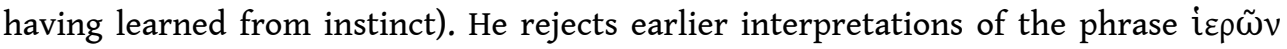

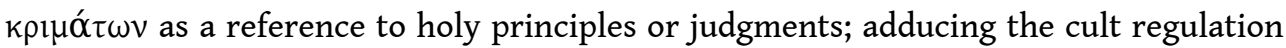

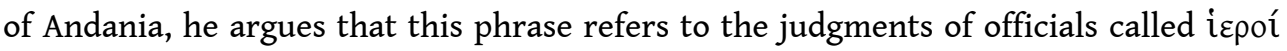

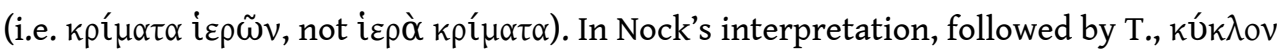
$\dot{\alpha} v i \eta \rho \tilde{\omega} \nu \dot{\varepsilon}^{\xi} \dot{\varepsilon} \varphi v \gamma \varepsilon \varsigma \kappa \alpha \mu \alpha \dot{\alpha} \tau \omega \nu$ is not a reference to escape from re-incarnation, but to escape from the daily troubles of life; Hekataios died middle-aged ( $\mu \varepsilon \sigma o ́ x \rho \circ v o \varsigma$ ), thus escaping from the pains of life faster than other people. T.offers the following translation: 'not by words, but by life you copied wisdom's glory, self-knowing you made judgments of holies. So resting, Hekataios, in the middle of time, know that faster you escaped wheel of grievous troubles' [sic! The idea of re-incarnation should, indeed, be put to rest. But a comparison with the cult regulation of Andania and the judiciary

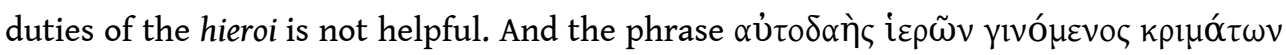
cannot be made to mean that Hekataios gave judgments as a hieros].

193) A. TZIAfAlias, B. Helly, "Inscriptions de la Tripolis de Perrhébie”, Studi Ellenistici 24 (2010) [2011], p. 71-125 [BE 2011, 399; SEG LX 586]: Ed. pr. of a dossier of letters sent by King Antigonos Doson to the Tripolitans in Thessaly. The documents concern privileges granted to soldiers and officers who fought at the battle of Selasia (222 BCE; 104-117 $\mathrm{n}^{\circ}$ IV). The pillar with the inscriptions was dedicated to Apollo Pythios and was found in the sanctuary of this god in Azoros.

194) A. TZIAFALIAS, G. LUCAS, "L'organisation de la surveillance du territoire de Dolichè", in AEThStE 3, p. 487-494: Ed. pr. of a fragmentary inscription that deals with the protection of the territory of Doliche (Thessaly, late 2nd cent.). The text mentions the months Apollonios (line 9), Hippodromios (line 23), and Itonios (line 26). Two

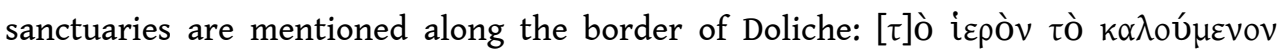
$\pi \alpha \lambda \alpha$ lóv (line 39) and the sanctuary of Themis (line 42).

195) G. VAlARINo, "Le epigrafi dello Hephaisteion e il culto di Efesto ad Atene", in Omaggio-Lombardi, p. 61-74: It is generally assumed that the construction of the temple of Hephaistos in Athens started in ca. 460 BCE and was completed 40 years later. V. challenges this view using the evidence provided by the accounts for the construction of cult statues (IG $\mathrm{I}^{3} 472$, ca. 421-419), the decree concerning the reorganization of the Hephasteia ( $I G \mathrm{I}^{3} 82$ ), and masons' marks. He argues that the construction started around 460-458 BCE and was completed a few years later; the statues were constructed in ca. 421-414 BCE; a torch-race was added in $420 \mathrm{BCE}$ to a pre-existing festival.

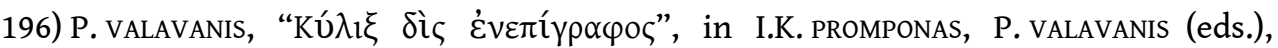

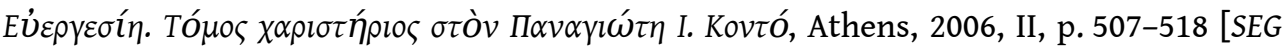
LXI 115 bis]: V. discusses an inscribed kylix from a cemetery in Marathon (CVA, Greece 7, 
$43 / 44, n^{\circ} \mathrm{K} 555$, ca. 500-475). The vase, decorated with a dancing maenad (interior) and Dionysos and Ariadne (exterior) was first inscribed with a graffito-dedication:

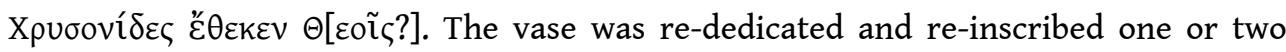

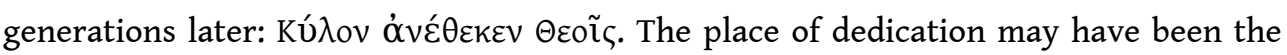
Delion of Marathon or the cave of Pan and the Nymphs at Oinoe. The two dedicatory inscriptions were erased when the kylix was deposited in a grave as an offering; to use a vase dedicated to gods as a grave offering was probably regarded as an offence.

197) R. VAN BREMEN, "Day and Night at Stratonikeia", in Labraunda and Karia, p. 149-157 [BE 2012, 27]: An enigmatic inscription from Stratonikeia (EBGR 2005, 30; SEG LV 1145) consists of a list of individuals, to whom 'a day and a night' were given. The entries

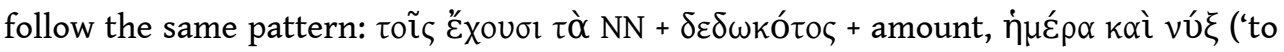
those, who hold the property of NN, son of NN + ethnic, who has given + amount, day and night + a numeral'). V.B. plausibly dates the inscription to the 1st cent. BCE (not the time of the Rhodian occupation of Karia in the early 2nd cent.) and rejects the view that the privilege was connected with a cult. It most likely granted the owners of certain properties the right to use a water reservoir on certain days, both day and night [cf. CIL XIV 3676, an inscription from Tibur assigning to individuals certain amounts of water in certain times ab hora noctis - ad horam -].

198) M. VEKSINA, "Zur Datierung der neuen Weihinschrift aus dem Oxos-Tempel", ZPE 181 (2012), p. 108-116: V. republishes the text of the dedication to the river-god Oxos (supra $\mathrm{n}^{\circ}$ 61; 'an den Oxos hat auf (göttliche) Anweisung IROMOIs (Sohn) des Nemiskos, MOLRPALRES, das sieben Talente schwere Bronzegefäß geweiht'). Based on the letterforms, V. proposes a date in the mid-2nd cent.

199) H.S. VERSNEL, Coping with the Gods. Wayward Readings in Greek Theology, Leiden, 2011: V.'s Sather Lectures are devoted to central aspects of the Greek concept of gods: the ways identities and properties were attributed to gods; how names and epithets contribute to the construction of a divine identity [for a nice example see supra $\mathrm{n}^{\circ}$ 82: two different epithets imply two different hypostases of Zeus]; how local, relatively isolated, pantheons co-existed [since local 'pantheons' continually evolve, I would prefer the term 'local cult constellations']; the central part played by the idea of justice in the perception of the divine; the development of the idea of the 'oneness' of god; the question of divine omnipotence, epiphanies, and miracles; and the Hellenistic ruler cult. By limiting this summary to the sections that heavily rely on the epigraphic evidence, I am not doing justice to a book that with plausible and innovative remarks and with an exhaustive collection and analysis of sources brings order to the Greek approaches to the divine, contextualizes the evidence, and addresses the contradictions and inconsistencies in the Greek concepts of god(s). The epigraphic evidence is exploited in the study of the acclamation ع $\tilde{i} \zeta \theta \varepsilon$ có (p. 280-283); the religious significance of aretalogies (p. 283-289); the main features of henotheism: cosmopolitan claims, miracles (arete), beatitude (makarismoi), acclamations of greatness, devotion, condemnation of impious behavior, recognition of the god's invincibility, divine punishment of the god's enemies, and public confession of guilt (p. 289-296); the religious significance of collections of healing miracles, especially of Asklepios (p. 400-

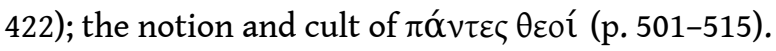

200) H.S. versnel, "Response to a Critique", in M. PIRANOMONTE, F. MARCo Simón (eds.), Contesti Magici - Contextos Magicos, Rome, 2012, p. 33-45: V. is engaged in a discussion with M. DREHER (supra $\mathrm{n}^{\circ} 59$ bis) concerning the existence of a separate category of 
defixiones, the 'prayers of justice'. Main characteristics of the 'prayers of justice' are the following: 1) the name of the author is mentioned; 2) an argument defending the action is presented, sometimes with a single term, sometimes with more elaborate details; 3 ) the author requests that the act be excused or that the writer be spared the possible adverse effects; 4) gods other than the usual chthonic deities appear; 5) either because of their superior character or as a persuasive gesture the gods are addressed either with a flattering adjective (e.g. phile) or with a superior title such as kyrios, kyria, or despoina; 6) expressions of supplication are added to personal and direct invocations of the deity; and 7) terms and names which refer to injustice and punishment are used. The existence of these features is denied by Dreher, who argues that similar features can also be found in traditional curses. In his response V. points out that he has always maintained that there are 'borderline curses' and an occasional overlap between the 'prayers for justice' and the other curses. In a detailed, point-to-point discussion of Dreher's arguments and relevant texts, V. shows that there are no traditional defixiones that contain references to injustice [see also supra $n^{\circ} 178$ ]. Similarly, he argues that the texts that are adduced by $\mathrm{D}$. as binding curses and display features attributed by V. to 'prayers for justice' are not 'pure' or ordinary defixiones but in fact 'prayers for justice'. There are no 'pure' curses that name the author, have references to injustice and revenge, use a different tone, or mention explicit grounds for cursing. V. re-iterates that beyond this distinction there is a 'mixed group'. [I have adopted and still use the notion of the 'prayer for justice' for most of the reasons stated by V., but also for an additional reason. As I argue in an article summarized in supra $\mathrm{n}^{\circ} 42$, there is an evolution of Greek attitudes towards rituals, from the belief that the efficacy of rituals depends on the mechanical performance of a prescribed action towards an emphasis on moral distinctions. I recognize the development of a new type of curses as part of this development].

201) R. VeYMiers, "Les cultes isiaques à Argos. Du mythe à l'archéologie", in Bibliotheca Isiaca II, p. 111-129: Because of the association of Io with Isis and Epaphos with Apis, the cult of the Egyptian gods in Argos has a specific character. V. discusses in detail the numismatic and archaeological evidence for the cult in Argos. The epigraphic evidence

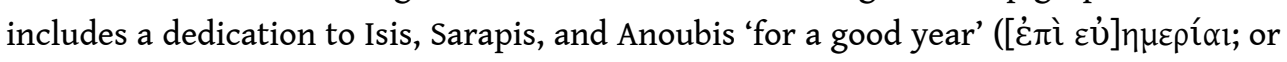

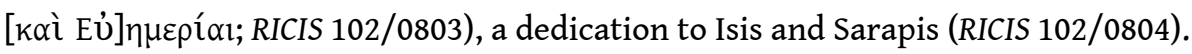

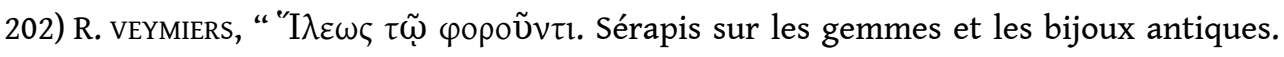
Supplément I", in Bibliotheca Isiaca II, p. 239-271: V. presents addenda to his catalogue of gems connected with the cult of Sarapis that we summarized in EBGR 2009, 171. We briefly present the inscriptions of religious content. Inedita are marked with an asterisk; we give references to those gems that are also included in A. MASTROCINQUE, Sylloge gemmarum gnosticarum II, Rome, 2008. The most common texts are acclamations

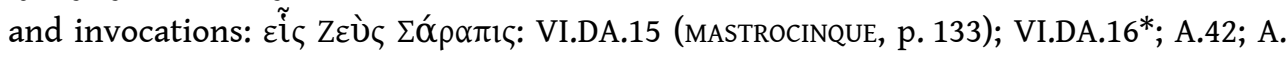

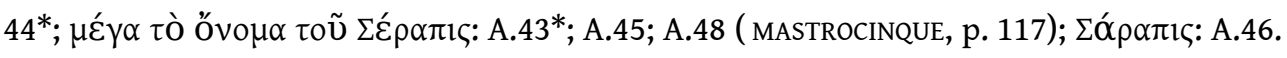
There are also two prayers ( $\Sigma \varepsilon \dot{\varepsilon} \rho \alpha \pi 1, \sigma \tilde{\omega} \zeta \varepsilon \mu \varepsilon:$ A.49*; $\varphi v ́ \lambda \alpha \xi \varepsilon:$ II.AB.27, obverse $=$ MASTROCINQUE, p. 188) and two gems with magical names and words $(A \beta p \alpha \sigma \alpha \xi ;$ I.H.6 = MASTROCINQUE, p. 43; magical words: II.AB.27, reverse = MASTROCINQUE, p. 188).

203) B. VIRGILIO, "L'epistola di reale dal santuario di Sinuri presso Mylasa in Caria, sulla base dei calci del Fonds Louis Robert della Académie des Inscriptions et Belles-Lettres", Studi Ellenistici 23 (2010), p. 55-107 [BE 2011, 530; SEG LX 1127]: Ed. pr. of an inscription found in 1934 by L. Robert in the sanctuary at Sinuri, near Mylasa. Only part of the 
inscription was quoted by L. ROBERT, Le Sanctuaire de Sinuri près de Mylasa. Première partie. Les inscriptions grecques, Paris, 1945, p. 12. According to V.'s readings and restorations, the inscription contains a letter sent by Antiochos III to the syngeneia that managed the sanctuary at Sinuri and to the priest. Antiochos promises the return of sacred slaves that had been carried away by his soldiers during his campaign in Karia in 203-201 BCE. 204) M. VITALE, Eparchie und Koinon in Kleinasien von der ausgehenden Republik bis ins 3. Jh. $n$. Chr. (Asia Minor Studien, 67), Bonn, 2012: V. examines the functions of the so-called 'provincial koina' in Asia Minor, highlighting the existence of smaller entities ('eparchies') that did not coincide with a province but had their own federal structure. The title of the highest official of these 'eparchies' was composed with the name of that region and the ending -arches (e.g. Asiarches, Lesbarches, Pontarches, Paphlagoniarches, Bithyniarches). V. examines the evidence for the koina of Asia, Phrygia - its existence is uncertain -, Galatia, Pontos, Bithynia, Pamphylia, Lykia, Kilikia, Kilikia-Isauria-Lykaonia, and Lykaonia. This study is relevant for the understanding of the imperial cult and its festivals in the Roman East, although V. does not specifically discuss this subject.

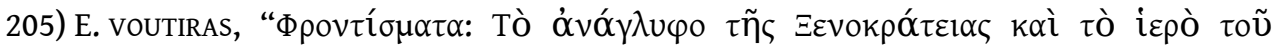

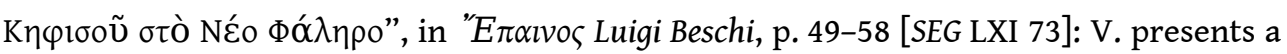
new interpretation of the relief dedicated by Xenokrateia in the sanctuary of the river god Kephisos (IG I ${ }^{3}$ 987, Athens, late 5th cent., probably after $413 \mathrm{BCE}$ ). In his interpretation, the dedicant presents her son to Kephisos, who is expected to look after

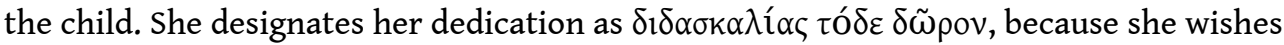
to thank the gods for their support in her efforts to educate her son.

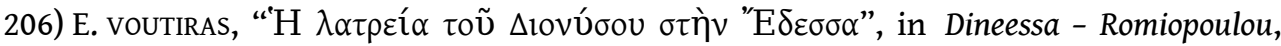
p. 563-568 [BE 2013, 271]: In Edessa, the cult of Dionysos is attested through coins and

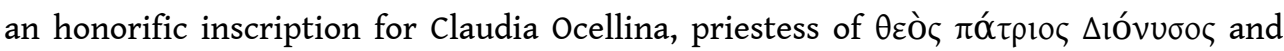

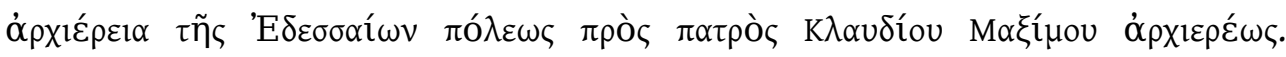

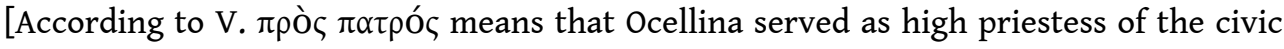

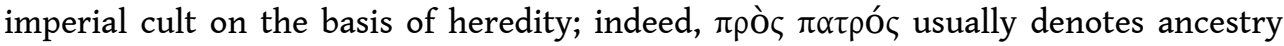

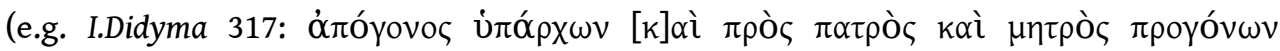

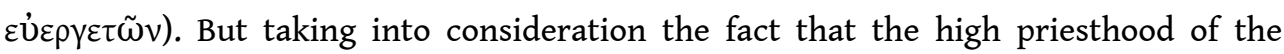
imperial cult was occupied by a man and his wife, and, in the case of widowers, by a man and his daughter, this expression may not refer to a hereditary priesthood (i.e.,

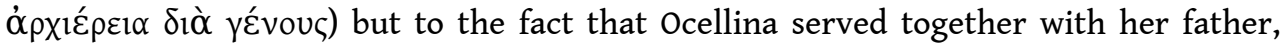
deriving her office $\pi \rho \grave{\zeta} \varsigma \pi \alpha \tau$ ò $\zeta$, i.e. 'from her father, on the side of the father'.] V. associates with Dionysos' cult a famous epigram for a pig that came to Edessa on foot from Dalmatia, wishing to see Emathia (Macedonia) and the cart of the phallus

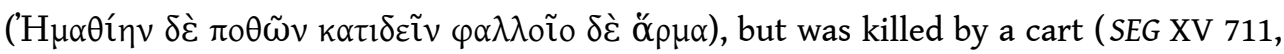
Edessa, 2nd/3rd cent.). The accident is depicted on a relief that shows a cart drawn by four mules and the pig under its wheels. V. plausibly assumes that the pig, which had been trained to perform in festivals, was killed by the cart used for the phallagogia in a festival of Dionysos; the relief shows the pole on which the phallus would be erected; the phallus itself, which was transported by the cart, is not shown, since it is covered. Acrobatic performances by pigs are attested (PETRONIUS, Satiricon 47, 9-10). V. collects evidence for phallic processions in Greece and Thessalonike. The latter are mentioned in an oration of Leo the Mathematician; V. LAURENT, "Une homélie inédite de l'archevêque de Thessalonique Léon le Philosophe sur l'Annonciation (25 mars 842)", in 
Mélanges Eugène Tisserant. II. Orient chrétien, Città del Vaticano 1964, p. 281-302). [A

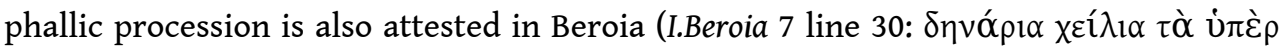

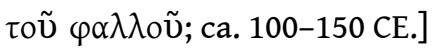

207) R. WAGMAN, "House of the Nymphs", in Studies Tracy, p. 323-325 [BE 2013, 230; SEG LX 600]: Republishes a dedicatory epigram from the cave of the Nymphs in Pharsalos

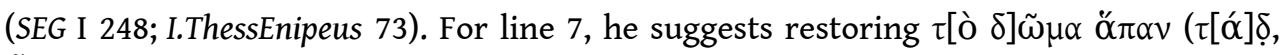
$\tilde{\omega} v \alpha$ חó $v$, earlier editors). The poem refers to a rudimentary architectural structure annexed to the cave.

208) J. WALLENSTEN, “Apollo and Artemis. Family Ties in Greek Dedicatory Language?”, in Current Approaches to Religion, p. 23-40: W. collects 17 joint dedications to Apollo and Artemis, sometimes also to other gods (87 of them from Delos); often, the two gods are also associated with Leto. The joint dedications can be explained by the mythological relationship of the two sibling gods. The fact that they were twins played an important part in the association of Artemis and Apollo in dedications, but their close relationship is rarely expressed through epithets (e.g. Delphinios/Delphinia, epekooi). Artemis and Apollo usually had different epithets in their joint dedications (for a list see p. 38).

209) C. WALLnER, Die Inschriften des Museums in Yozgat (Tyche, Sonderband, 6), Vienna, 2011: W. presents a catalogue of the inscriptions in the Museum of Yozgat; the inscriptions (mostly epitaphs) come from various sites in Galatia, Kappadokia, and Pontos. We highlight an unpublished epitaph from the area of Tavium (Imperial period, I.20*) with an interesting curse for those who open the grave: 'for whoever opens, may get

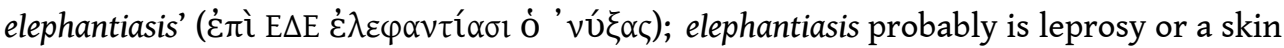
disease. In another ineditum, also from the area of Tavium, the deceased individual is designated

210) M. WIDMER, "Pourquoi reprendre le dossier des reines hellénistiques? Le cas de Laodice V", in F. BERTHOLET et al. (eds.), Égypte - Grèce - Rome. Les différents visages des femmes antiques, Bern, 2008, p. 63-92: W. examines the evidence for the benefactions of Laodike V, the wife of Antiochos III, to Greek cities and her cult in Iasos, Sardeis, and Teos. She argues that the queen did not exercize autonomous power but could take initiatives to offer humanitarian assistance to cities. Antiochos III introduced a high priestess for her dynastic cult, in order to strengthen the souvereignty of the reignung couple and secure that of their descendants.

211) H.-U. WIEMER, D. KAH, “Die phrygische Mutter im hellenistischen Priene: Eine neue Diagraphe und verwandte Texte", EA 44 (2011), p.1-54: Ed. pr. of a regulation concerning the sale of the priesthood of Meter Phrygie in Priene (2nd cent.). The priesthood was to be purchased by a woman for life. The priestess was exempt from the tax for herself and one slave. Her main duty was the offering of a sacrifice on the 12th of Artemision. On the 1st of Artemision, the priestess drew from the city the amount of 40 drachmas for the victims: a sheep for the Meter, a chicken for Pan, and two lambs for Hermes and Zeus. The perquisites of the priestess from this public sacrifice consisted in the skin of the sacrificed animals and half of the honorary portions $(\tau \tilde{\omega} v$ $\gamma \varepsilon \rho \tilde{\omega} \nu \tau \grave{\alpha} \dot{\eta} \mu i ́ \sigma \eta) ;$ the remaining meat was distributed among those who attended the sacrifice. She was obliged to provide cakes ( $\varepsilon \lambda \alpha \tau \rho \alpha)$ for the victims, things to be burnt $(\theta v ́ \alpha)$, grain corns (oủ $\left.\lambda \alpha \varsigma_{\varsigma}\right)$, and incense. In the case of private sacrifices, she received one third of the honorific portions. The priestess also supervised initiatory rites for

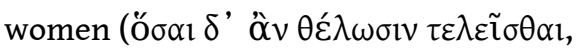




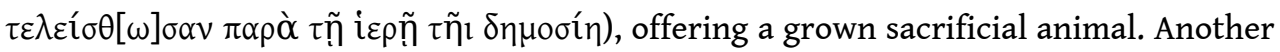
exclusive right of the priestess was the organization of an agermos together with other women, a gathering of donations, on the 4th of Artemision. From this offering, the priestess received one third of the honorific portions and the skin. The regulation also deals with the temenos of the goddess, obliging people to return to the sanctuary thalamai (possibly aediculae with the representation of Kybele). The priestess was

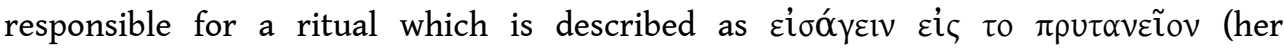
inauguration?, a sacrifice on the 12th of Artemision?) [the imperative Ei $\sigma \alpha \gamma \varepsilon ́ \tau \omega$ suggests that this was a ceremony that was repeated regularly; so, it cannot be the priestess' inauguration; it may be the inauguration of the civic magistrates on the first day of the year]. For this celebration, the city offered certain food items (grain, olive oil, honey, cheese). The expenses for the initiation of the priestess into her office

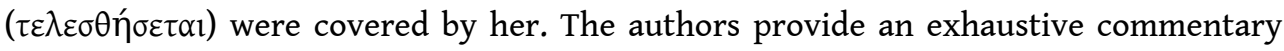
on the rituals, the institutions of Priene, and the cult of the Phrygian Mother/Kybele. In appendices they publish a dedication to the Phrygian Mother and republish with detailed commentaries the regulations concerning the priesthoods of Dionysos Phleos (I.Priene 174; LSAM 37) and Poseidon Helikonios (I.Priene 201-203; LSAM 38).

212) A. WOLICKI, “A Note on a Defixio from the Kerameikos", ZPE 180 (2012), p. 250-252

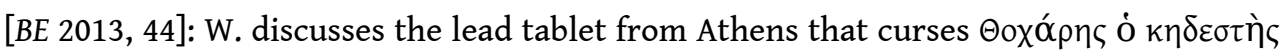

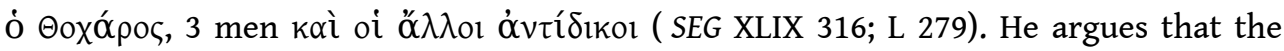
defigens did not curse 'Theochares, the in-law of Theochares' but Theochares and the in-law of Theochares, whose name was not inscribed, along with other individuals.

213) A. WYPUSTEK, Images of Eternal Beauty in Funerary Verse Inscriptions of the Hellenistic and Greco-Roman Periods, Leiden, 2012: This book offers a very useful survey of eschatological ideas found in grave epigrams of the Hellenistic and Imperial periods. Based on a very good selection of epigrams, presented in original and translation, W. discusses the following subjects: the perception of the dead as gods (especially apotheosis in the ether and among the stars); the designation of the deceased individual as ñ $\rho \omega \varsigma$; the motif of the marriage of the deceased individual (usually a girl) with a god; the perception of the deceased as chosen by the gods and as serving the gods. This book is a good example of how the systematic study of the epigraphic evidence can contribute to the understanding of religious phenomena.

\section{AUTHOR}

\section{ANGELOS CHANIOTIS}

School of Historical Studies

Institute for Advanced Study

Einstein Drive

Princeton, NJ 08540

achaniotis@ias.edu 